\title{
قبسسات مشرقة
}

في وصايا هؤهن آل فرعون كما وردت في سورة غافر حوار وتربية ودعوة

إعداد الدكتور الباحث

أبو بكر علي الصديق

أستاذ في التفسير وعلوم القرآن

بكلية التربية و العلوم الأساسية

جامعة عجمان للعلوم و التكنولوجيا

بدولة الإمارات العربية المتحدة

$$
\text { من هO }
$$


Y๑ฯ

rom 


$$
\text { بسم الله الرحمن الرحيم }
$$

المقدمة

الحمد لله رب العالمين الذي نزل شريعته لصلاح العباد ، ووفق عباده إلى سبل الرشاد، والصالاة والسلام على سيدنا ححمد خير الخلق وصفوة الحقى، وصاحب اللواء والسنة الغراء ، ورضي الله تعالى عن صحابته الطيبين وآل بيته الغر الميامين، والتابعين ومن تبعهم بإحسان إلى يوم الدين . أما بعد فِإن كِتَاب اللهِ فِيهِ نَبَاُ مَا قَبْلنا وَخَبَرُ مَا بَعْدنا، وَحُكُمْ مَا بَيْننا، وَهُوَ الفَصْلُ لَيْسَ

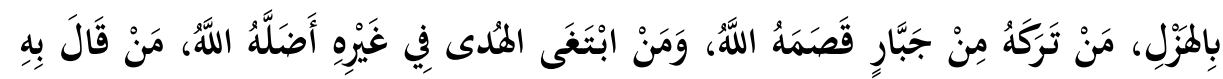

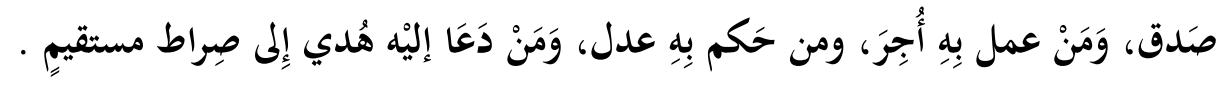

وبين أيدينا آيات بينات نظمت كأفا الدر المكنون، فيها كل ما تقدم من الأوصاف الكاملة للقرآن الكريم، صحيح أن هذه الأوصاف موجودة في كل آية ولكن قد لا تظهر إلا للغواصين في معاني القرآن الكريم، أما هذه الآيات التي بين أيدينا فهي دستور دولة، وقانون دعوة، ونظام جهاد ، وأسلوب حياة، وموعظة الدنيا والآخرة، وكل هذا ظاهر لكل ذي عقل وكل قاريء بصير، من خلال حوار دعوي تربوي، وسوف نرى بأعيننا كيف رتب لنا ربنا هذه المعاني واضحة جلية، وكيف رتب لنا المقدمات وما ينبني عليها من نتائج، وماذا كان مصير الطائعين وعاقبة المعاندين .

$$
\text { أهمية الموضوع }
$$

تأتي أهمية الموضوع من أهمية الكلام الذي لا يأتيه الباطل من بين يديه ولا من خلفه تنزيل من حكيم حميد ، فما من قصة ذكرها الله إلا استوفى فيها عظمة الأسلوب وروعة

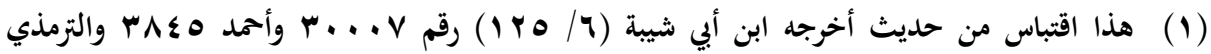

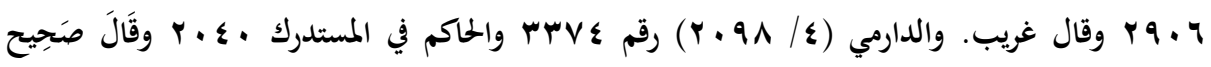
الإِسنَْاد وَلْم يخرجَاهُ وخالفه الذهبي . 
الأداء، واستوعب فيها البنية الأساسية وبث فيها الحكم والمواعظ ، وحشد فيها الأدلة

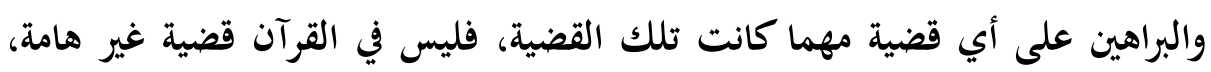
حيث القضايا كلها مترابطة ترابطا موضوعيا وبلاغيا من سورة الفاتحة إلى سورة

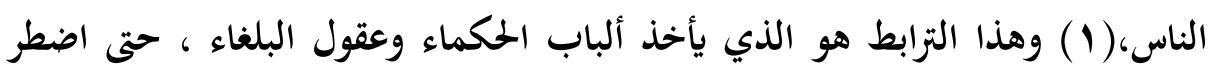

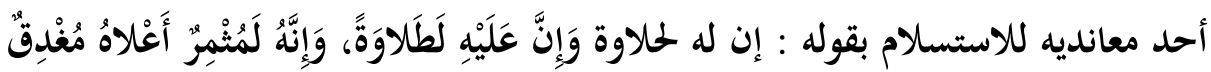

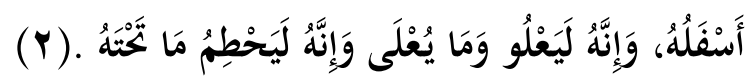
سبب اختيار الموضوع منذ زمن طويل جدا تستوقفني هذه القصة كلما قرأقا، خاصة عندما أتذكر النقاش

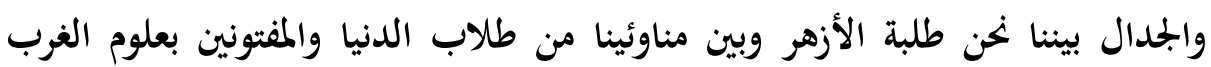
فأستمد منها قوة الحوار وثبات الدعاة، فأشعر بعزة وفخر لا ينهزمان، وأرى نفسي ثابتا ثبات الرواسي تنهزم أمامي الأفكار المدامة، وتتلاشى في عيني ترهات الملحدين، وتتخايل أمامي أصنامهم وهي تتحطم وتنهار ، ونظرياتم تتمزق وتتطاير . إزاء كل هذا تزاحت عندي الأفكار أن أكتب في هذه القصة وأعيد قراءتما من جديد وأتدبرها على ضوء ما استجد من أحداث، لعلنا نستطيع أن نخرج منها بدروس جديدة وعبر مفيدة، يرددها الأجيال على مدى القرون القادمة . خطة البحث أرى لزاما علي أن أقدم خطة تستوعب كل ما تقدم الإشارة إليه، وتحدد فصوله ومباحثه، وتبين كل ما تتضمنه هذه الآيات من معالم وتشتمل عليه من معان، ولذا سوف تكون الخطة مقسمة إلى تمهيد وفصلين:

(1) ينظر في ذلك كتاب البرهان في تناسب سور القرآن للشيخ أممد بن إبراهيم بن الزبير الغرناطي. وكتاب

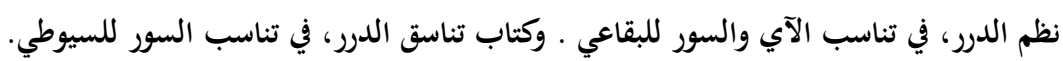

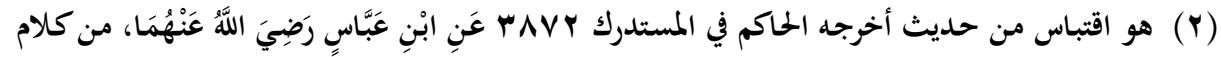

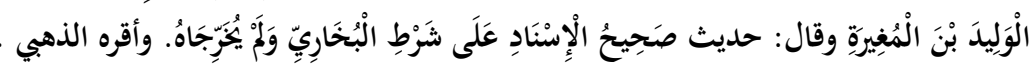


التمهيد : وفيه عرض للآيات التي تقص علينا قصة مؤمن آل فرعون مع تفسير المفسرين.

الفصل الأول: الحوار التربوي ـ وفيه مباحث

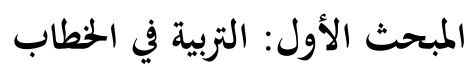
المبحث الثاني: التربية في كيفية بناء الدولة المبحث الثالث: التربية في تعليم أسس الجهاد الذي تقوم عليه الدولة الفصل الثائ : الحوار الدعوي ـ وفيه مباحث

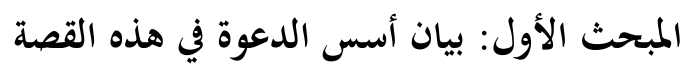

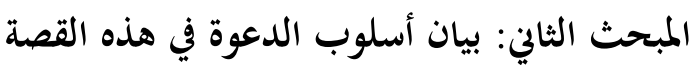
المبحث الثالث: بيان أسلوب الموعظة في هذه القصة الثمان الخاتمة: وفيها النتائج والتوصيات . لماتيكات الفهارس منهجي في الموضوع :

لم أتبع منهجا معقدا بل منهجي في العمل سهل سلس أعرض فيه آيات من الذكر

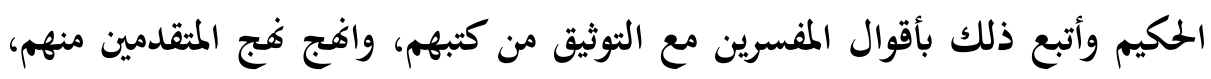

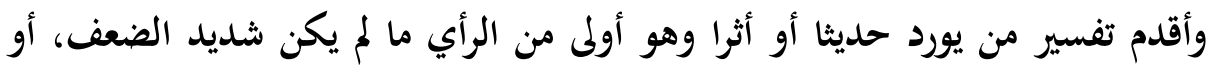

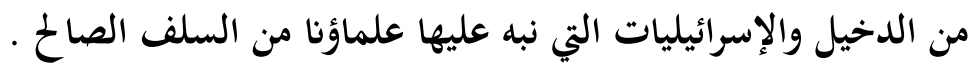

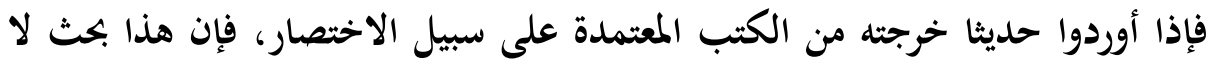
يحتمل التطويل، وبعد ذلك أقوم بالتحليل على حسب تلك الأحاديث والآثار وأقوال السلف والمفسرين القدامى الذين لم تختلط آراؤهم بالحداثة المزيفة وتحميل كتاب الله تعلى ما لا يحتمله . وحتى في العرض والتحليل الموضوعي لهذه القصة سوف ألتزم بالسنة الصحيحة ما وجدت لذلك سبيلا ، فإن لم أجد فعلى هدي الكتاب الذي فصل كل هل شيء والسنة التي بينت وأوضحت ووجهت ووضعت الثوابت حتى لا تزل بنا الأقدام. 
rq.

وسوف نرى بإذن الله عرضا جميلا يقدم الفكرة ويدعمها من الأصلين كتاب الله وسنة

المصطفى

والله الموفق وهو المادي إلى الصراط المستقيم، ومنه نستمد العون ونرجو منه السداد . 


\section{التمهيد \\ وفيه عرض للآيات في سورة غافر \\ التي تقص علينا قصة مؤمن آل فرعون \\ مع تفسير المفسرين}

ذكر الله قصة سيدنا موسى عليه السلام في القرآن كثيرا، ففي سورة البقرة ذكره مع بني إسرائيل وصعوده الجبل ثم عبادقم العجل، ثم العفو عنهم وإنزاله عليهم المن والسلوى، ثم سؤالهم رؤية الله جهرة، ثم سؤالمم العدس والبصل، ثم قصة البقرة، ثم ضربه بعاه بعصاه

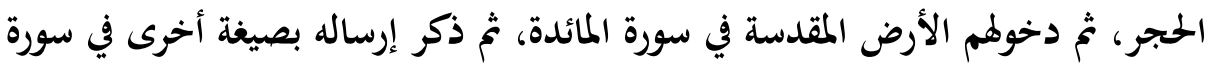
الأعراف وتحول العصا إلى ثعبان، وتحديه سحرة فرعون، وعقابهم بالطوفان والجراد والقمل والضفادع والدم ، وذكر كذلك اختيار سبعين رجلا، ثم كرر جانبا منها في سورة يونس وذكر قصة إسكاغم مصر، ثم كررها باختصار في سورة هود ، ومثل ذلك في سورة إبراهيم، وفي سورة الإسراء ذكر الآيات التسع، وفي سورة الكهف ذكر قصته مع الخضر عليه السلام، وذكر قصته باختصار في سورة ميم والمؤمنون والفرقان والنمل والنازعات، وفصل قصته في سورة طه والشعراء بأسلوب آخر، وفصلها بأسلوب آخر في سورة القصص وذكر فيها قتله النفس وخروجه إلى مدين ثم عودته رسولا مع أخيه هارون عليهما السلام، وزاد فيها قصة قارون، وفي سورة التحيم ذكر قصة زوجة فرعون، (1) وذكرت السنة قصة الماشطة (Y) وفي سورة غافر ذكر قصة مؤمن آل فرعون، بل إنما

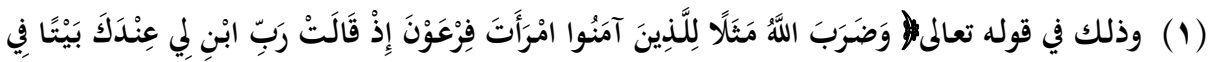

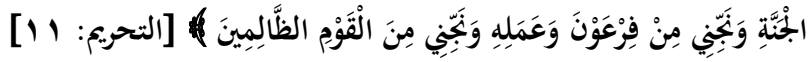

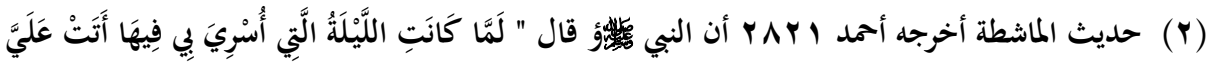

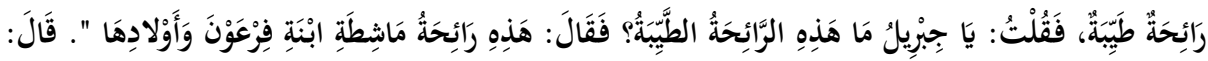

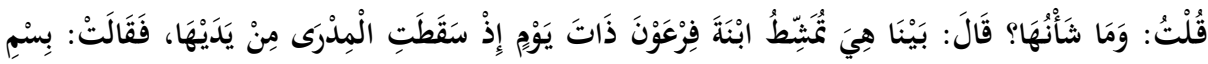

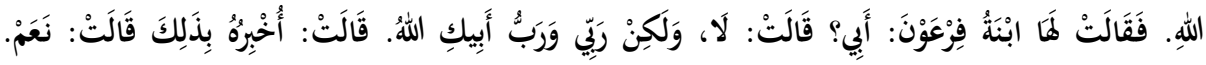


سميت بسورة (مؤمن) في كثير من نسخ المصحف، وعند كثير من كبار المفسرين (1) وهي القصة التي نريد التعليق عليها وتناولها بالتحليل ـ قال الله تعالم:

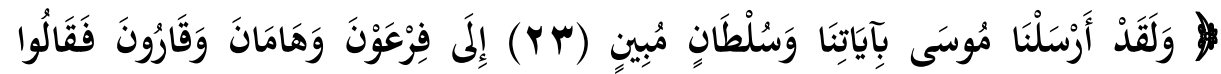

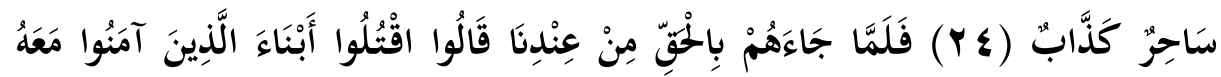

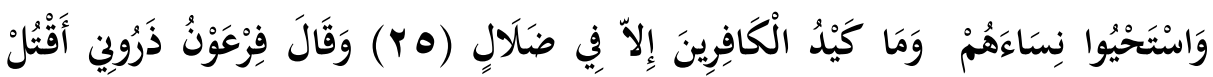

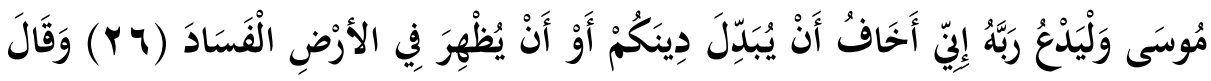

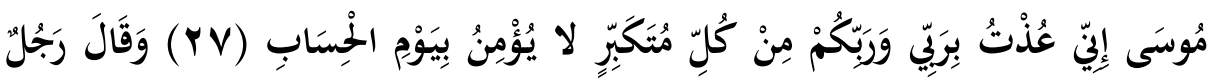

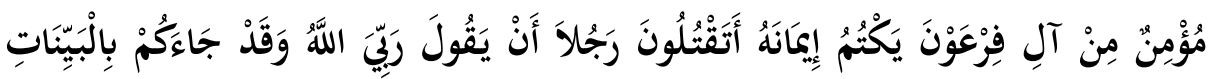

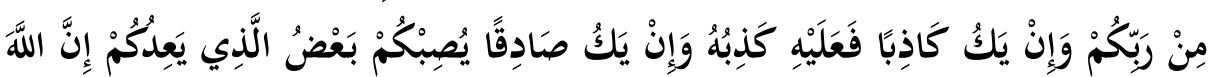

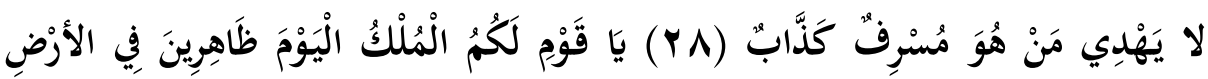

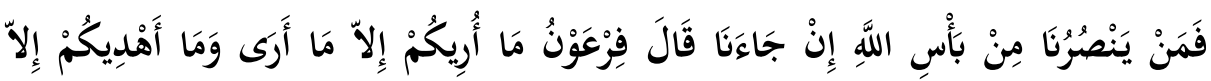

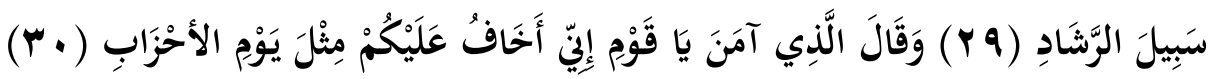

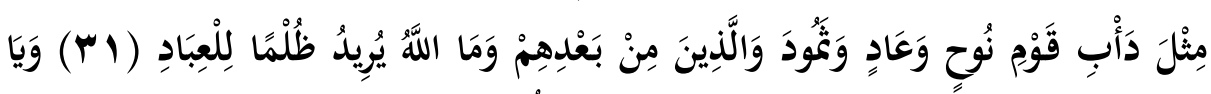

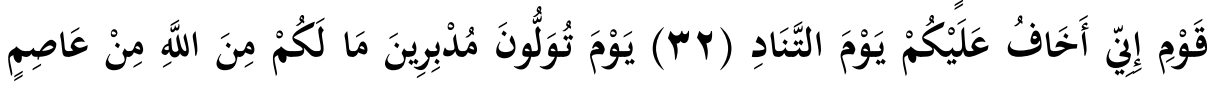

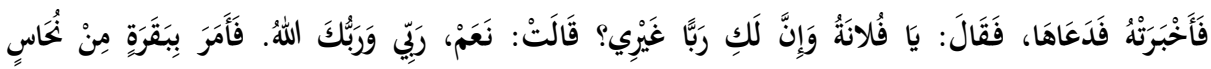

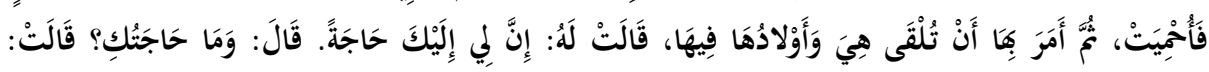

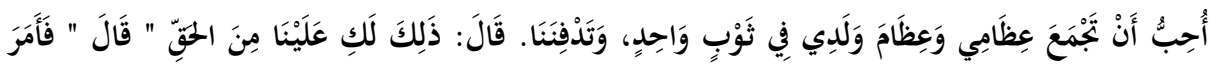

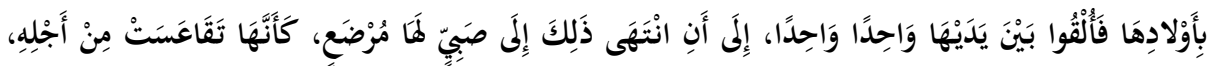

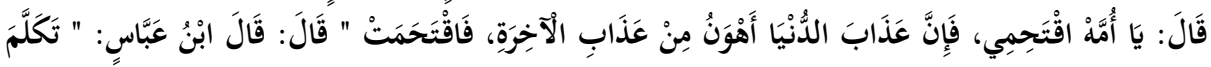

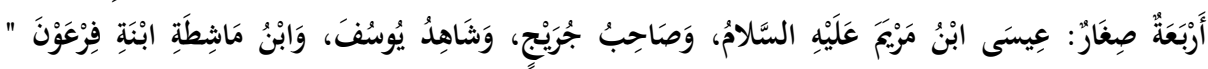

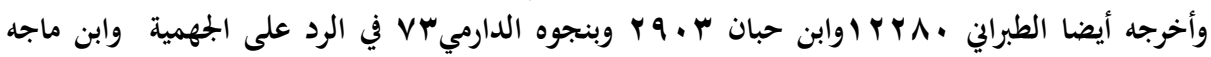

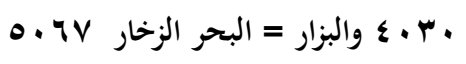

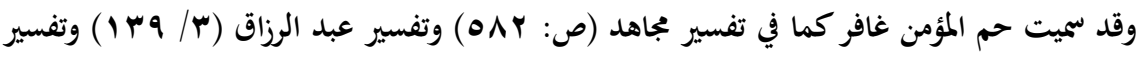




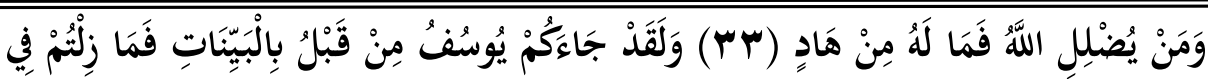

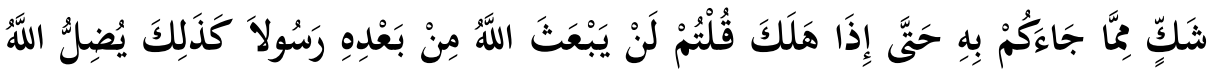

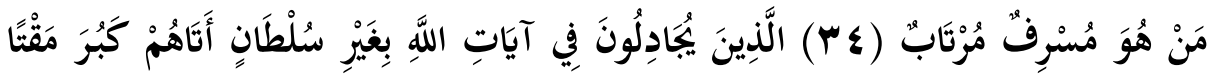

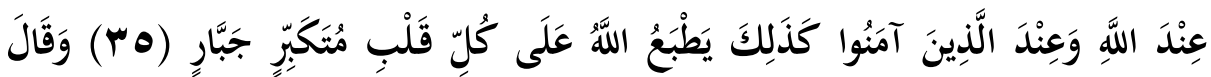

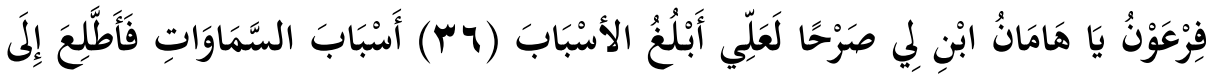

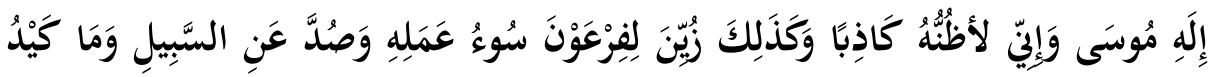

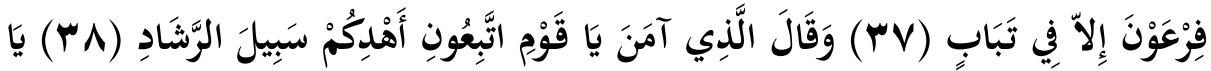

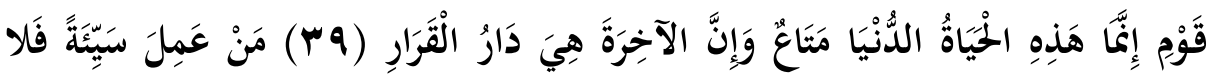

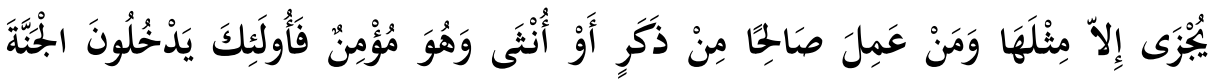

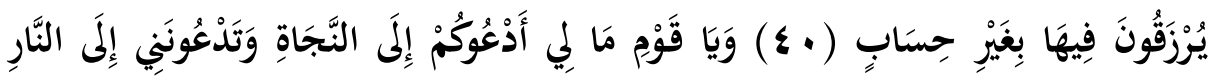

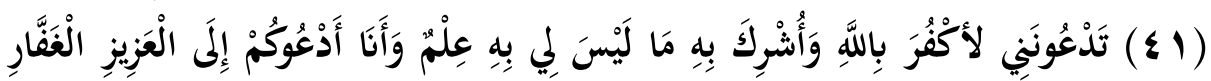

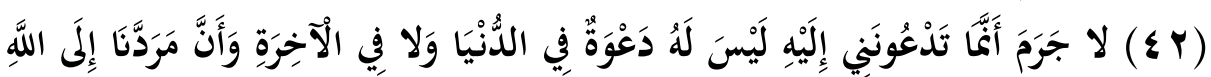

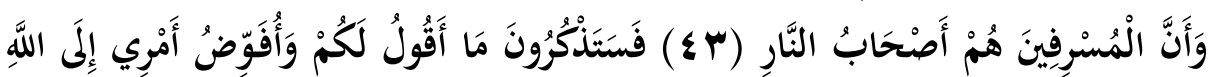

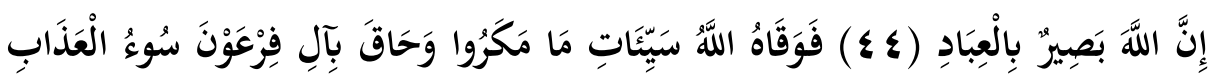

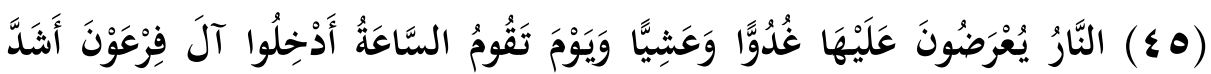

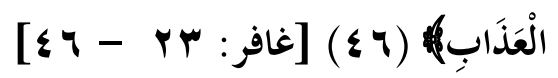

هذه هي الآيات التي تقص علينا قصة مؤمن آل فرعون، وقد قال المفسرون في قوله

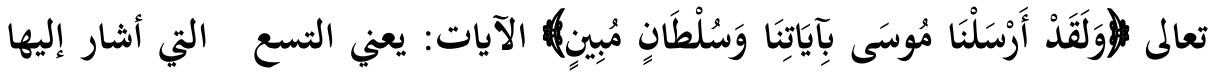

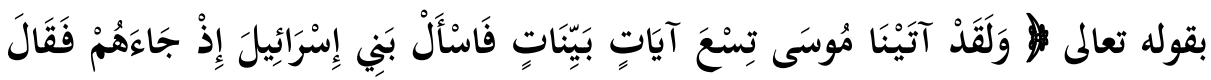

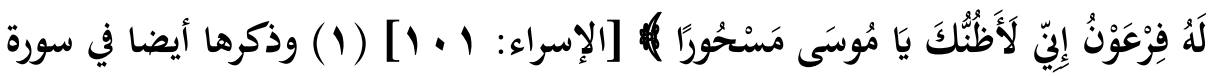




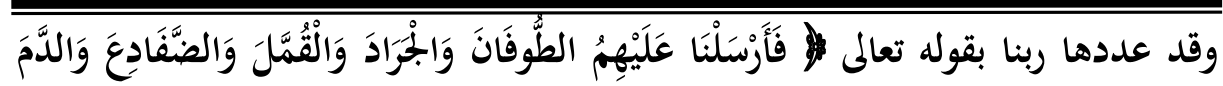

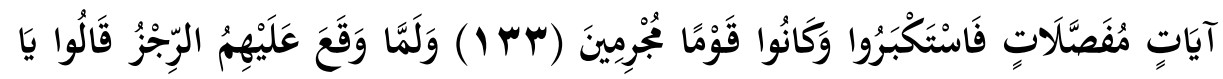

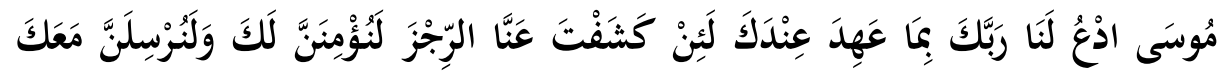

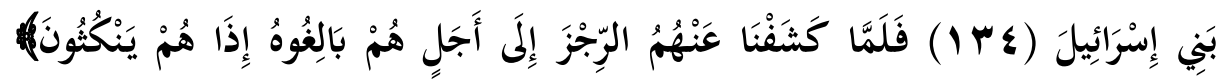

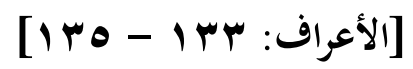

وعدها هنا خمسا مع سبق العصا واليد، وقد وردت في السنة مفصلة، وهي كما قال ابن

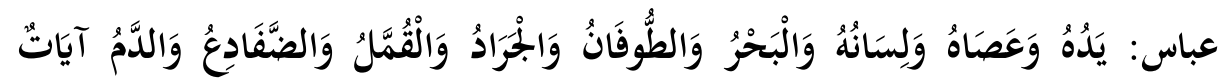

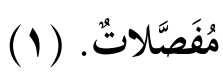

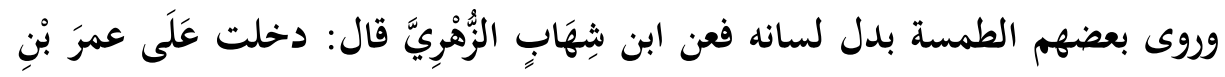

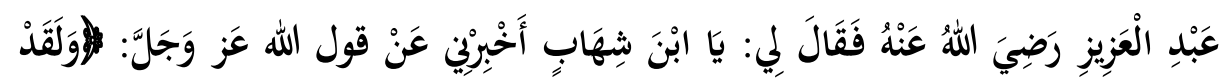

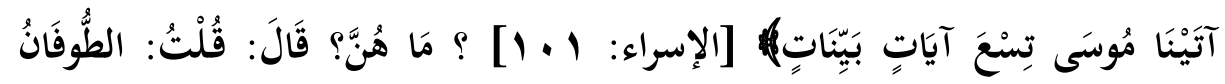

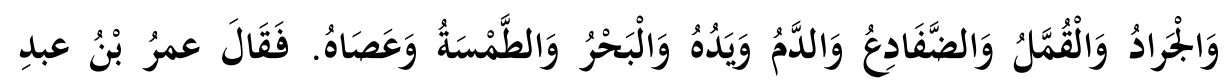

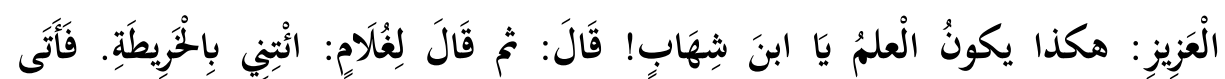

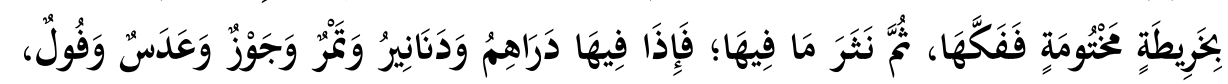

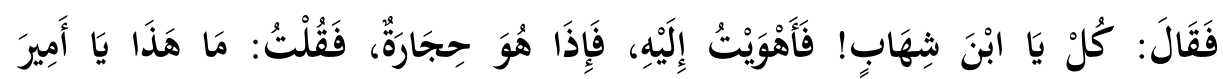

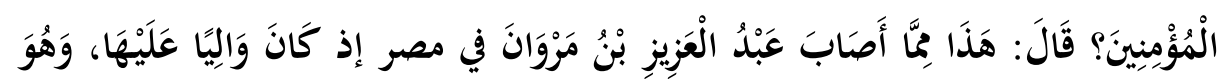

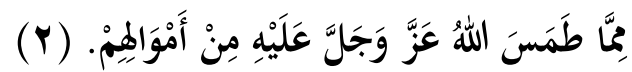

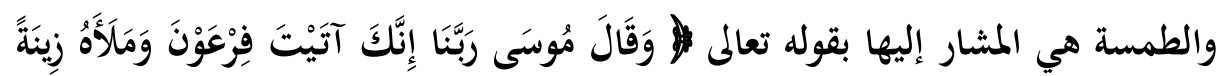

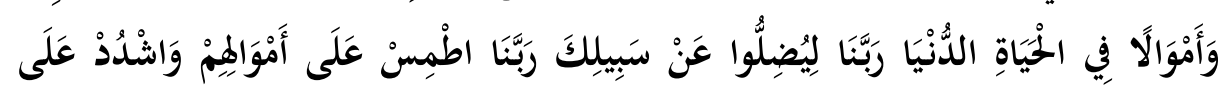

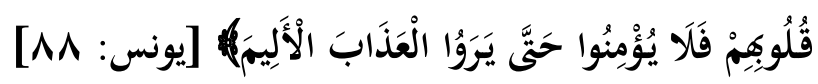

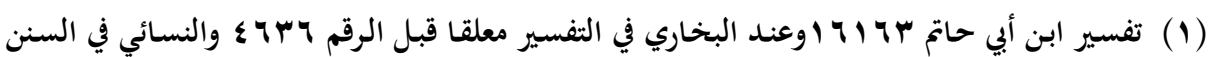

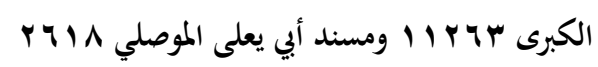

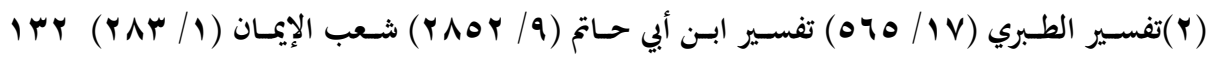




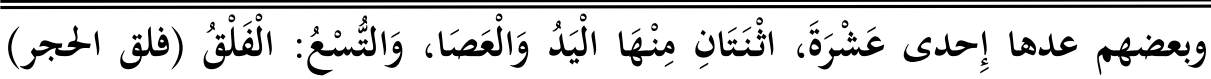

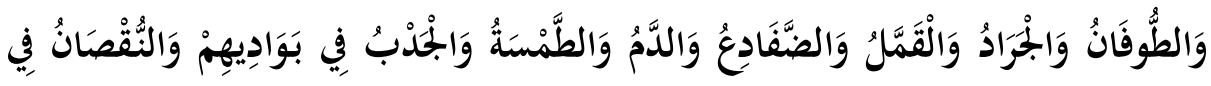

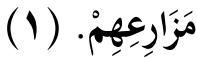

وعلى هذا تكونُ (في تسع آيات) بمعنى ( مع تسع آيات ) أوفي جملتها أو معها وتكون التسع هي: الفلق، والطوفان، والجراد، والقمل، والضفادع، والدم، والطمسة، والجلدب

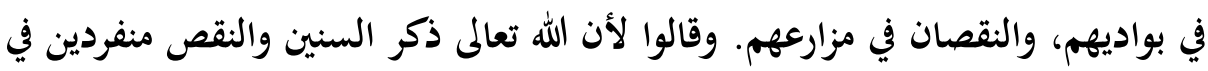

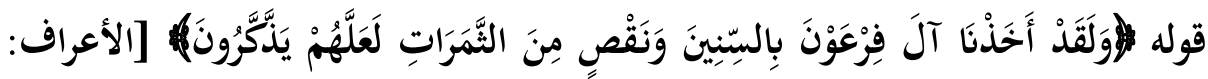

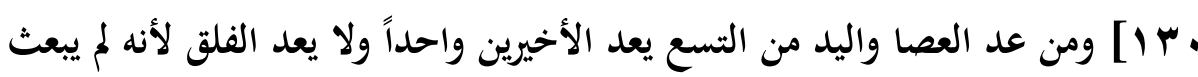

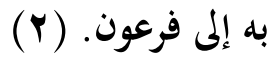

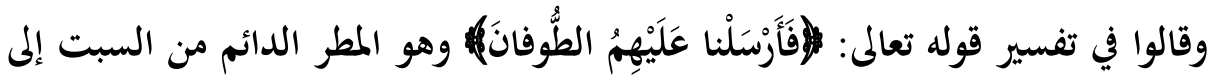

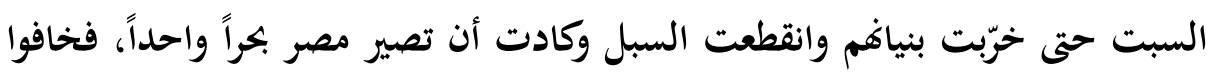

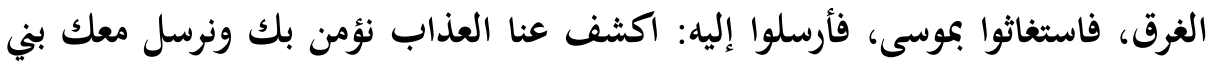

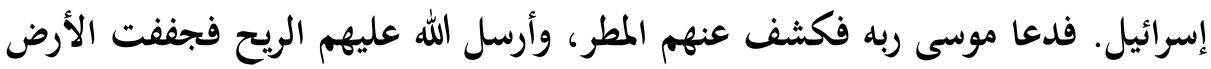
فخرج من النبات شيء لم يروا مثله بمصر قط. قالوا: هذا الذي جزعنا منا منه خير لنا ولنا ولكنا

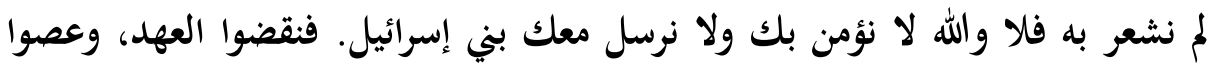

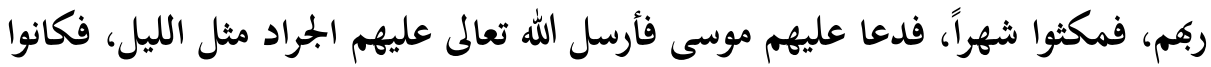

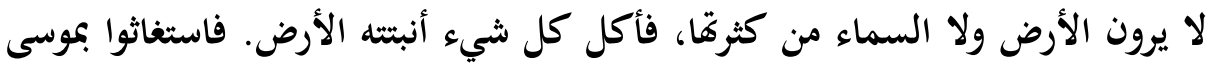

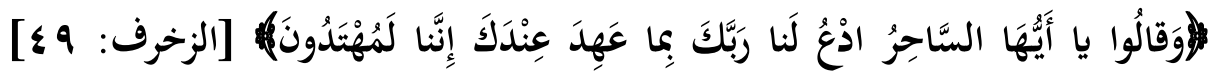

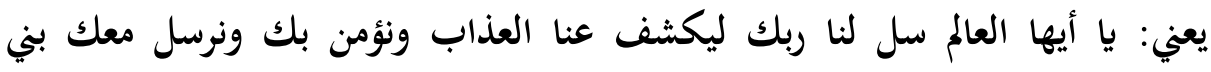

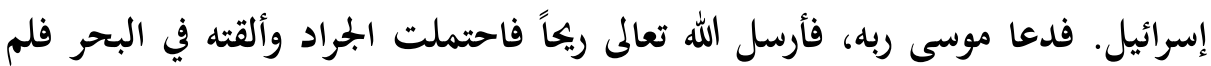

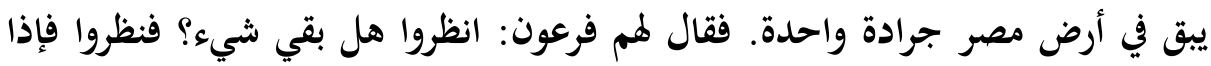

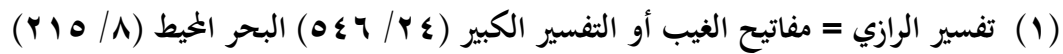

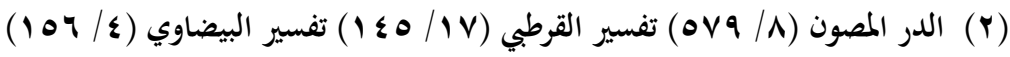


هو قد بقي لفم بقية من كلئهم وزرعهم ما يكفيهم عامهم ذلك. قالوا: قد بقي لنا ما فيه

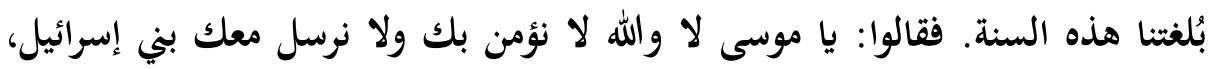

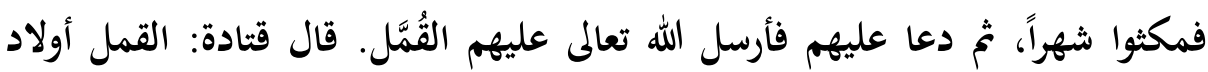
الجرادة التي لا تطير وهكذا قال السدي. وذكر عن أبي عبيدة أنه قال: القمل عند العرب الحمنان وهو ضرب من القردان، فلم يبق من الأرض عود أخضر إلا أكلته.

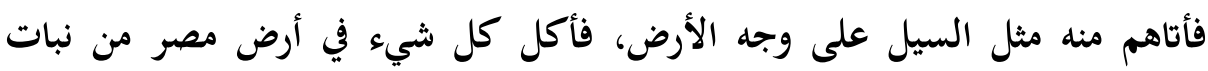

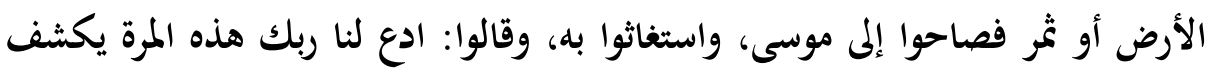

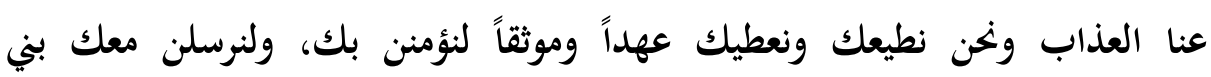

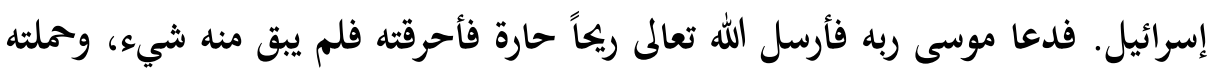

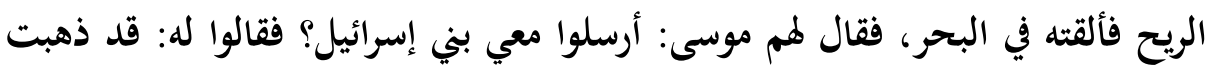

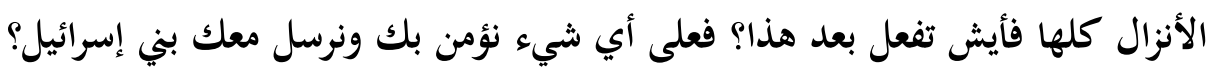

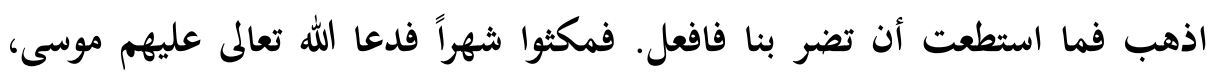
فأرسل الله تعالى عليهم آية وهي الضفادع، فخرجوا من البحر، مثل الليل الدامس،

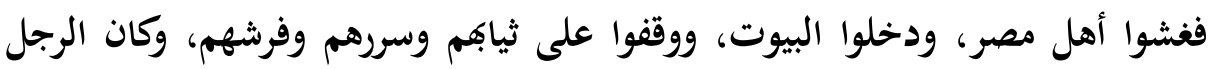

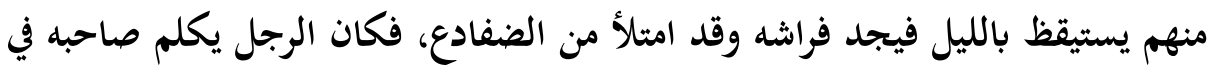
الطريق يجعل فمه في أذنه ليسمع كلامه من كثرة نعيق الضفادع. فضاق الأمر عليهم فصاحوا إلى موسى فقالوا يا موسى: لئن رفعت عنا هذه الضفادع لنؤمنن بك ولنرسلن معك بني إسرائيل. فدعا لهم موسى ربه فأذهب الله تعالى عنهم الضفادع. فقال لهم موسى: أرسلوا معي بني إسرائيل فقالوا: والله لا نؤمن بك ولا نوسي نوسل معك بني إسرائيل. فمكثوا شهراً، فدعا عليهم، فأرسل الله تعالى عليهم الدم، فجرت إنها: أغهارهم دماء، فلم يكونوا يقدرون على الماء العذب ولا غيره، وبنو إسرائيل في الماء العذب. وكلما دخل

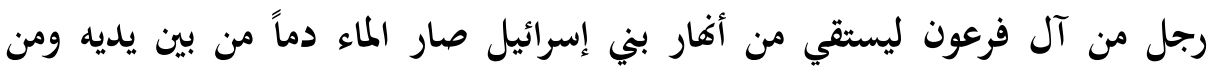

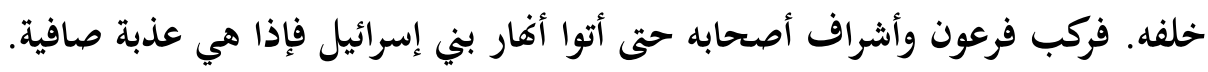
فجعل فرعون يدخل الرجل منهم، فإذا دخل واغترف صار الماء في يده دماً. فمكثوا 
كذلك سبعة أيام لا يشربون إلا الدم فمات كثير منهم في ذلك. فاستغاثوا بموسى فقال

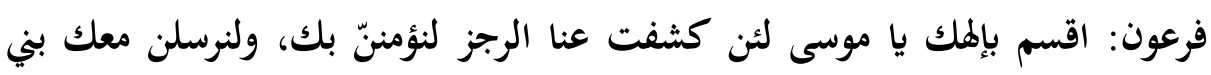
إسرائيل. فذعا موسى ربه فأذهب الله تعالى عنهم الدم، وعذب ماؤهم وصفا. فعادوا إلى

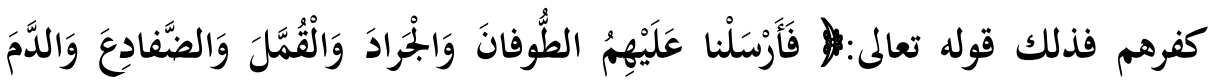

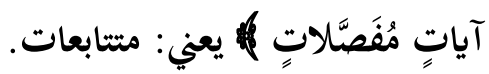
وقال الحسن وسعيد بن جبير وغيرهما: كانوا يعانون بين كل آيتين شهراً فإذا جاءت

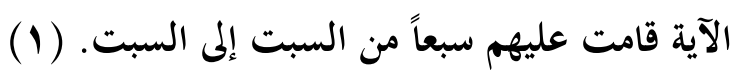

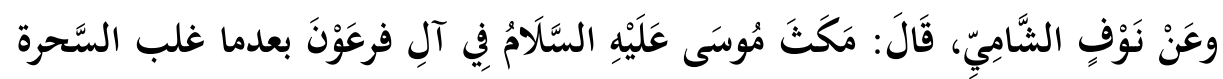

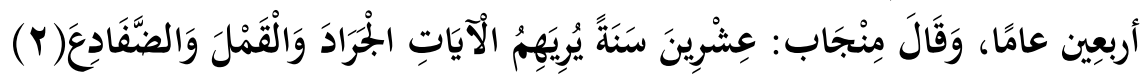

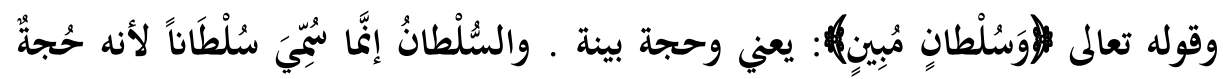

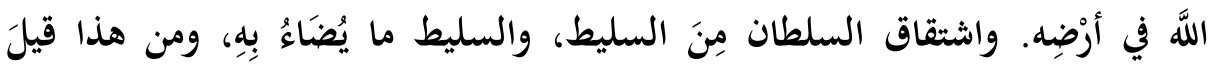

للزيْت سَليط. (r)

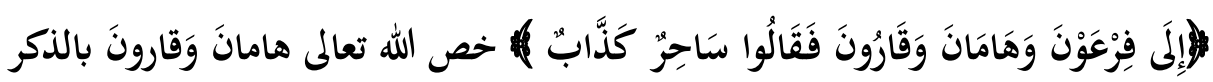

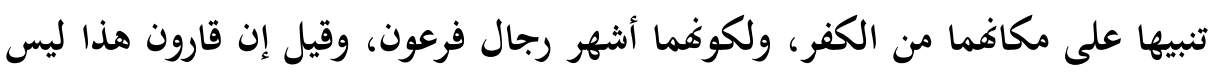
بقارون بني إسرائيل، وقيل هو ذلك، ولكنه كان منقطعا إلى فرعون خادما مستعينا معه.

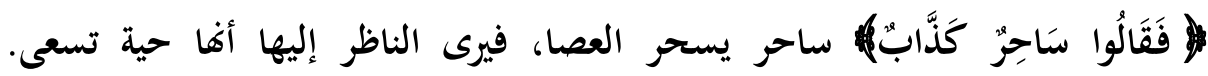

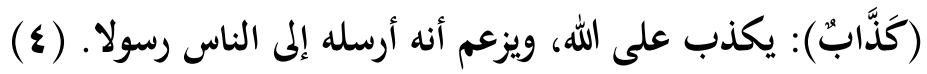

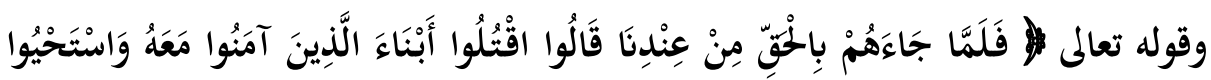

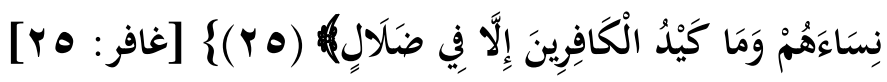

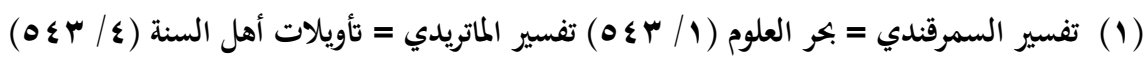

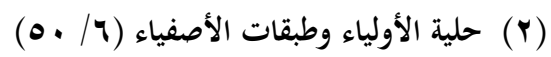

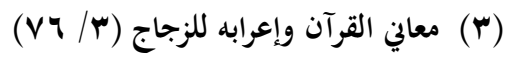

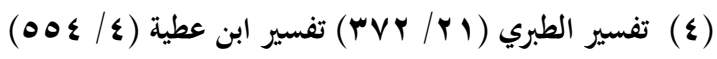




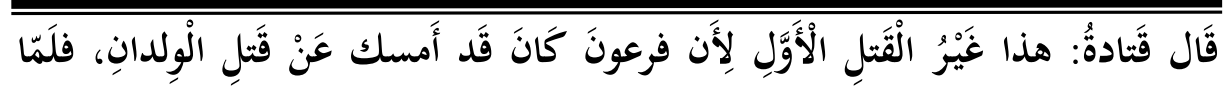

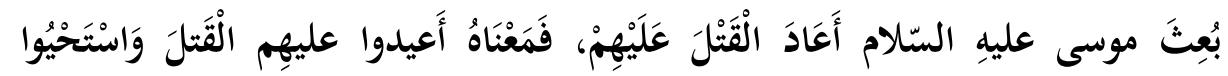

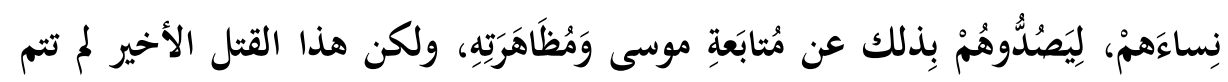

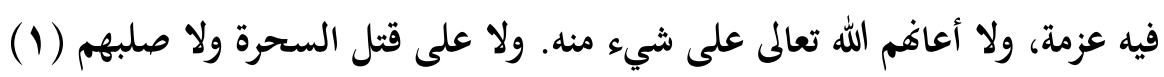

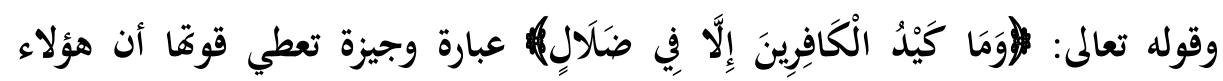

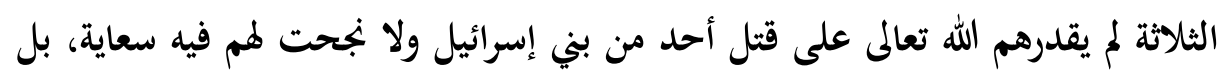
أضل الله سعيهم وكيدهم. (ץ)

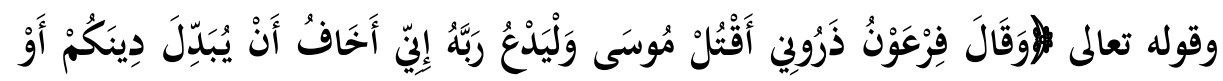

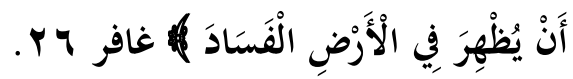

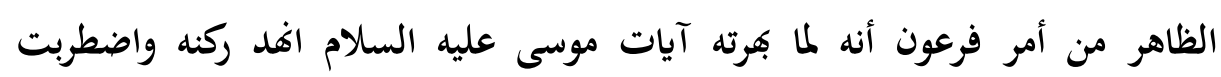

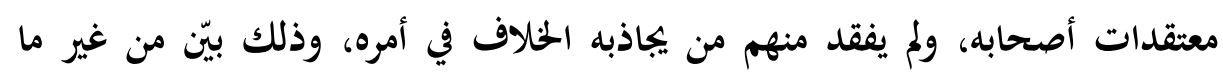
موضع من قصتهما، في هذه الآية على ذلك دليلان، أحدهما قوله: ذَرُورين فليست هذي هذه

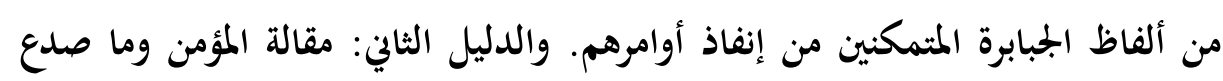

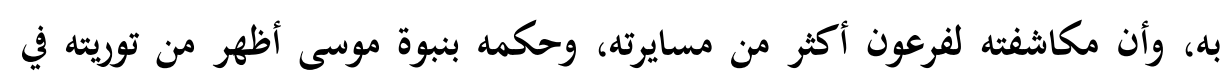

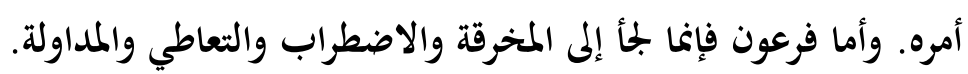

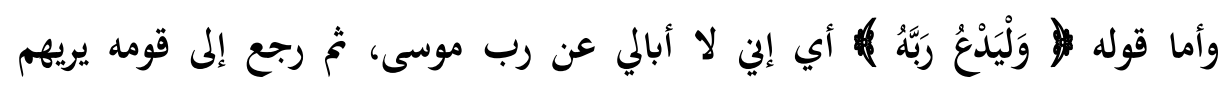

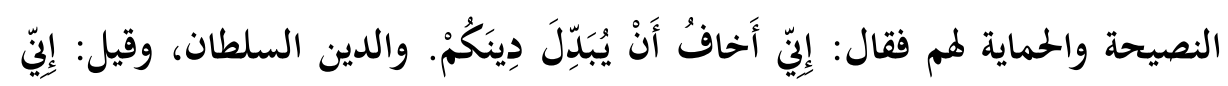

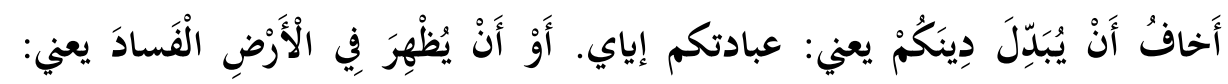

الدعاء إلى غير عبادتي. (ب)

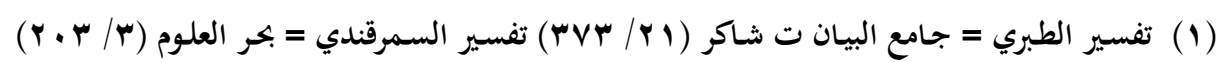

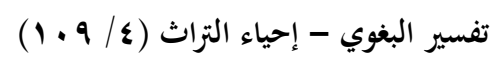

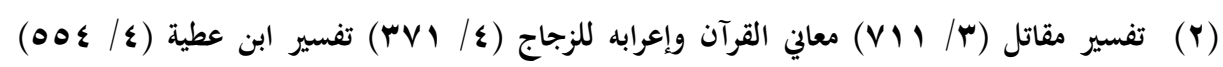

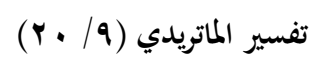

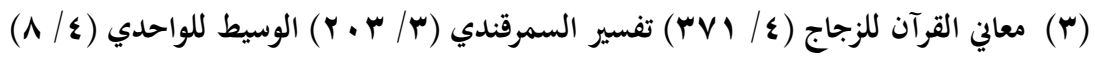




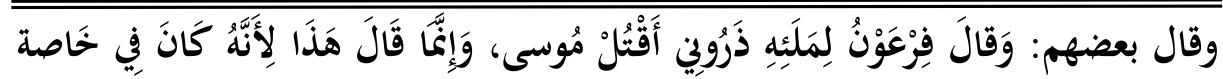

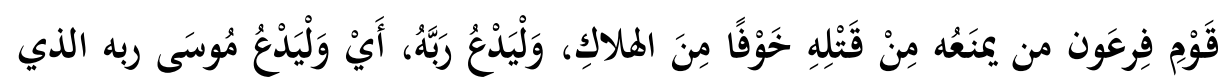

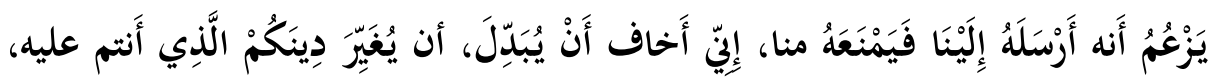

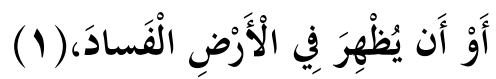

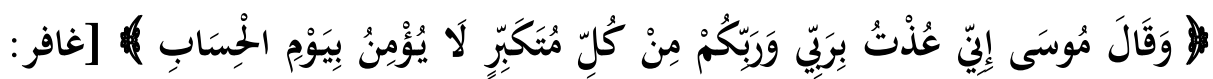
[YV

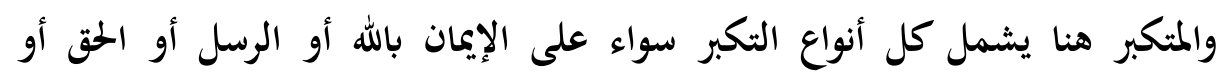
الاستماع للحقق . (Y) وإنما خص موسى عليه السلام الاستعاذة بالله ممن لا يؤمن بيوم الحساب، لأن من لم

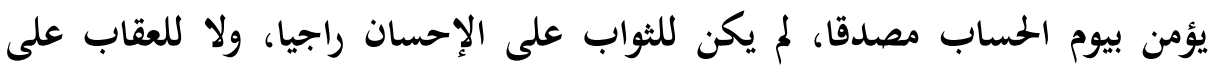

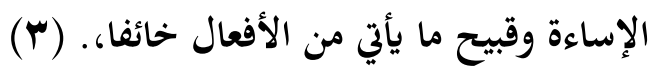

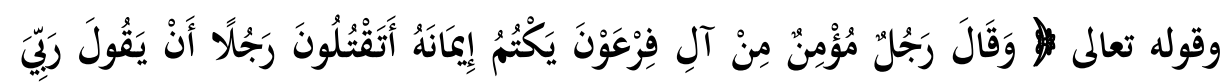

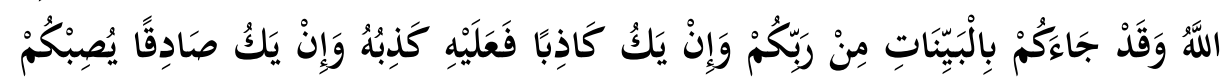

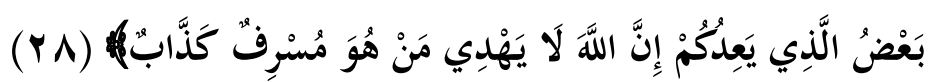

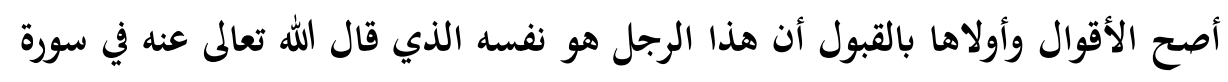

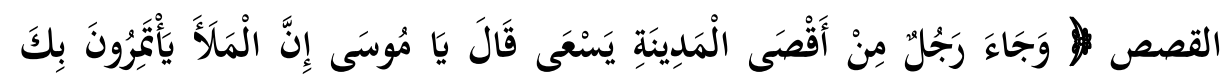

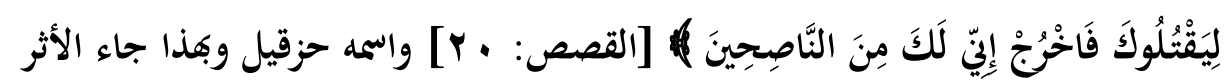

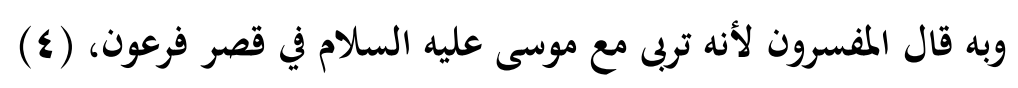

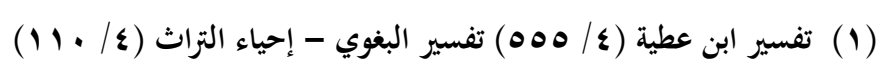

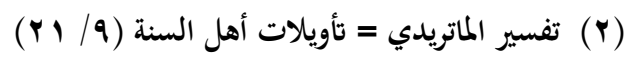

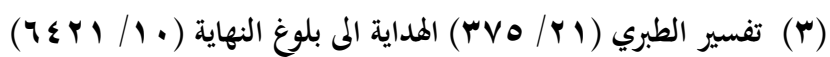

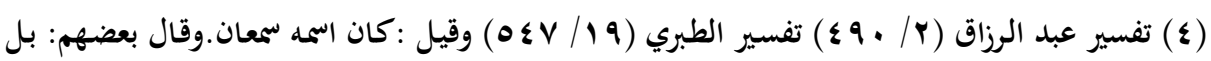

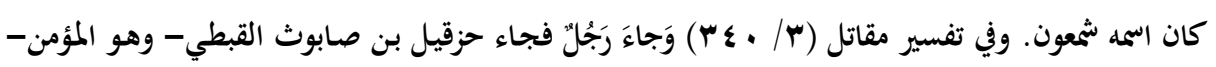
مِنْ أَقْصَى الْمَدِينَةِ 
وآمنت به كذلك زوجة فرعون التي تربى في حجرها وشاهدت الآيات، والتي ذكرها الله

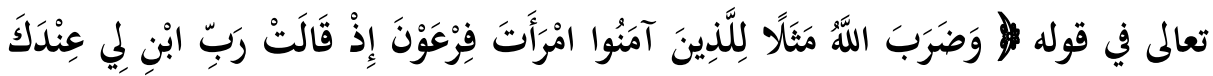

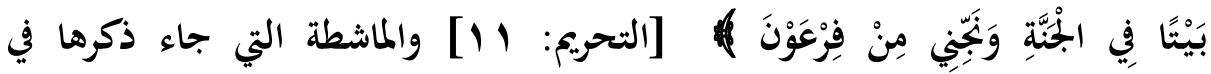

الأحاديث الصحيحة (1) بنئان

واختلفوا في هذا المؤمن، فقال بعضهم: كان من قوم فرعون، غير أنه كان قد آمن بموسى، وكان يُسِرّ إيمانه من فرعون وقومه خوفا على نفسه.

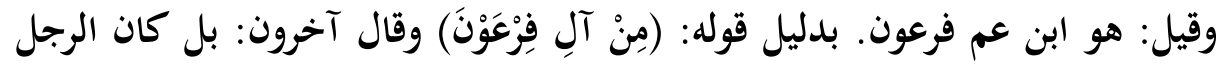
إسرائيليا، ولكنه كان يكتم إيمانه من آل فرعون.

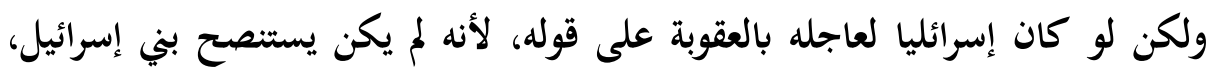

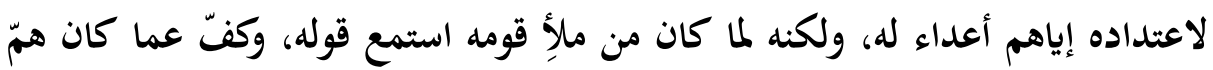

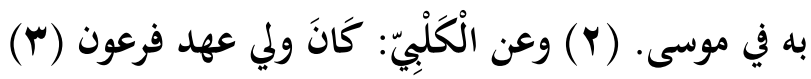

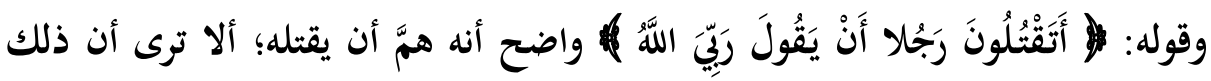

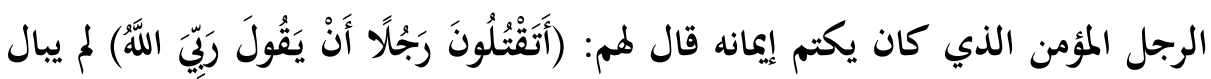
هلاك نفسه بإظهاره الإيمان بعد أن أعان به اللَّ موسى، ونفع له بما قال، واسته واستقبل

وورد ذكره في السنة ولفظه: "الصديقون ثلاثة حبيب النجار من آل ياسين وحزقيل مؤمن آل فرعون وعلى

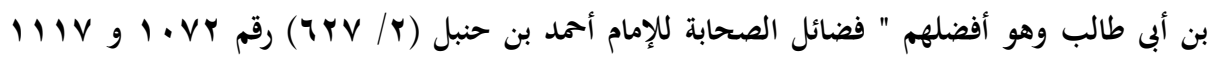

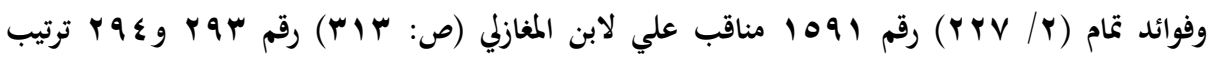

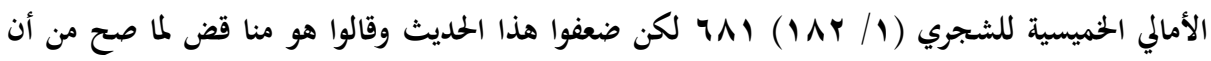

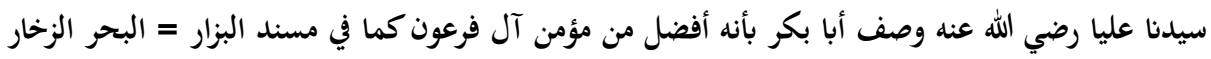

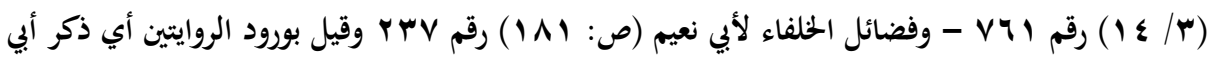

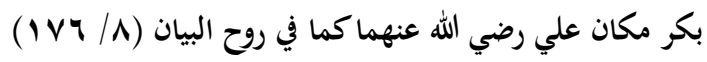

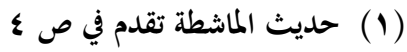

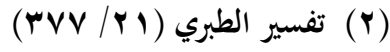

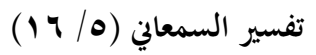


فرعون وقومه بما استقبل. (1) (1) وَقَدْ جَاءَكُمْ بِالْبَيْنَاتِ يَ) يقول: وقد جاءكم بالآيات الواضحات على حقيقة ما يقول من ذلك.

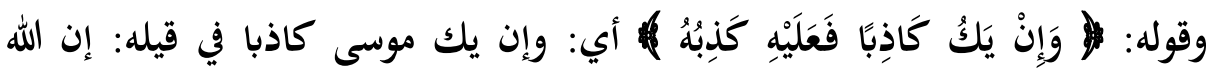

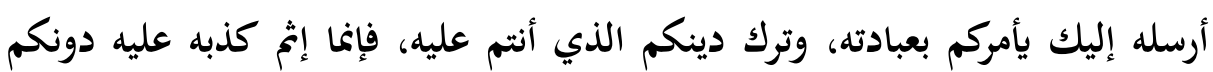

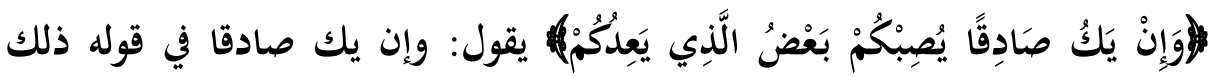
أصابكم الذي وعدكم من العقوبة على مقامكم على الدين الذي أنتم عليه مقيمون، فلا

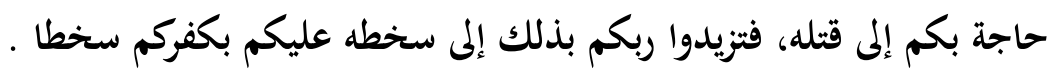

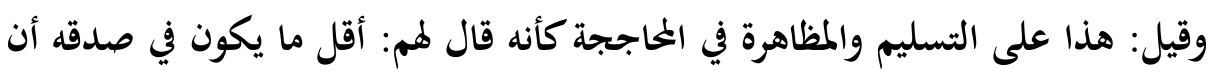
يصيبكم بعض الذي يعدكم، وفي بعض ذلك الك هلاككم.

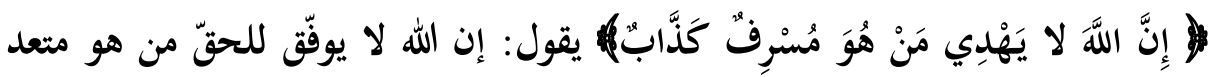
إلى فعل ما ليس له فعله، كذّاب عليه، ويقول عليه الباطل وغير الحقّ.

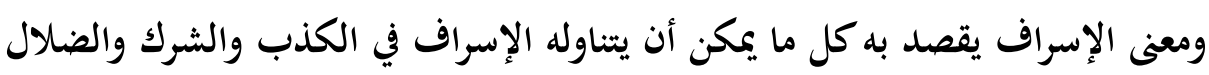
(r) والافتراء وقال آخرون: عنى به من هو قتَّال سفَّاك للدماء بغير حق.

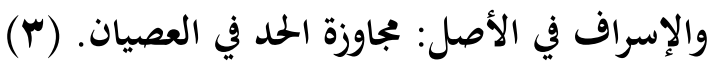

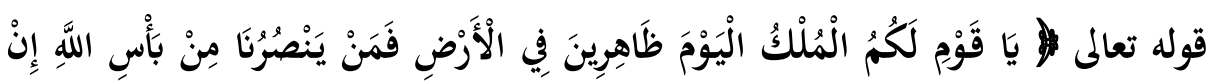

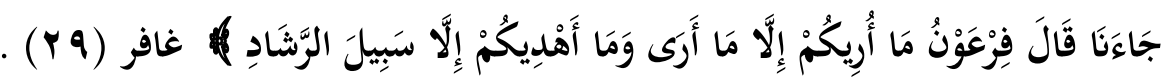
يقول مؤمن آل فرعون هذا على سبيل الرفق بهم وإظهار الموافقة لهم في الظاهر؛ يقول:

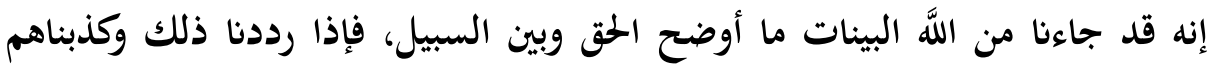
جاءنا بأس اللَّه جملة وعذابه، فمن يمنعنا عنه وينصرنا من عذابه إذا خالفنا أمره وتركنا

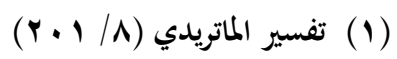

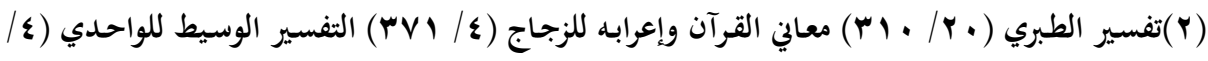

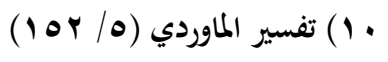

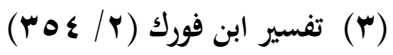


اتباع دينه؟ وهو تذكير لمم ووعظ لمم من جهة شهواتم وتحذير من زوال ترفهم ونصيحة لهم في أمر دنياهم.

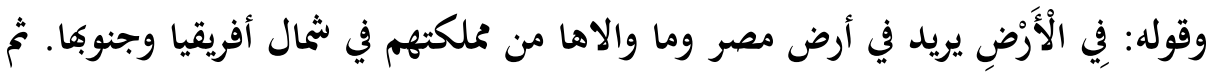
قررهم على من هو الناصر لهم من بأس الله، وهذه الأقوال تقتضي زوال هيبة فرعون،

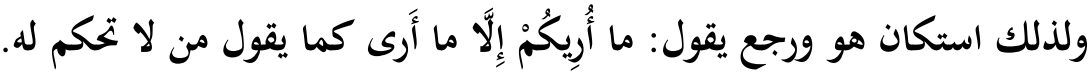

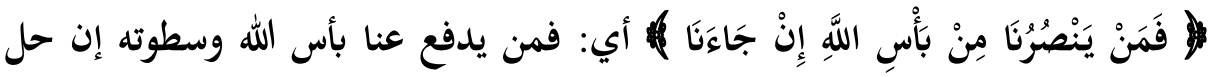
بنا، وعقوبته إن جاءتنا.

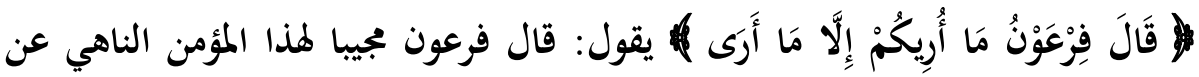

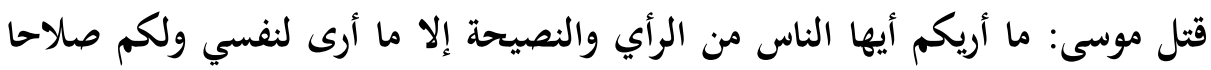

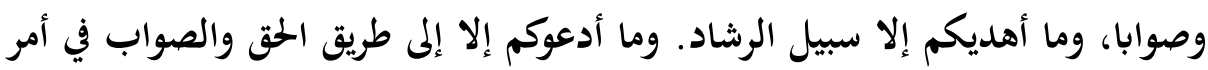

موسى وقتله، فإنكم إن لم تقتلوه بدل دينكم، وأظهر في أرضكم الفساد. (1)

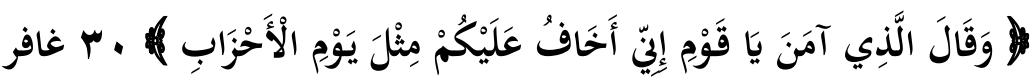

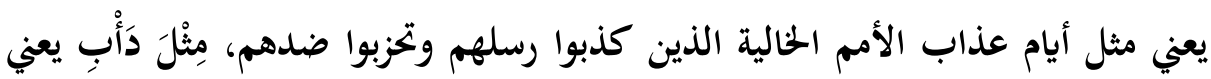

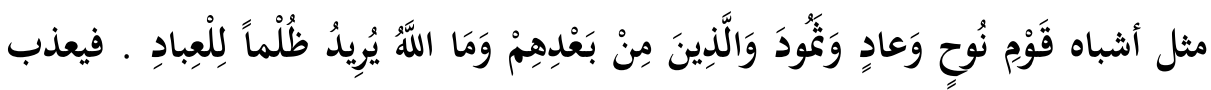
على غير ذنب، ثم حذرهم المؤمن عذاب الآخرة .

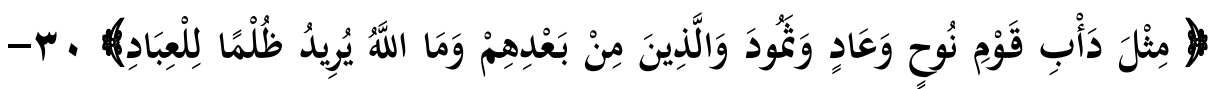

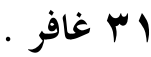

مثل يوم الأحزاب الذين تخزّبوا على رسل الله نوح وهود وصالح، فأهلكهم الله بتجرئهم عليه، فيهلككم كما أهلكهم. أي أخاف عليكم إذا أقمتم على كُفْرِكُ فينزل بكمم ما نزل بالأمَم السالِفَةِ المكذبَّة رُسُكَهم.

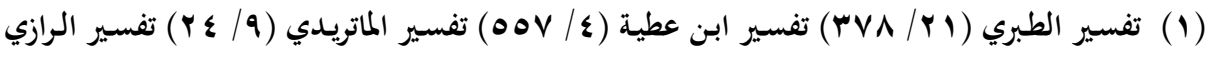

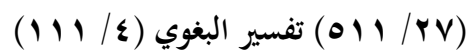




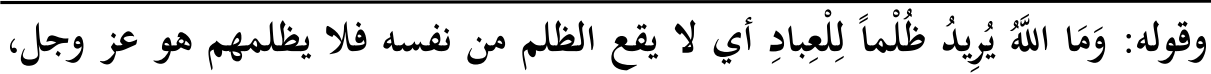

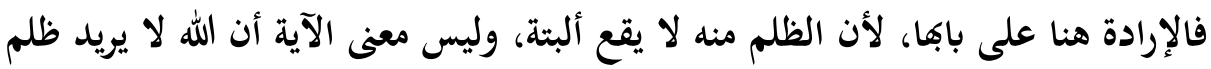

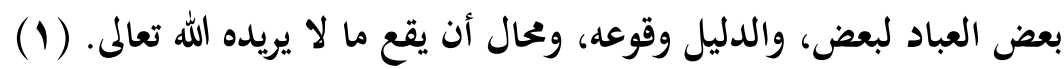

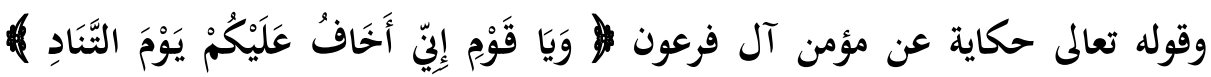

وقوله: يَوْمَ التَّنادِ معناه يوم ينادي بعض الكافرين بعضا ويناديهم الآخرون. سواء نداء

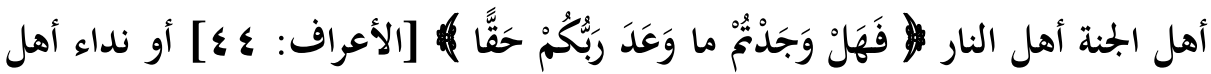

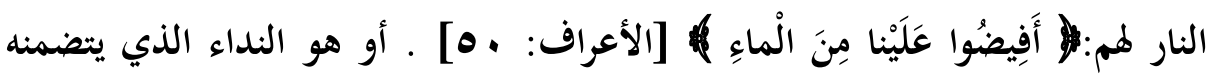

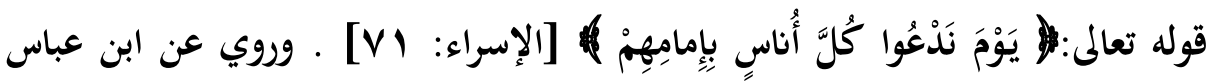
وغيره: هو التنادي الذي يكون بين الناس عند النفخ في الصور نفخة الفزع في الدنيا وأفم يفرون على وجوههم للفزع الذي نالهم وينادي بعضهم بعضا، كقوله تعالى:

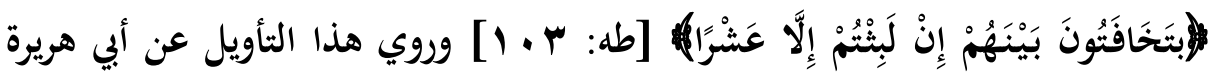

عن النبي صلى الله عليه وسلم. (؟) أو المراد بكل نداء في القيامة فيه مشقة على الكفار والعصاة، (ب) أو كالنداء الذي ييأس منه الكفرة 》يا أهل النار خلود بلا موتش ويتغيظون من نداء 》يا أهل الجنة

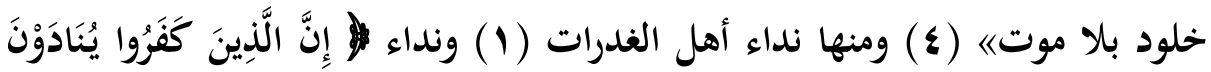

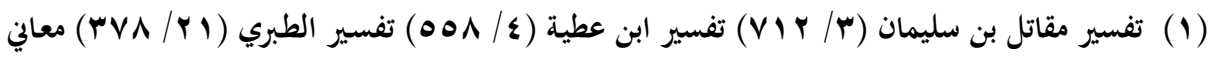

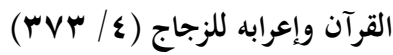

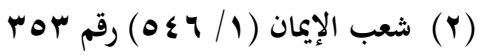

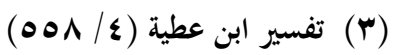

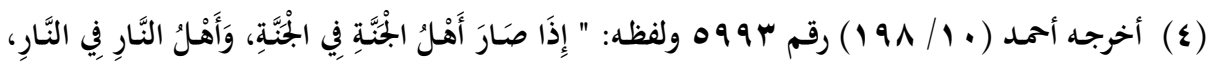

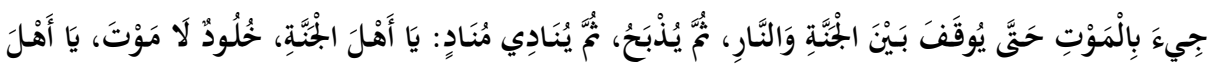

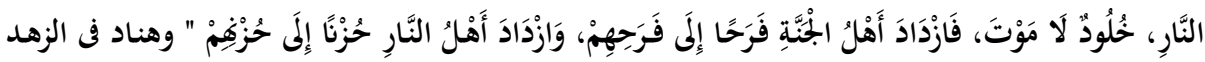

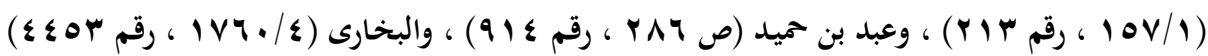




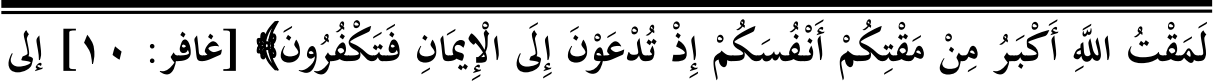

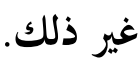

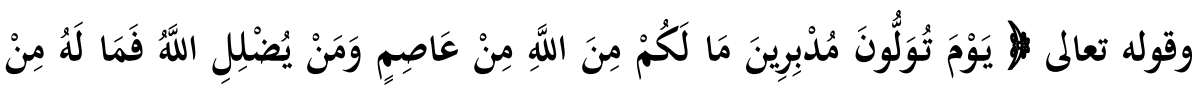

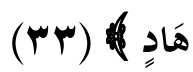
اختصر كثير من المفسرين هذا التولي والإدبار فقال مجاهد: يَعْنِ: فَرَرِيَنَ غَيَرَ

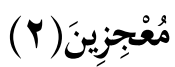

وقال مقاتل: يعني بعد الحساب إلى النار ذاهبين، ومثله عن عبد الرزاق (r)

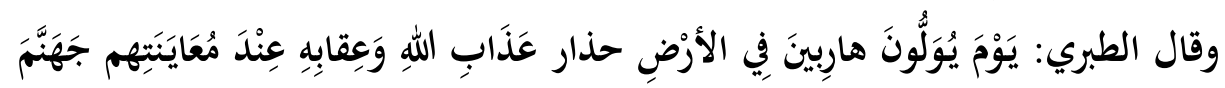

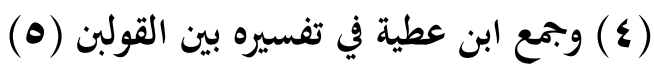

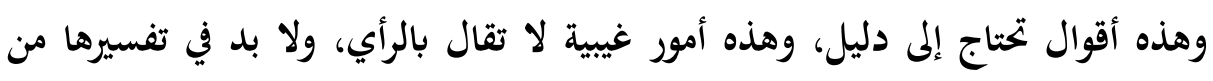

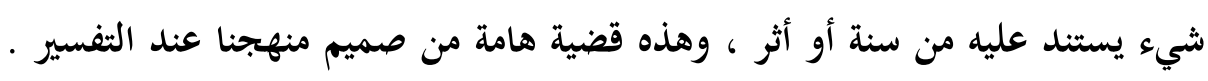

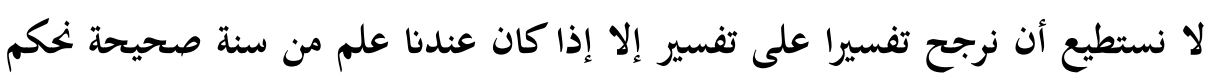

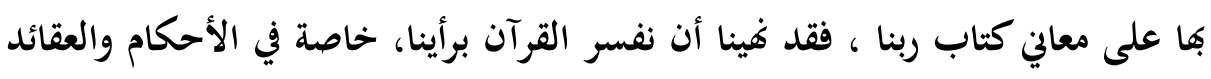
والغيييات .

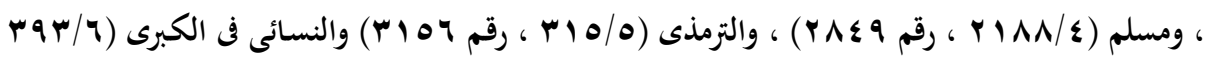

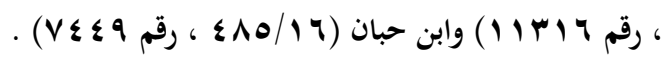

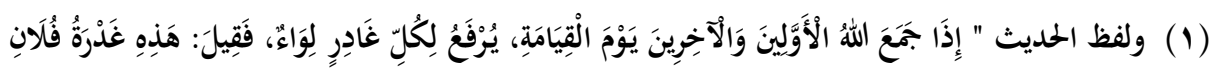

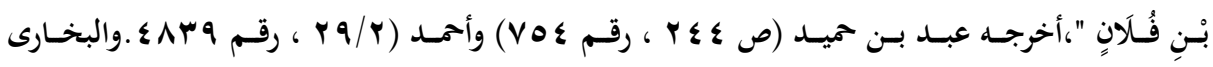

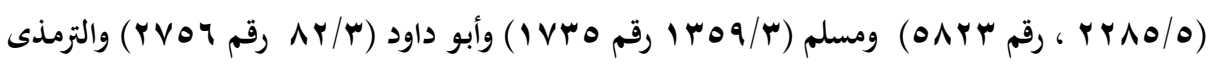

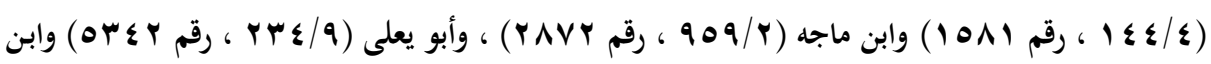

$$
\begin{aligned}
& \text { حبان (Y ( } 7 \text { ( }
\end{aligned}
$$

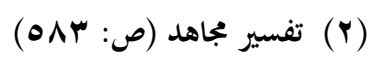

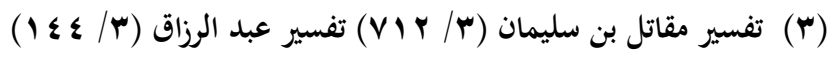

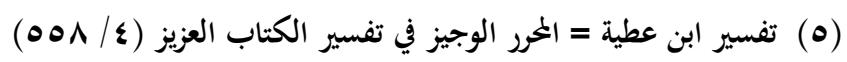

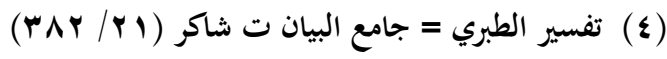


فالرجوع في هذا إلى المفسرين بالأثر، وقد رووا لنا حديثا بسند صحيح أن ذلك التولي والإدبار في المحشر من هول الفزع .

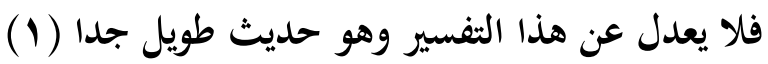

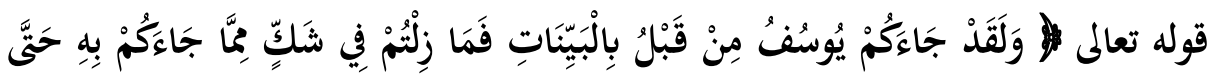

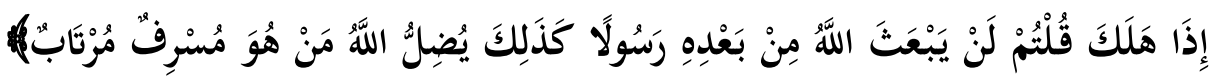

( ) ( سغافز)

قال المفسرون : ذكر مؤمنُ آل فرعون يوسفَ عليه السلام هنا لعلمهم برسالته (1) خروجا من الجحدال لكون الملك آمن به في زمنه، وإن كانوا في شك فالشك أفضل من

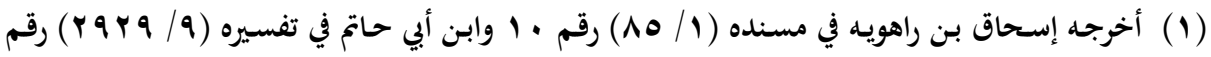

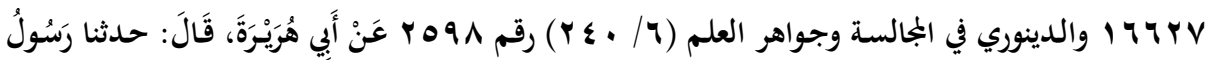

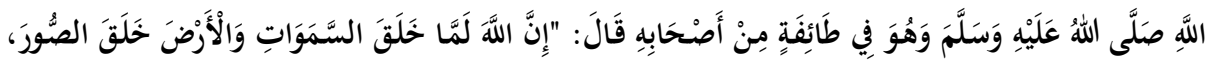

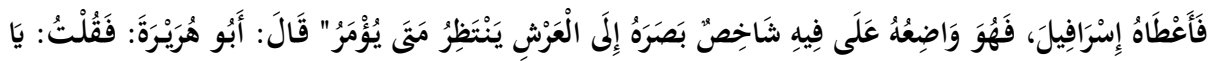

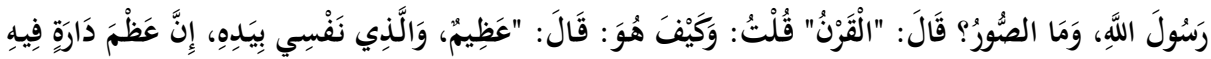

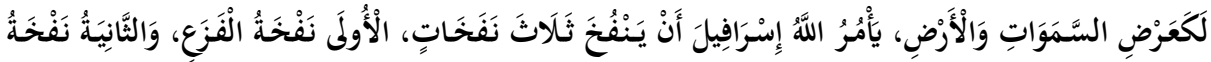

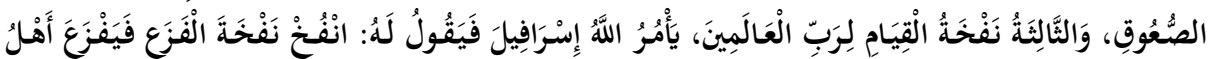

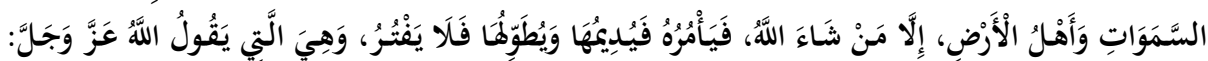

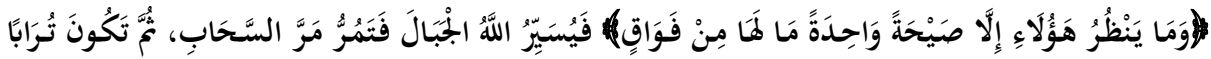

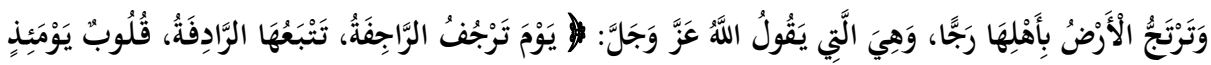

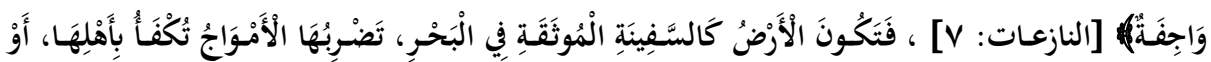

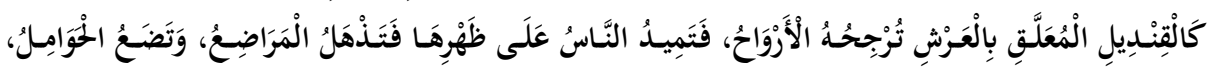

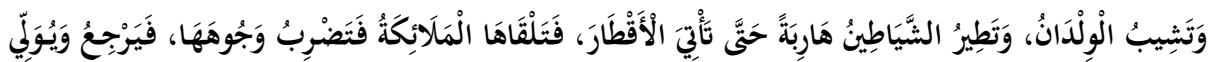

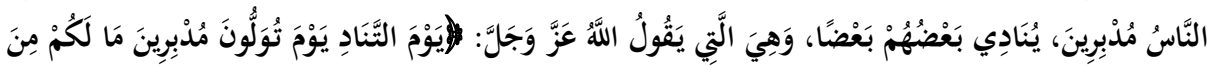

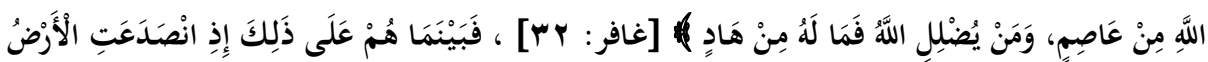

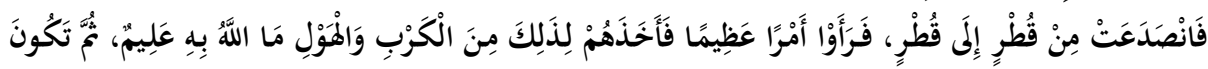

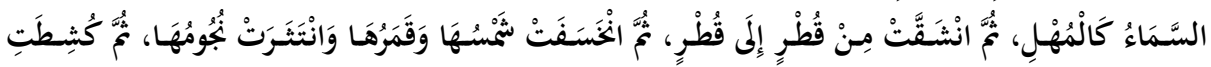

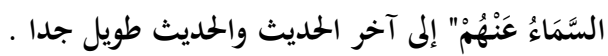


التكذيب، ولم يكن رآه المؤمن قط، وهم لم يووه ولكن نزل العلم مقام الؤية، وخاطبهم

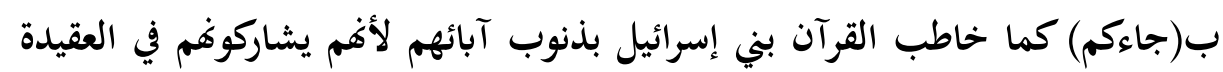
تلك .

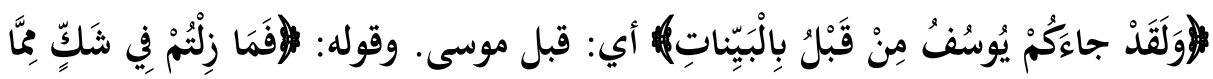

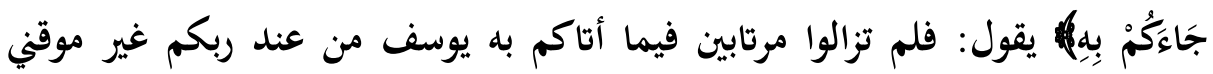

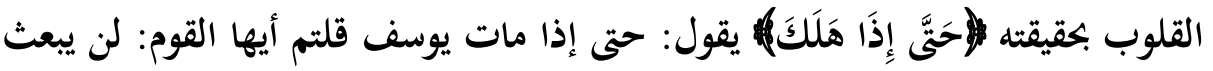

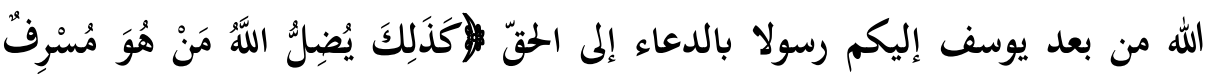

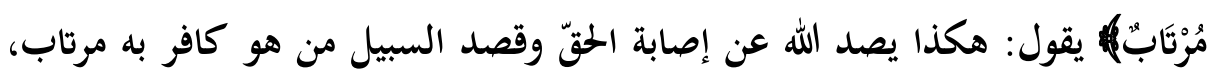

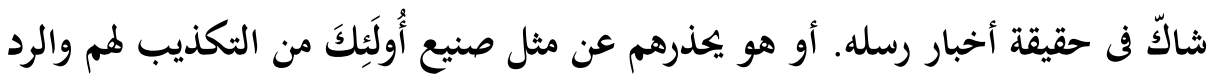

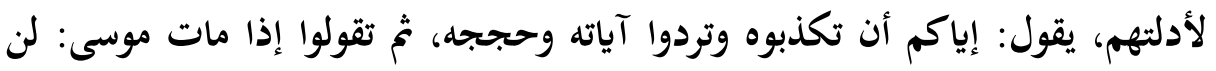

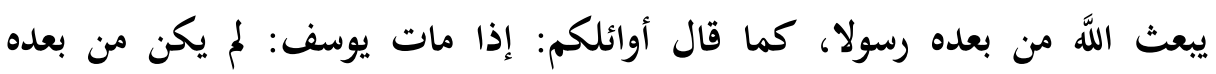

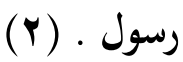

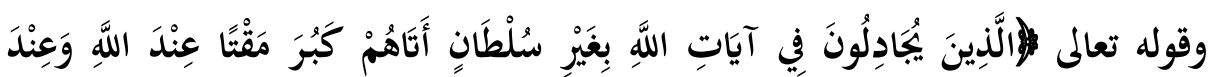

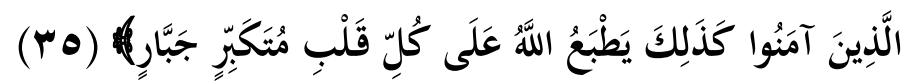

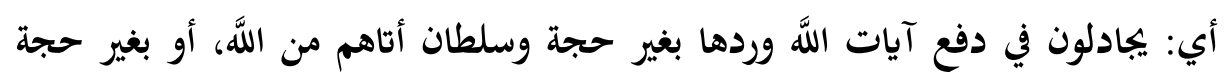

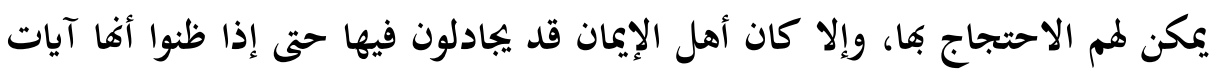
اللَّه آمنوا بها وأقروا بجا، لكن الوجه فيه ما ذكرنا، أي: جادلوا في دفع آيات اللَّ وردها

بغير حجة أتتهم.

(1) قال الزخشري:هو يوسف بن يعقوب عليهما السلام. وقيل: هو يوسف بن إبراهيم بن يوسف بن فئ

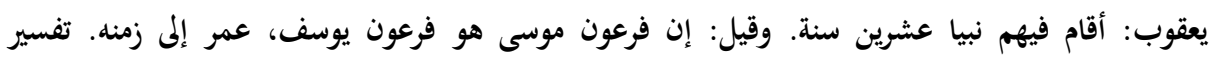

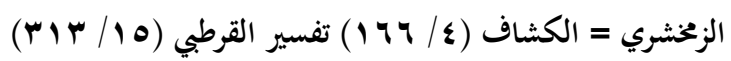

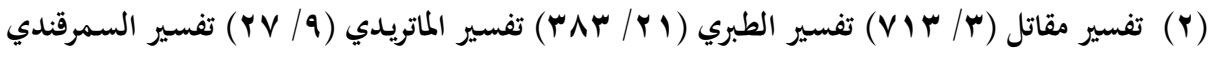


وقيل أي: وجدال الذين يجادلون كبر مقتاً وفاعل كَبُرَ كَذلكَ أي كبر مقتاً مثل

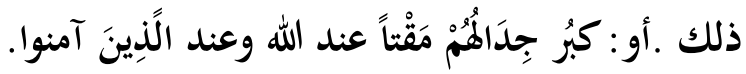

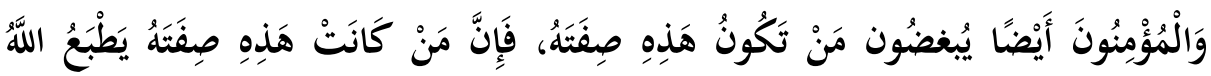

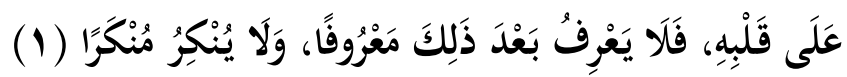
وقيل: كذلك يضلّ الله أهل الإسراف والغلوّ في ضلالفم بكفرهم بأقله، واجترائهم على دئى معاصيه، المرتابين في أخبار رسله، الذين يخاصمون في حججه التي أتتهم بها رسله ليدحضوها بالباطل من الحُجَج. (r)

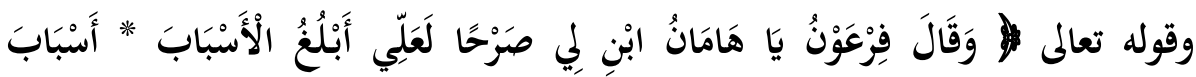

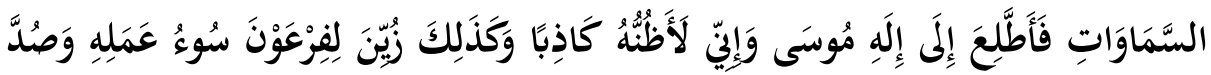

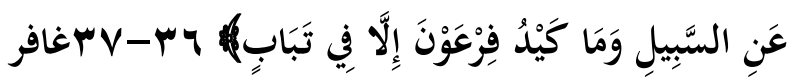

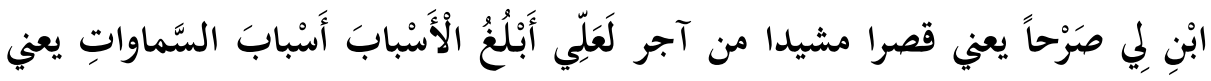

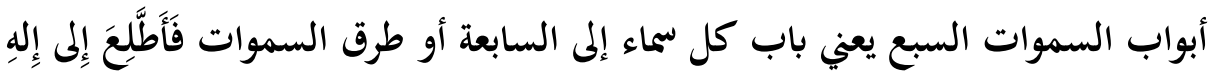

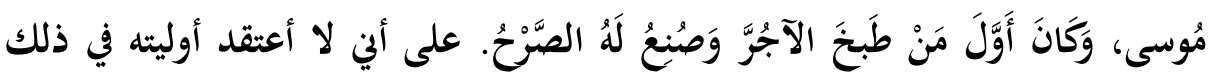

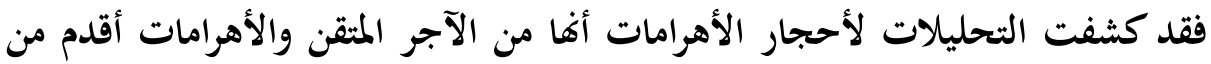
فرعون موسى بكثير. وكان من قصته وقصة ارتقائه أنه لما بُني له الصرح ارتقى فوقه، فأمر بِنُشابة فرمى بها نحو

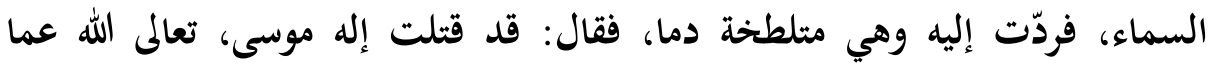

يقولون. (r) (ب)

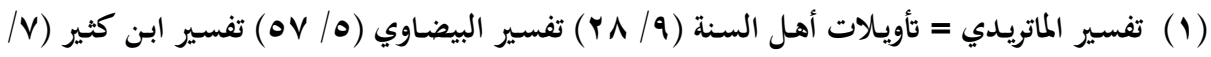

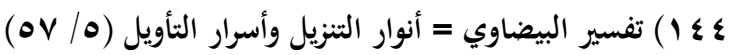

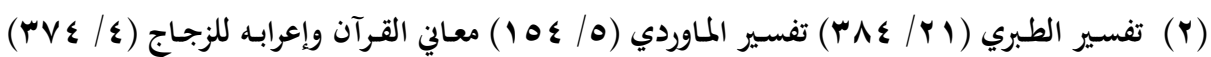

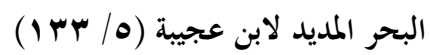

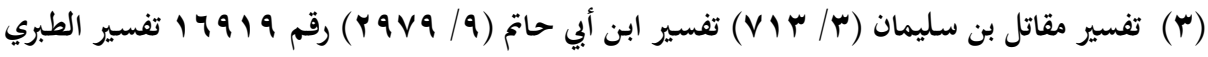




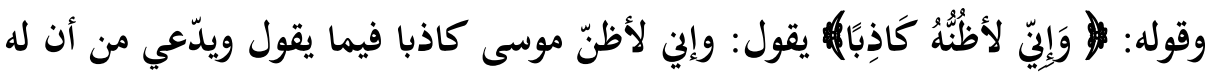

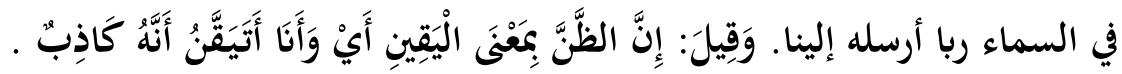

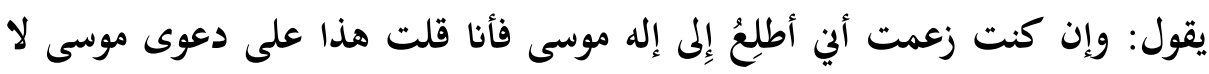
على أين على يقينٍ من ذلك. (1)

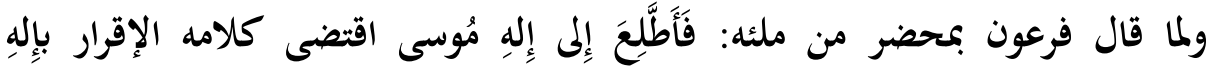

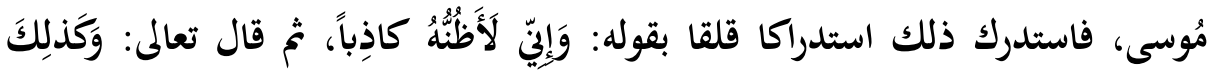

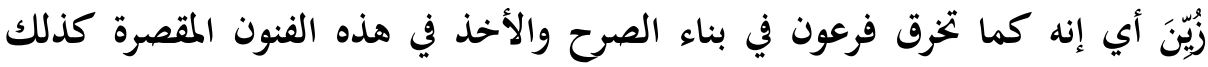

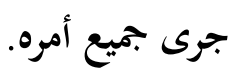

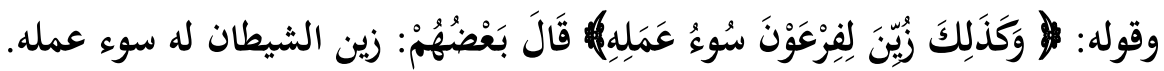

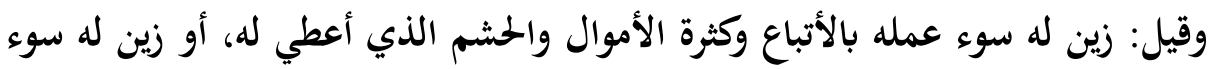

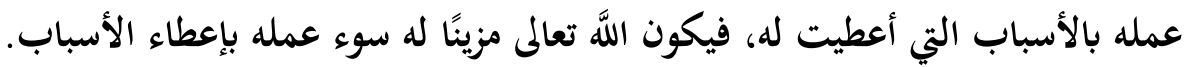
وقيل: زين له سوء عمله، أي: خلق في طبعه أن يرى ذلك حسنا مزينًا وإن كان قبيحًا في نفسه حقيقة . وقيل: الذي زين لفرعون سوء عمله جهله، فلما جهل أن له ربا يجب عليه عبادته وتوهم

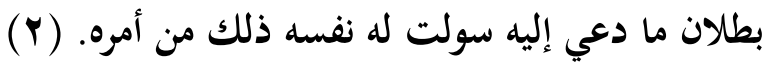

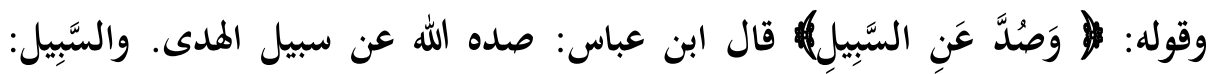

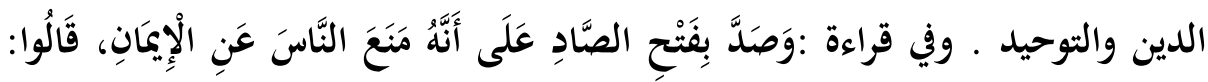

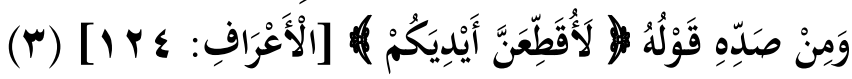

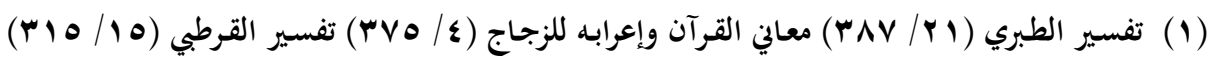

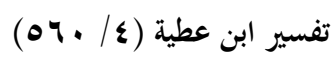

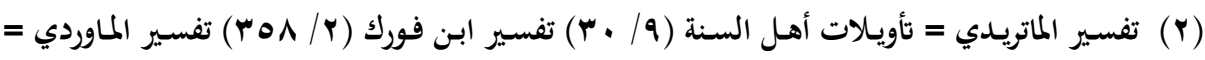

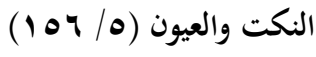

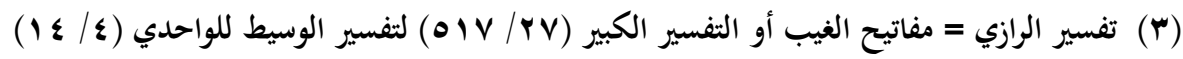




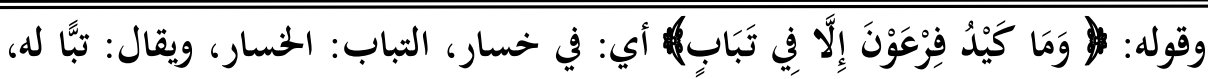

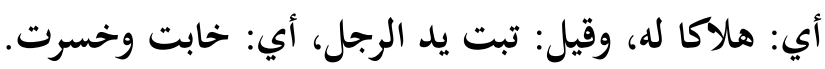

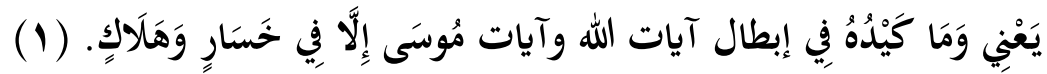

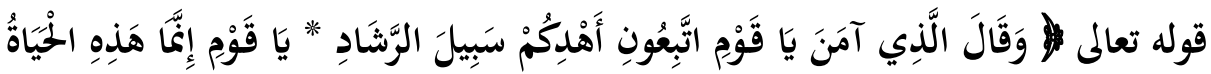

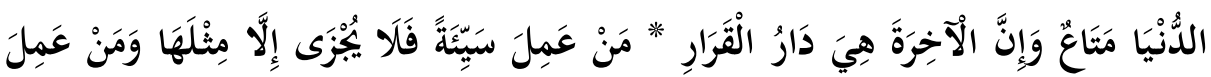

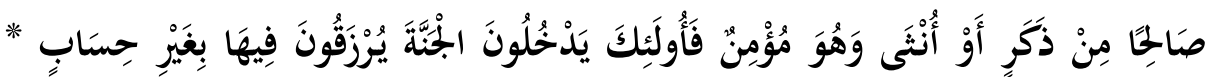

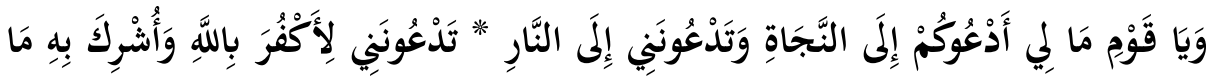

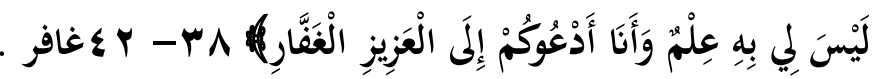

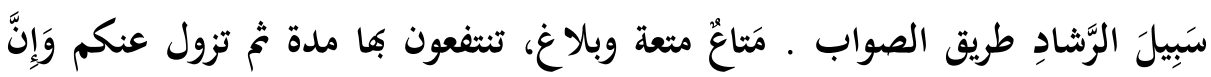

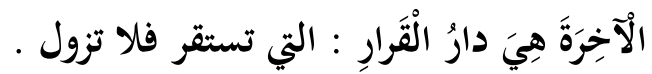
وفي هذا تصريح واضح بإيمانه وبيان مفردات إيمانه بالله والحساب واليوم الآخر. وأنه على علم بأسماء الله تعالى (ץ)

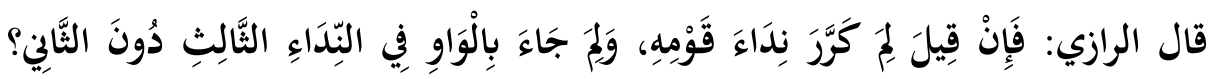

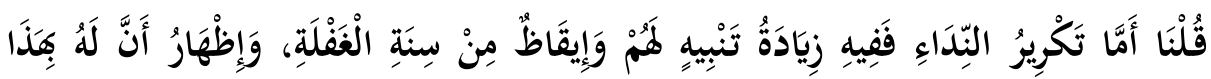

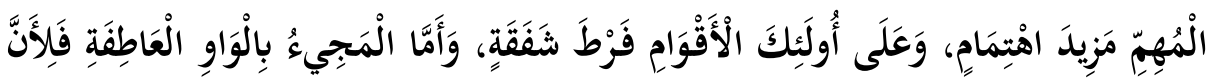

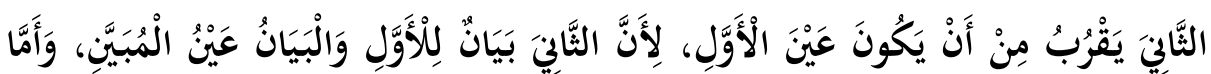

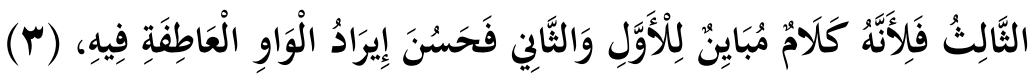

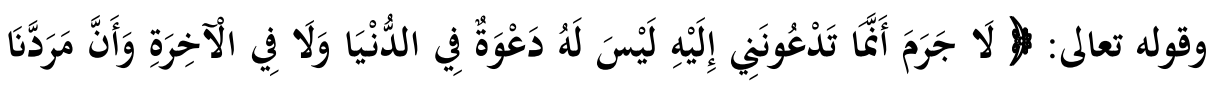

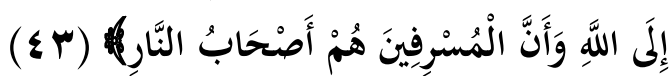

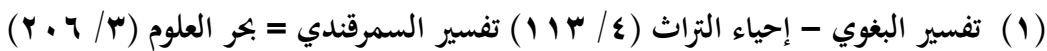

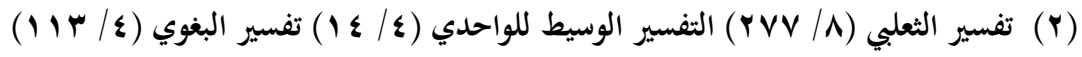

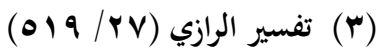


لا جرم (لا) زائدة، وجرم : حق. اي: حقا أن الذي تدعونني إليه من الأوثان ليس له

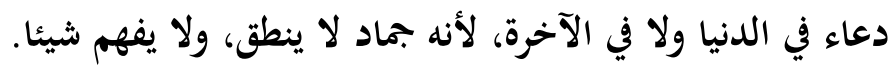

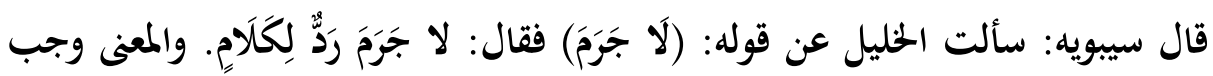

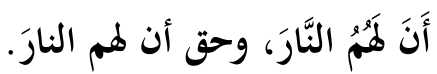

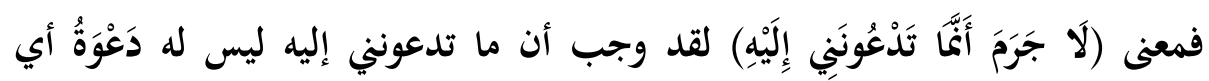

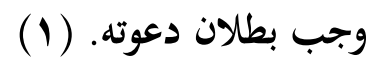

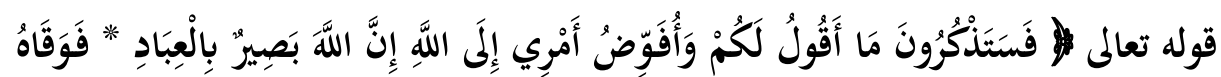

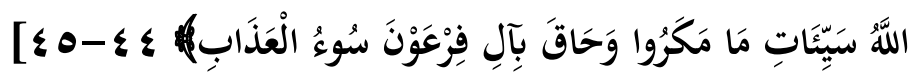

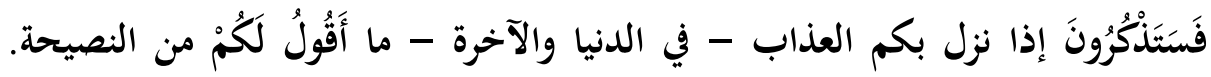

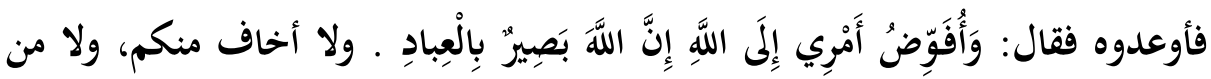
كيدكم.

قيل: هرب المؤمن إلى الجبل فطلبه رجلان فلم يقدرا عليه. لكن المقصود نجاته مع موسى

لأنه ذكر في المقابل أته حاق بآل فرعون سوء العذاب وهو الغوريل

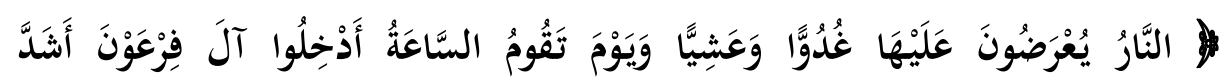

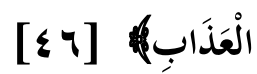
النَّارُ يُعْرَضُونَ عَلَيْها في قبورهم المفترضة، وكذلك إن كانت معلومة، وذلك أن أرواح آل

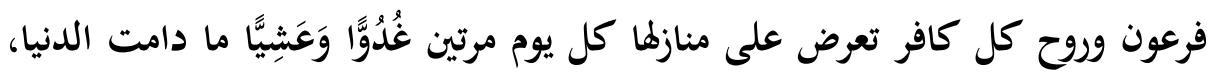

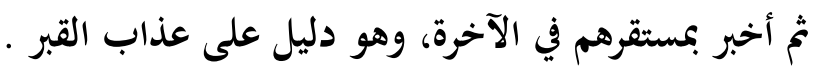

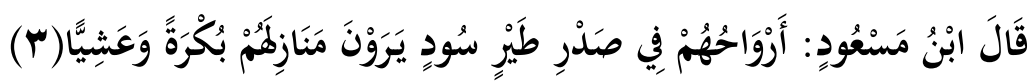

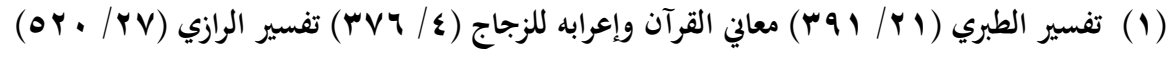

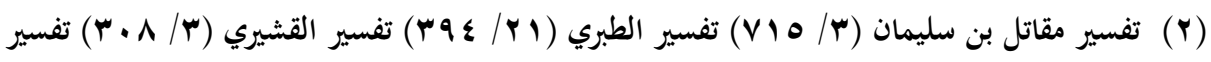

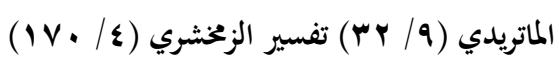

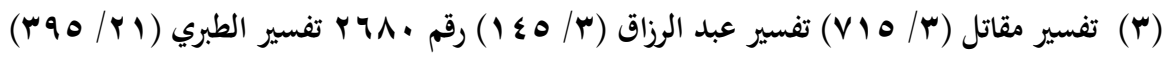


Ү

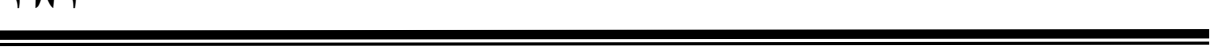




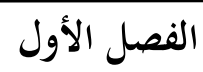

الحوار التربوي

وفيه مباحث

المبحث الأول: التربية في الخطاب

المبحث الثاني: التربية في كيفية بناء الدولة

المبحث الثالث: التربية في تعليم أسس الجهاد الذي تقوم عليه الدولة 
Y^

 


$$
\text { التربية في الحطاب الأول }
$$

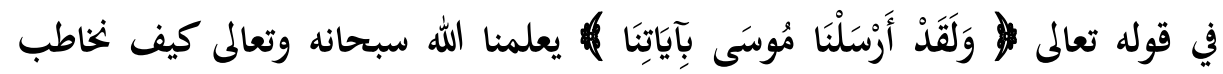
الناس وأي أسلوب نسلك معهم لإيصال ما نريد ، فأمرنا بحسن الأسلوب، والاعتماد الإنا

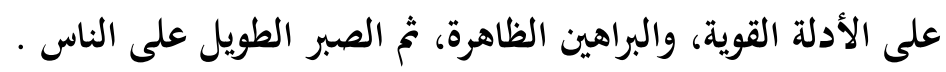

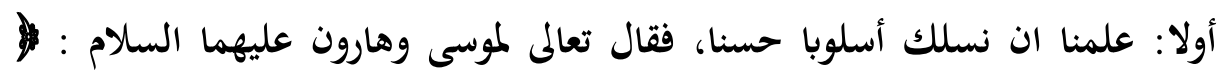

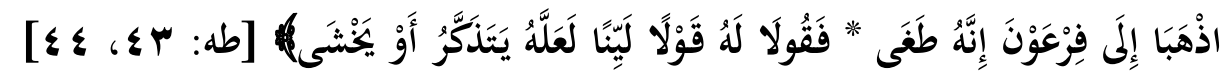

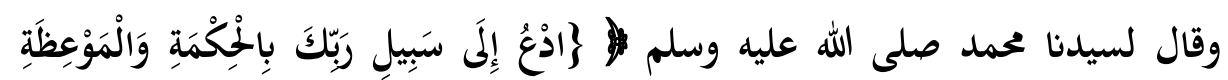

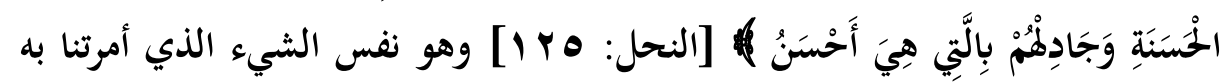

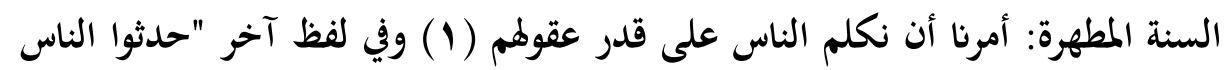

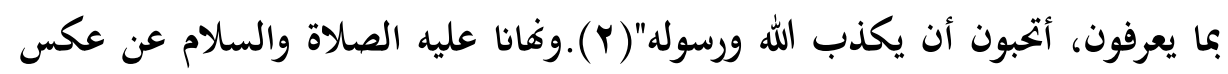

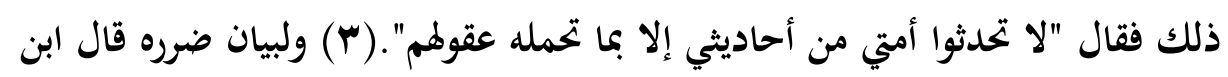

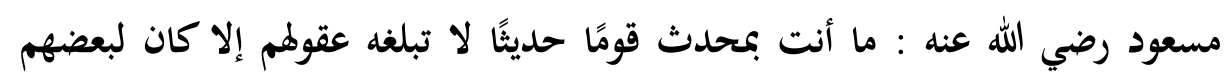

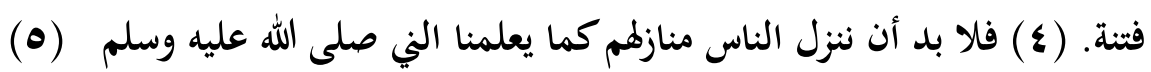

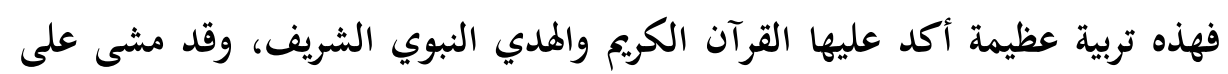

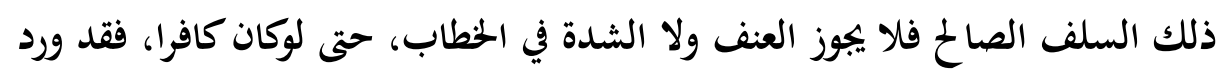

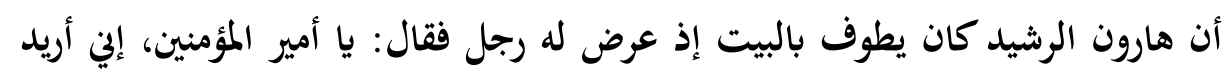

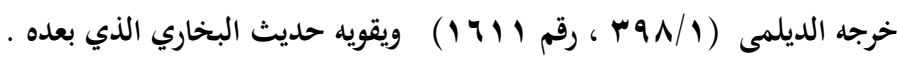

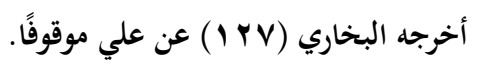

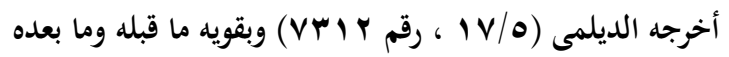

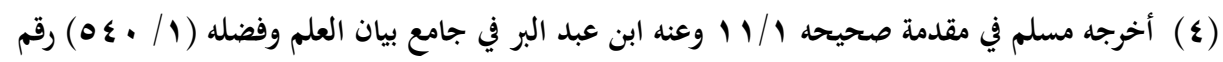

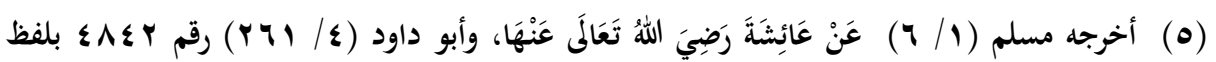

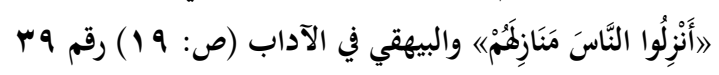


أن أكلمك بكلام فيه غلظة فاحتمله لي، فقال: لا، ولا نعمة عين ولا كرامة، قد بعث

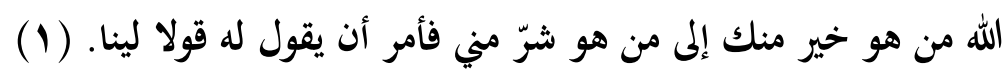

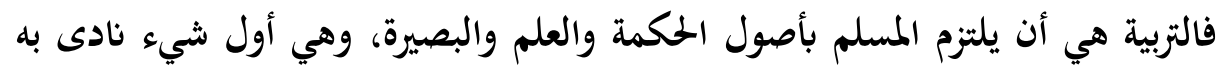

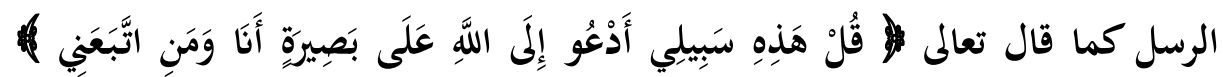

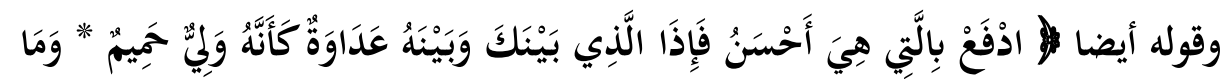

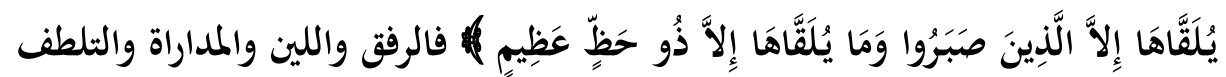
بالكلام واجب تربوي (Y) كما بينت هذه الآيات، وبذلك يلك يعلمنا النبي صلى الله عليه وسلم فيقول عندما أرسل أبا موسى الأشعري ومعاذا رضي الله عنهما إلى اليمن " ادعُوَا

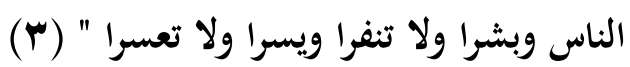
وبطريقة عملية نذكر بمواقف تربوية فعلها رسول الله صلى الله عليه وسلم في الطائف ولف ولفراس

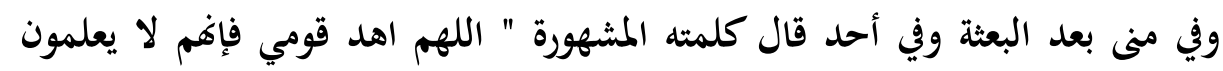

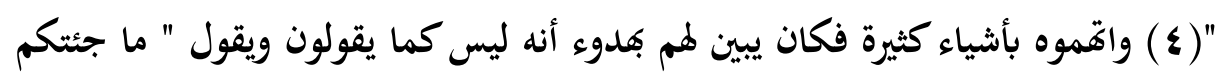
بما جئتكم به أطلب أموالكم ولا الشرف فيكم ولا الملك عليكم، ولكن الله بعثني إليكم

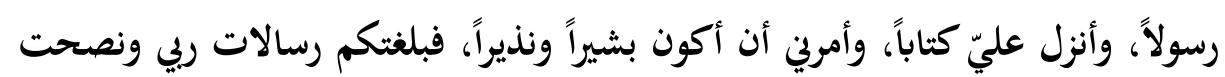

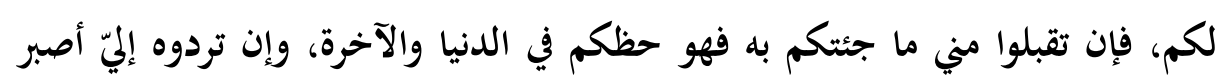

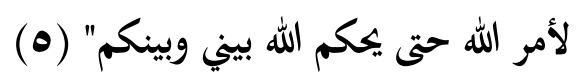

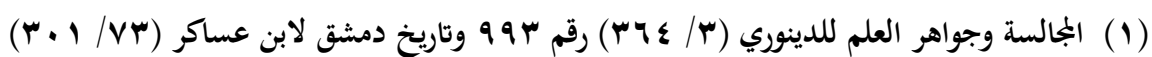

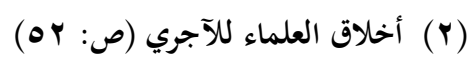

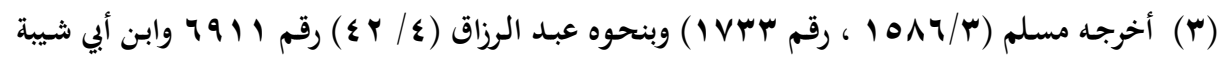

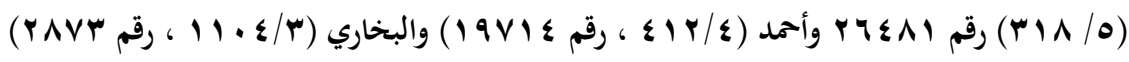

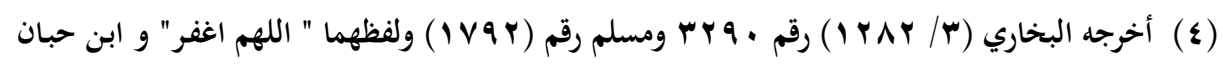

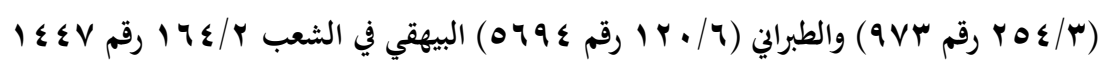

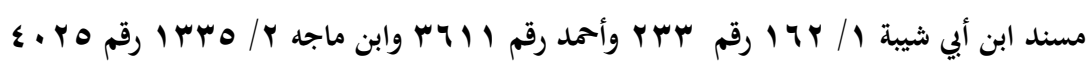

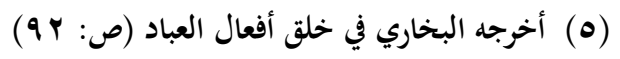


وقد تسرعت عائشة رضي الله عنها ذات مرة فقال لما رسول الله صلى الله عليه وسلم

"عليك بالرفق فإن الرفق لا يكون في شيء إلا زانه ولا ينزع من شيء إلا شانه"(

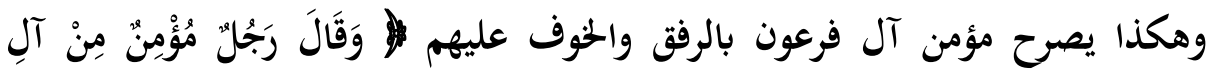

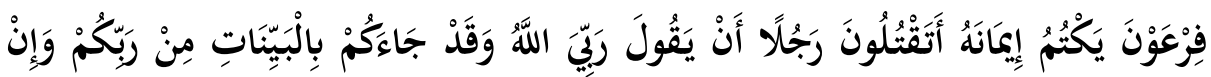

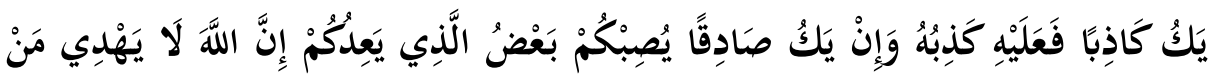

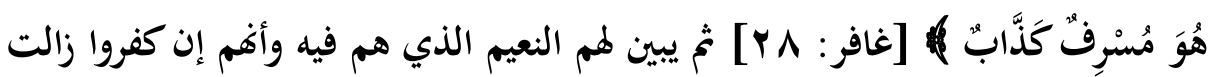

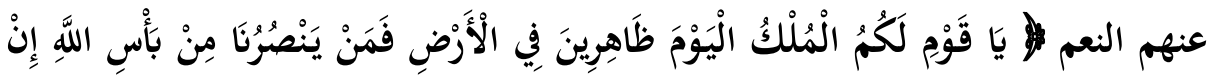

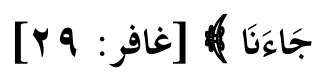
ثانيا: وعلمنا أن نقدم الأدلة القوية والحجج الدامغة، التي اعتمد عليها الأنبياء الذين

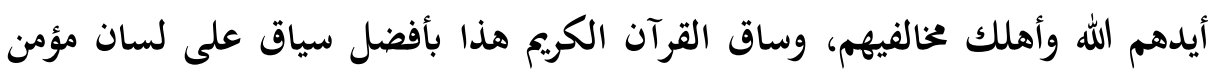

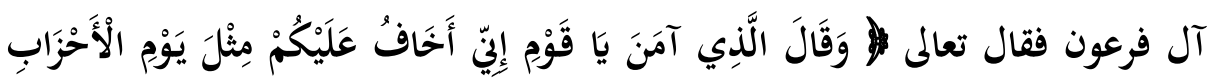

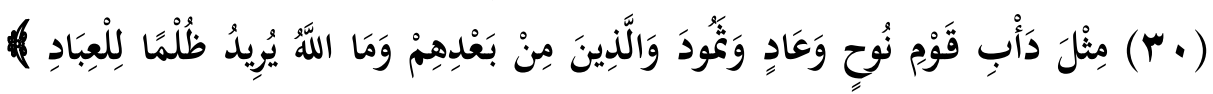

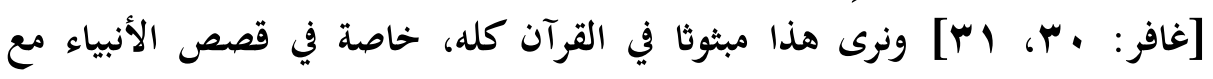
أقوامهم.

ثالثا: البراهين القاطعة، وذلك من خلال قوله تعالمى وَسُلْطَانِ مُبِينٍ مُ أي بالأدلة التي لها سلطان على العقول كالمعجزات تدل على صدق نبوة البي، وهي أدلة لا يملكها

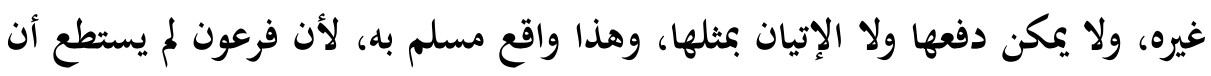
يأتي بمثلها ولما أوهم نفسه بذلك انزم أمام معجزة العصا فقط، ولم يكن أمامه إلا ئل التهديد باستعمال القوة، واهزمت قوته أمام المعجزات الأخرى، حتى اضطر هو لهدم وأركان دولته إلى تعطف موسى أن يرفع عنهم البلاء ، وتكرر هذا تسع مرات، ومن خلال ذلك

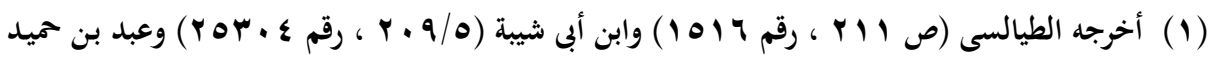

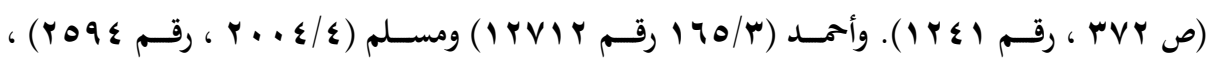

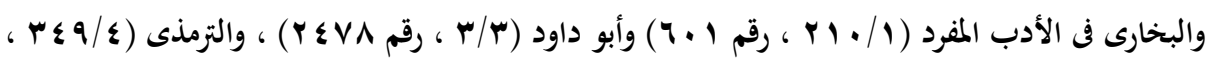

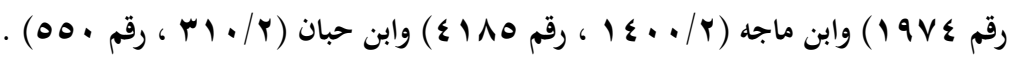


كان عنده علم يقيني بأن رب موسى هو الذي يرفع البلاء ، وظل على عناده ومراوغته، رغم عجزه الكامل عن دفع آية واحدة . فقد راوغ تارة بالسحرة ففشلت هذه المراوغة فشلا عزيا أمام الناس في مملكته كلها

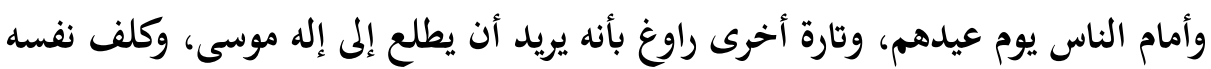
ببناء صرح عال عظيم ليرى أسباب السموات، ولم يقدم تفسيراً لأحد أنه فعل شيئا ، إلا لأل

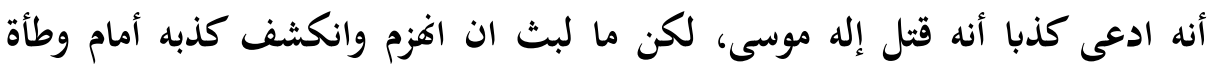

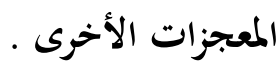
رابعا: الصبر ـ ومن خلال ما تقدم يبرز معنا أمر هام آخر من الأمور التربوية وهو الصبر

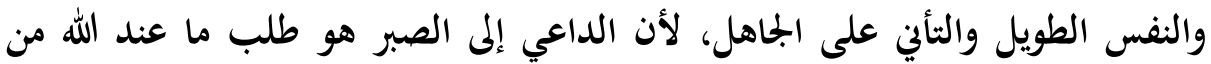

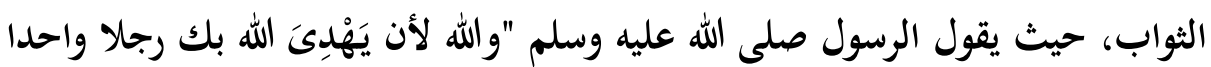

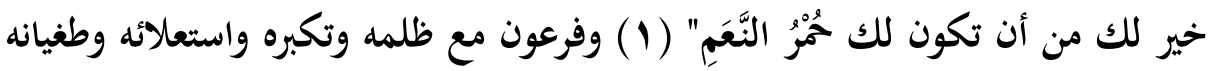
وامتناعه قبول الحق كل ذلك بإفراط شديد صبر عليه موسى عليه السلام سنينا طويلة

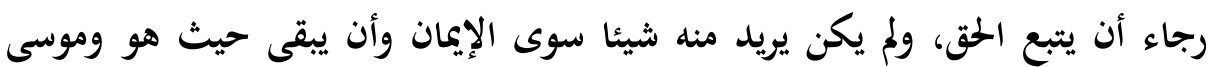

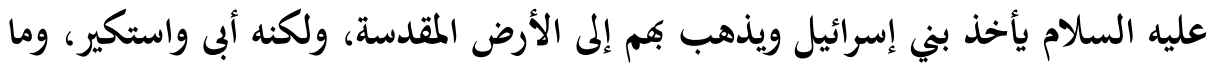

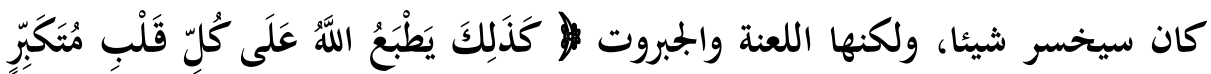

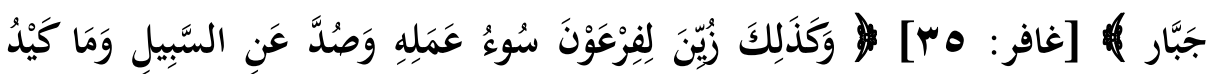

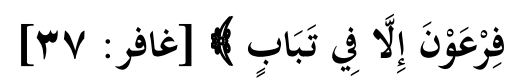

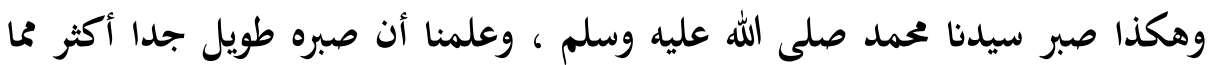
يتصور الكفرة أنفسهم، وأعلنها قائلا " بل أرجو أن يخرج الله من أصلابكم من يعبد الله

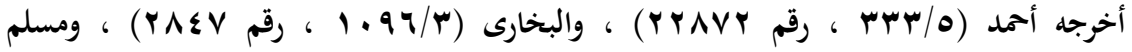


YAN

وحده لا يشرك به شيئا " (1) وكان يفرح فرحا شديدا إذا دخل أحد منهم في الإسلام

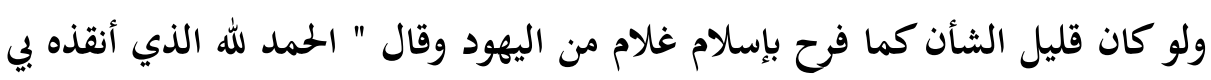

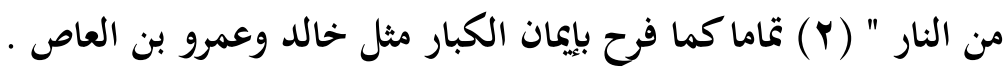
فأي تربية هذه التي تطلب من العالم أن يتحلى بالصبر على عدوه ليس سنينا وإنما أجيالا وهو يدعو لمم بالمداية .

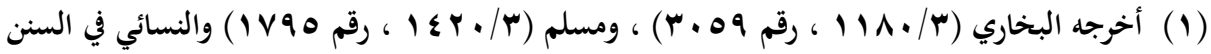

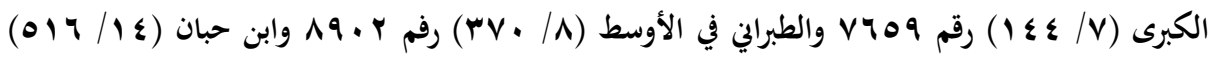
رقم

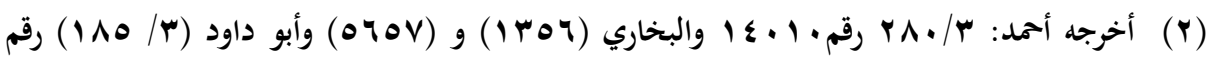

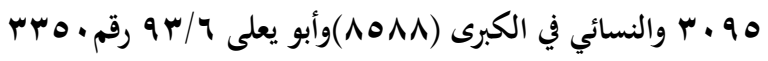


المبحث الثاني

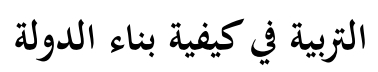

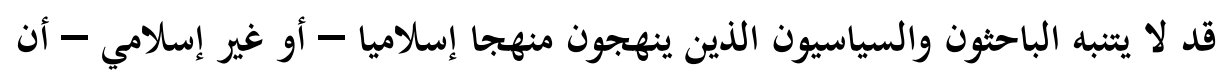

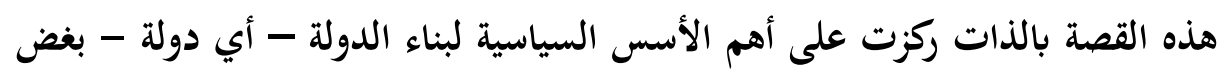

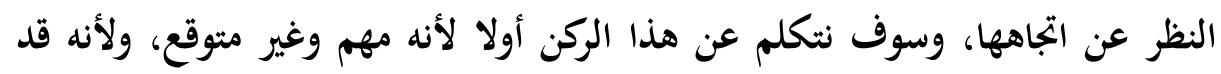

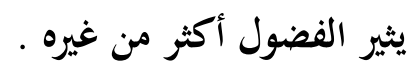
وهذا الركن المهم هو اتخاذ العيون في عقر دار العدو ، ونقصد بالعيون هنا الجواسيس في

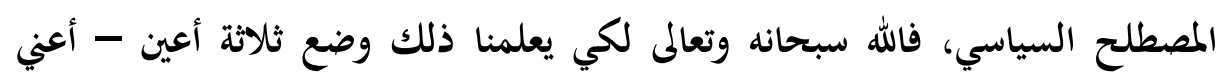

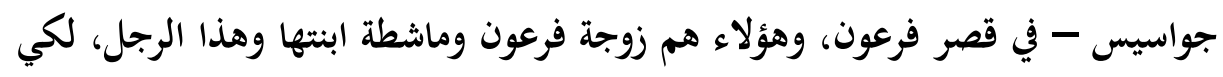
يستفيد منهم موسى في الأخبار وصناعة القرار .

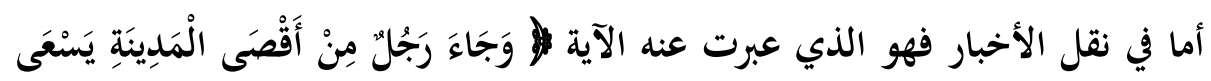

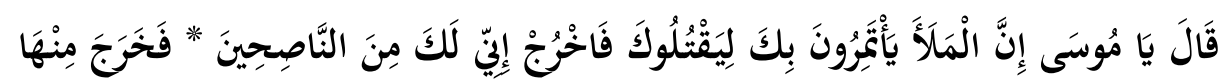

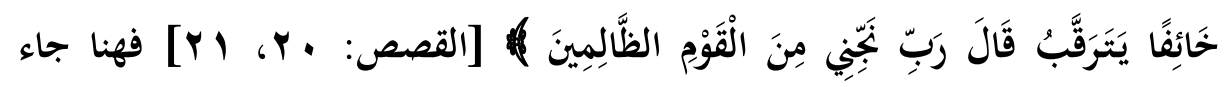

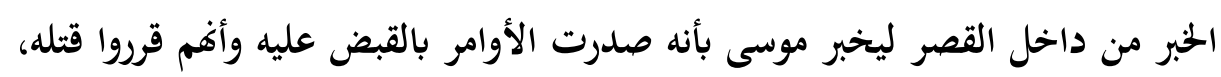

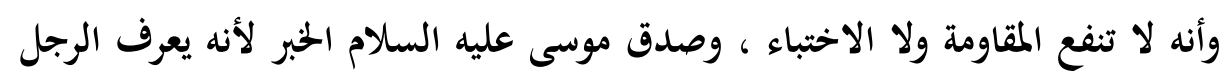

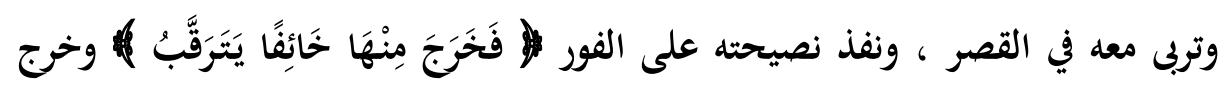

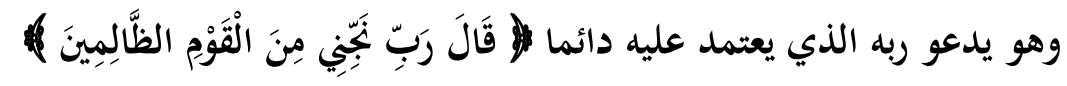

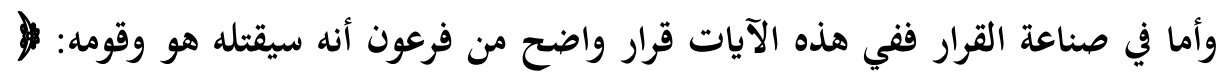

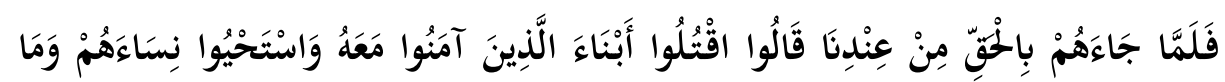

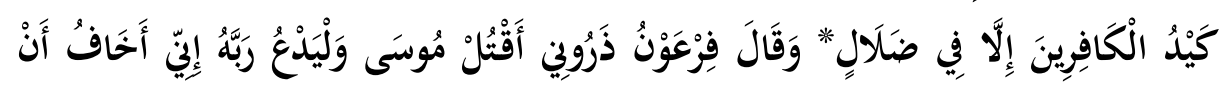

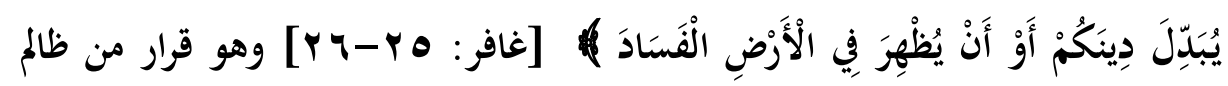

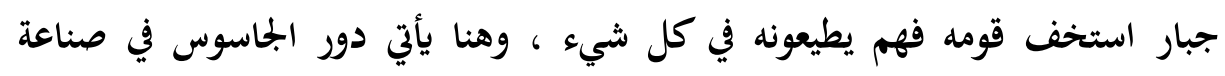

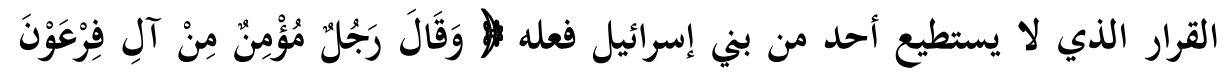

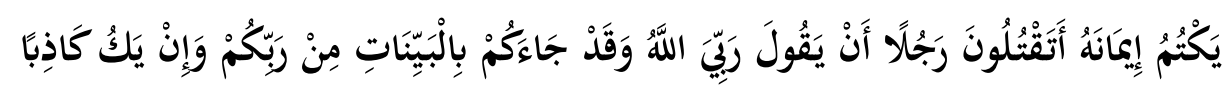




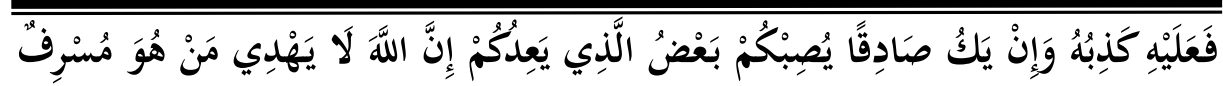

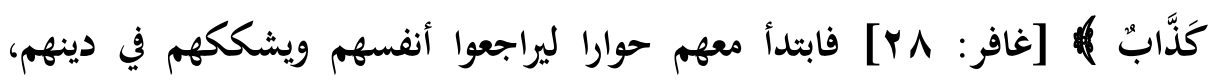
ويصرف نظرهم عن القضية الأساسية وهي قتل موسى وقومه، ونجح في ذلك نجاحا عظيما، فانصرف فرعون لكي يبني صرحا عظيما عاليا لكي يطلع إلى إله موسى، وأخذا

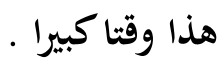

إذن قضية اتخاذ الجواسيس أمر مهم في الحرب مع العدو ، لأن المعركة لا تبدأ بإرسال

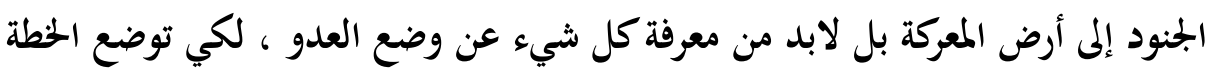

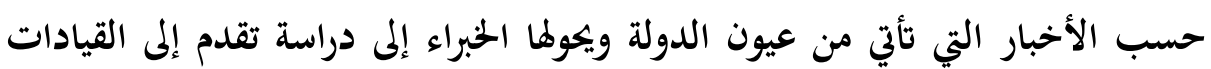

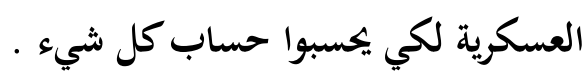

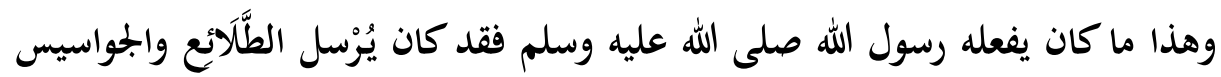

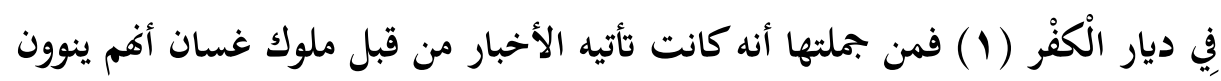

$$
\text { محاربته وينعلون الحيل استعدادا للحرب (Y) }
$$

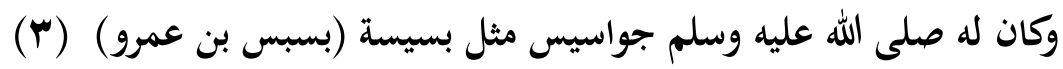

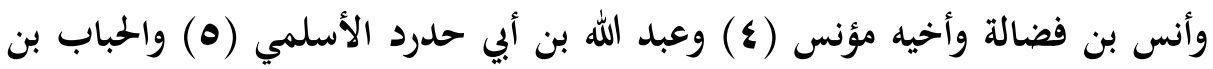

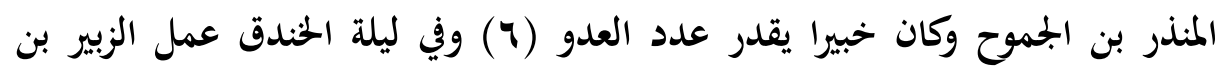

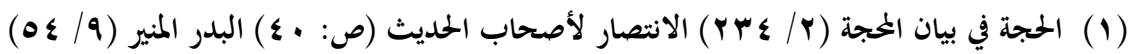

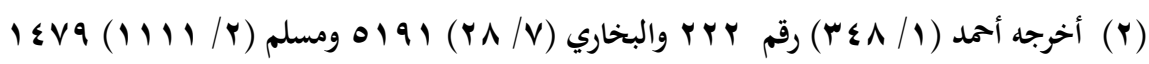

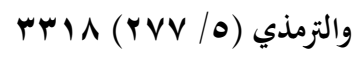

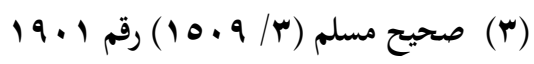

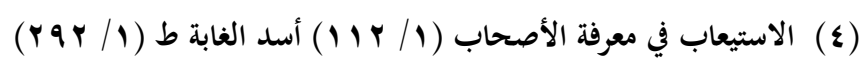

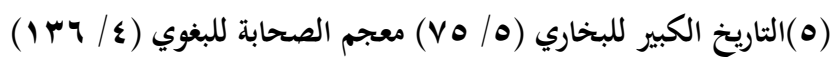

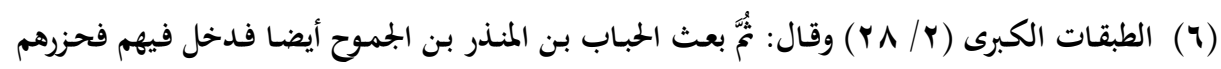


العوام جاسوسا عسكريا فدخل في صفوف المثركين وعرف خبرهم بأمر البي صلى الله عليه وسلم كما في الحديث الصحيح المشهور (1) وقد ساق الله يوم الحندق أيضا نعيم بن مسعود الأشجعي حيث أسلم أثناء الحرب، فقال له النبي صلى الله عليه وسلم "خذل عنا ما استطعت" فقال: إيذن لي فقال " قل ما بدا لك فإن الحرب خدعة" (Y) وكان رسول الله ترك عمه العباس في مكة ولم يجيره

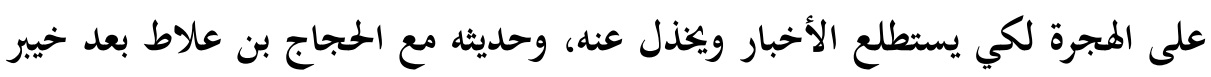
يدل على ذلك. (ب) وكانت لعمر، رحمه الله ورضي عنه، في كل جيش عيون يتعرفون الأخبار من قبلهم،

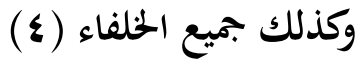
وهكذا كان حكام المسلمين لمم جهاز كبير جدا يُدرّب أفراده على الدخول في صفوف الأعداء وفي قصورهم ليتعرفوا على أدق التفاصيل عن عدوهم .

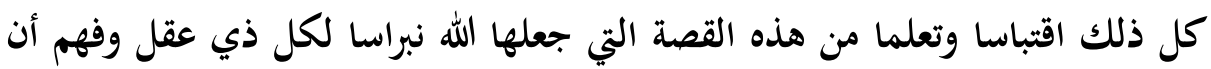
لا يأمن لعدوه ولا يغفل عنه .

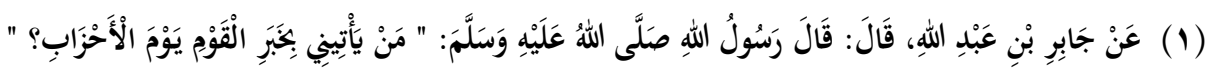

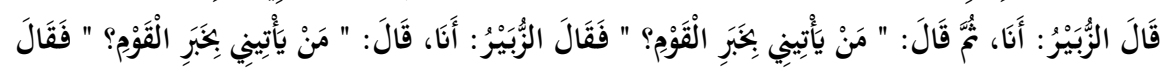

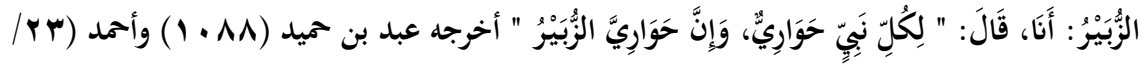

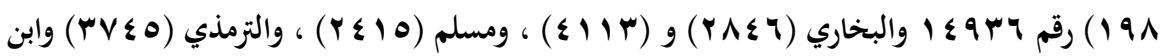

$$
\text { ماجه (r) }
$$

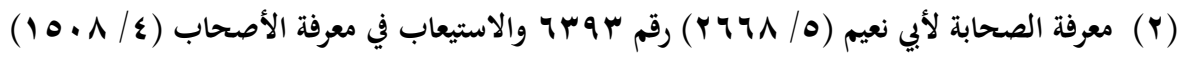

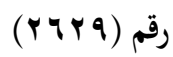

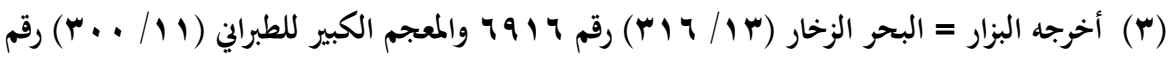


ومن قبله قصة يوسف عليه السلام كذلك، حيث اقتلعه الله من حضن أبيه الخليل ليرمي به في الجب ولكن ليزرعه الله في قصر الملك لكي يغير معالم الدنيا، وينورها بأنوار

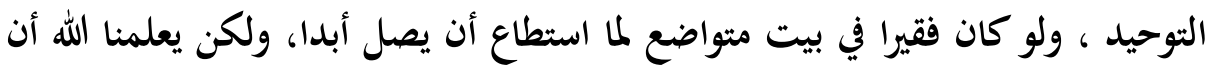

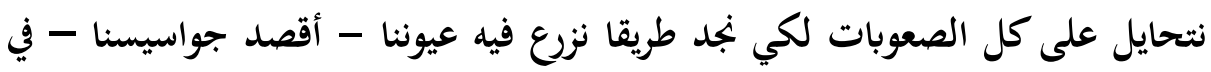
قصور أعدائنا .

وهكذا تعلم الناس على لسان الأنبياء هذه الأمور الأساسية لبناء الدولة القوية التي لا

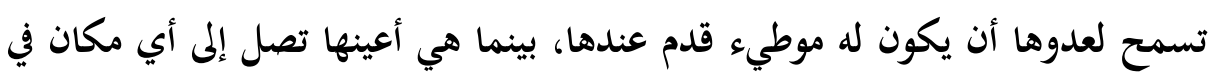
قصور ملوكها .

ولكننا غفلنا اليوم عن هذا الركن حتى وقعنا في عكس ذلك، وأصبحت أخبارنا عند عدونا فاحتل ديارنا قرونا طويلة، ولم يخرج حتى جعل جدران الأزقة جواسيس له . . ولقد نسينا أن حروبنا مع الصليبيين والمغول كانت حرب جواسيس، فكلما تفوقوا علينا في هذا الميدان غلبونا، فإن انتبهنا وعرفنا مداخلهم ومخارجهم غلبناهم وطردناهم، ومن

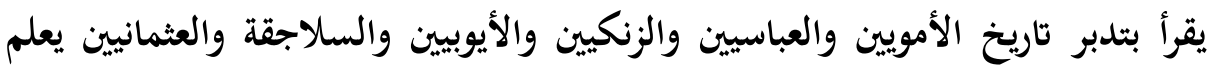
عِلم اليقين أن حروب الكر والفر تابعة للتفوق في هذه الحرب.

خاصة آخر ملوك بني عثمان الذي قتل ثلاثة وصلوا المى درجة رئيس وزراء (1) إن قصة مؤمن آل فرعون لم يقصها الله علينا عبثا ولكن لكي نكون عالمين بالأركان التي

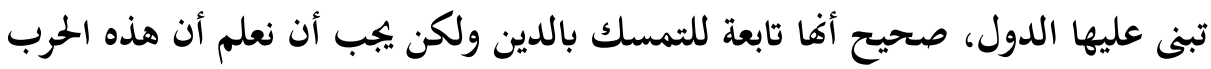
من الدين بل ومن صميم القرآن وهديه :

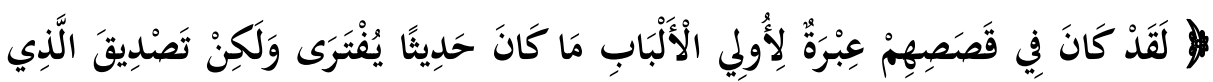

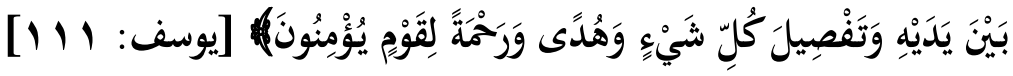




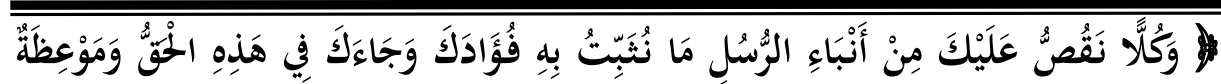

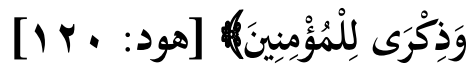

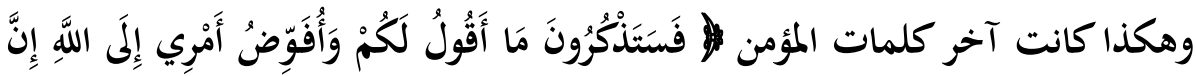

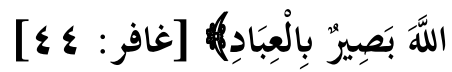

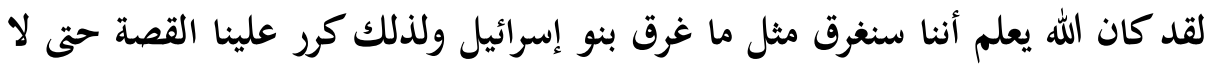

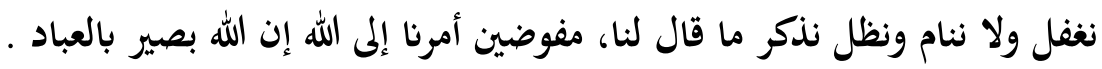




\section{المبحث الثالث}

التربية في تعليم أسس الجهاد الذي تقوم عليه الدولة

يتبادر إلى الذهن أن هذا مبحث خاص للجهاد والقتال والسلاح والحرب، ولكن ليس في القصة شيء من هذا وإنما هو جهاد الكلمة، إنما كلمة ولكن ليست من باب الدعوة ولكن من باب الجهاد ، جهاد المستميت وجهاد العالم وجهاد الثابت على المبدأ . لقد كان مؤمن آل فرعون ليس ججرد داعية ولكنه ججاهد قد وطن نفسه على الموت، ومقاتل مغوار من الطراز الأول ألقى بنفسه في غمار العدو في قلب المعركة، وكان معه سلاحان سالاح الإيمان بالله وسلاح الكلمة . أما سلاح الإيمان فهو أساس لبناء أي دولة، وهذا شيء معروف وشرحه يطول، ولا يكتمله البحث .

وأما سلاح الكلمة فهو جهاد العلماء ، وإذا كانت في مواجهة المتسلطين الجبابرة فهي أعلى مراتب الجهاد ، والثهيد فيها سيد الثهداء ، كما قال الرسول صلى الله عليه

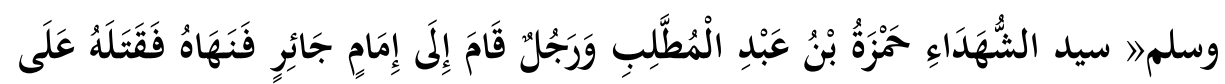

ذَلكَكَ

وقد سمى النبي صلى الله عليه وسلم مؤمن آل فرعون بالصديق كما تقدم (Y) أي أعطاه درجة أعلى، وهنا لا بد من وقفة، فتسميته صديقا لها قيمة تربوية عظيمة جدا، قد لا يتنبه لها الكثيرون، وهي إضفاء رتبة الصديقية على من يصدع بالحق أمام الجبابرة، ويكون عالما بما يقول، فمجرد القول يدخله في رتبة الصديقية فإن قتل فهو صديق

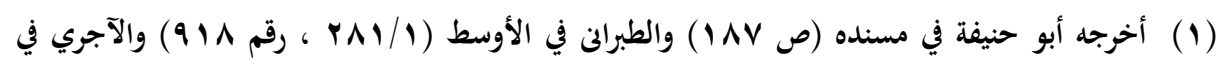

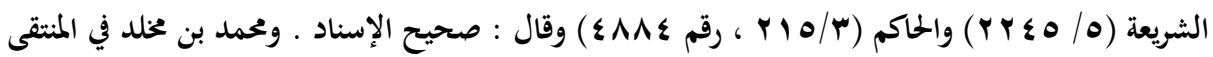

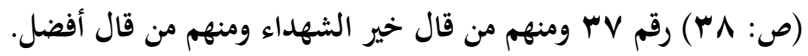

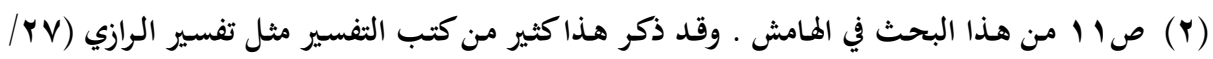

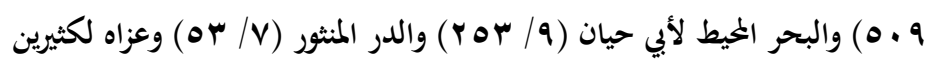


وشهيد سيد، بمقتضى نص الحديثين، وما دام أنه عالم فهو يعلم عظم المرتبة التي يتقدم إليها، فهي تربية للنفوس العظيمة التي لا تخاف في قول الحق لومة لائم.

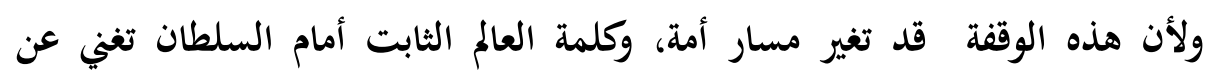
الآلاف المؤلفة من الجيوش وتدبير الانقلابات التي قد تزهق فيها أرواح أبرياء كثيرين ،

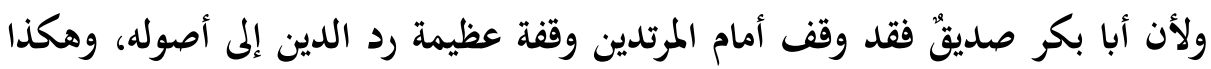
فعل السلف الصالح في المواقف العظيمة، ومن ينسى ما فعله الإمام أحمد بن حنبل في

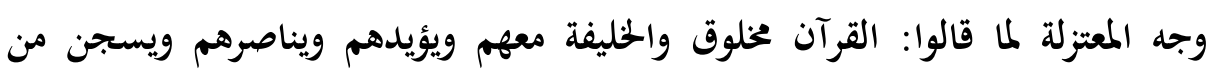
يخالفهم، ووقف الإمام احمد العالم الجليل يناقشهم في حضرة الخليفة، ويبين خطأهم ولولاه لصارت الأمة كلها معتزلة، ذات عقيدة فاسدة، ولو أن الإمام احمد رحمه الله

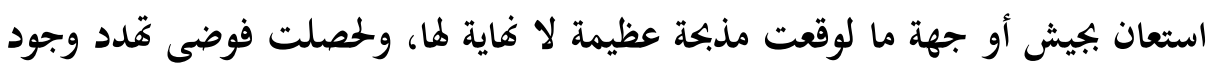

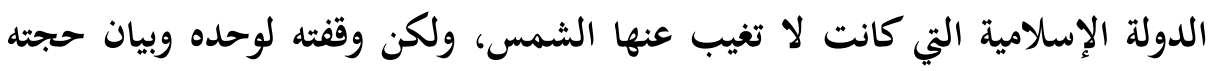
وقوتما أغنت عن جيوش الأرض، وثبت على مبدئه واعتقاده، ولم يبال بالسجن والتعذيب طيلة ثمانية عشر عاما ـ (1)

(1) وقد وصف الإمام أحمد بالصديقية الخليفة العباسي المتوكل كما نقل عبد الغني المقدسي في كتابه المحنة

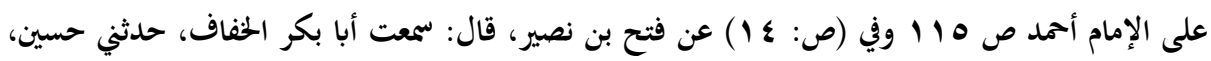

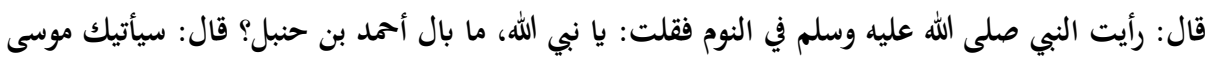

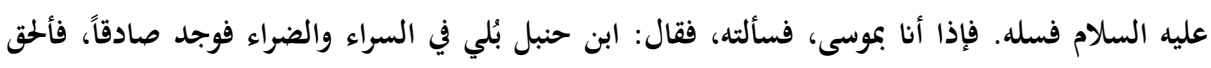
بالصديقين، وقال في (ص: 10 ) حدثنا أبو العباس الصوفي، قال: كنا يوماً في المسجد الجامع ننتظر السري رحمه الله، وكان في المسجد خلف وأبو بكر الناقد صاحب الحببي وابن أخي معروف الكرخي، فقال أبو يوسف ابن أخي

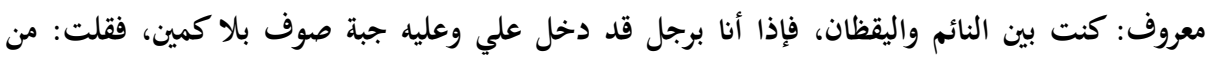

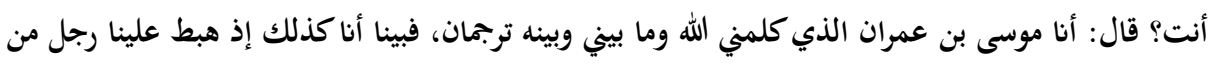
السقف عليه حلتان، جعد الشعر، فقلت: من هذا؟ فقال لي: هذا عيسى ابن مريم عليه السلام، ثم قال لمي لي

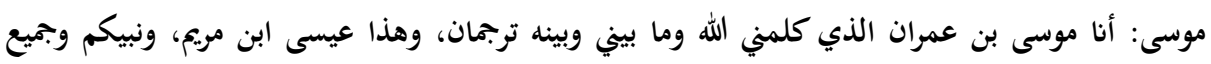

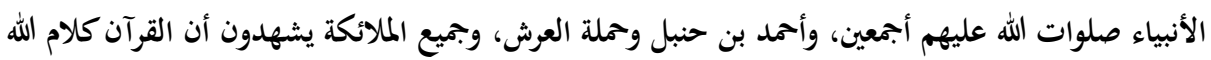


ولذا قال هلال بن العلاء الرقي: منَّ الله على هذه الأمة بأربعة في زمافم: بأحمد بن

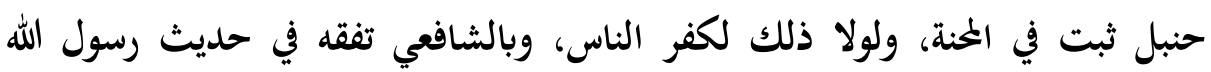
صلى الله عليه وسلم • وييى بن معين نفى الكذب عن رسول الله صلى الله عليه وسلم .

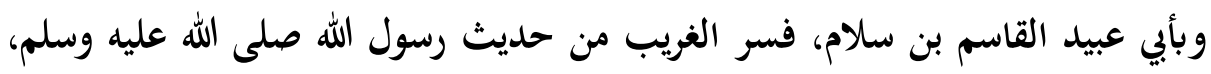

ولولا ذلك لاقتحم الناس في الخطأ. (1) إذن موقف العالم الثابت في المكان الصحيح هو بمثابة أمة كالرسل تماما، ولذا قال تعالم

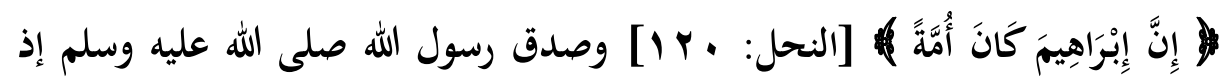

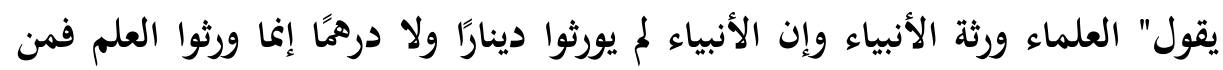
أخذه أخذ بحظ وافر " (r) هذه هي التربية الإسلامية الحقيقية التي ظهرت من خلال قصة مؤمن آل فرعون .

غير مخلوق، فقال خلف: قد قلت لأبي عبد الله هذه المقالة، فقال: أشتهي أن أسععها من فيه. قال له ابن أخي معروف: غداً أركب حماراً وأمضي إليه. قال أبو العباس: أنا أقول: الناس من دورا إله أحمد كلهم في ميزان أحمد، كما أن الناس دون أبي بكر في ميزان أبي بكر.

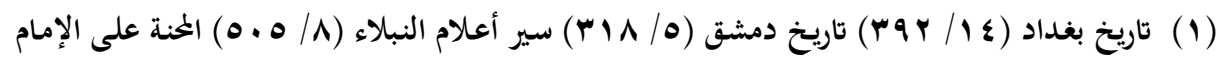

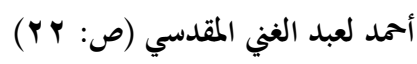

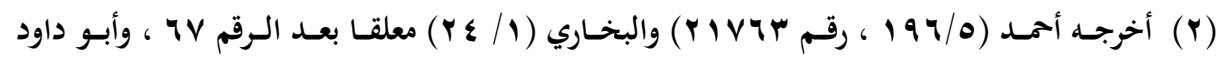

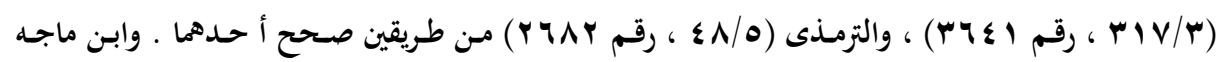

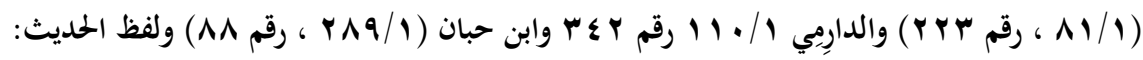

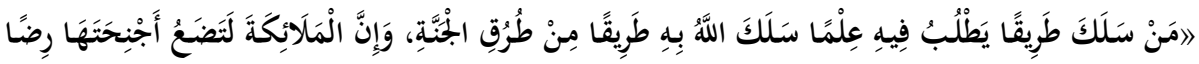

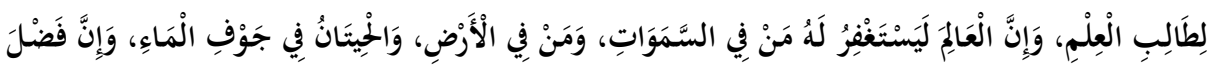

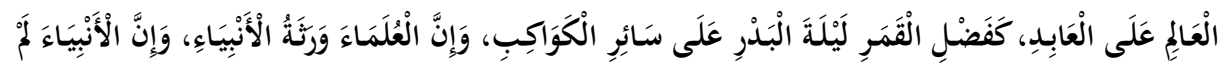

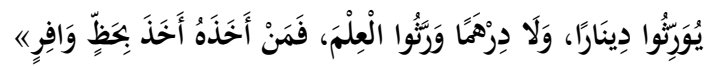


والملفت للنظر أيضا - والقصة كلها ملفتة للنظر - أن الله تعلى يعلق على القصة

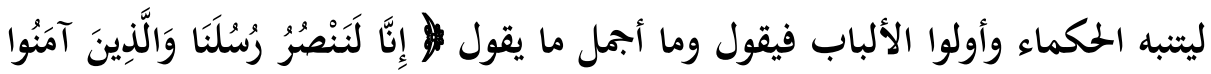

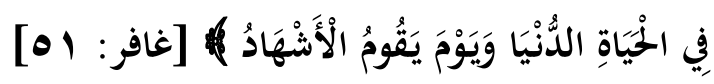
فحقق الله وعده لمؤمن آل فرعون:

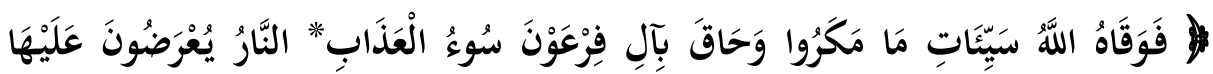

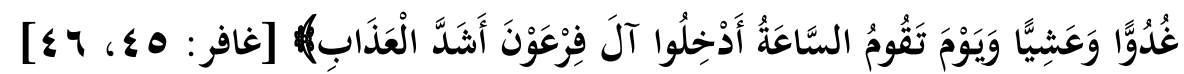

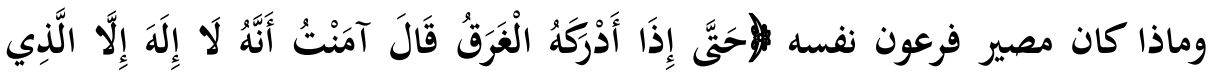

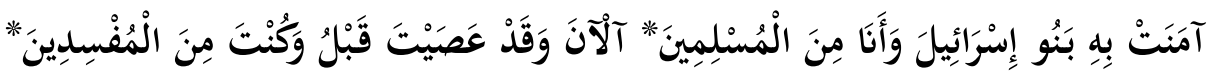

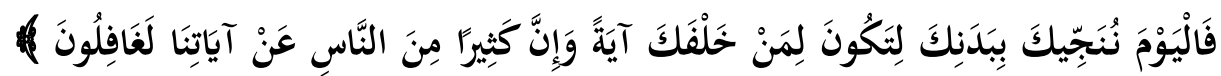

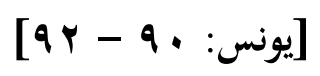

وماذا حصل لهم في الدنيا؟ لقد دعا عليهم رسول الله موسى عليه السلام:

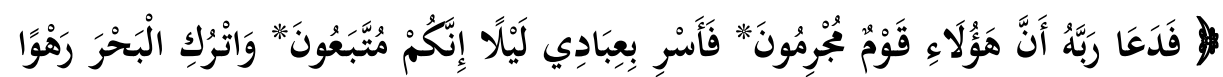

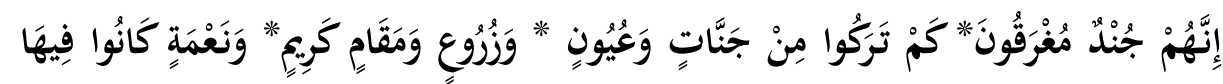

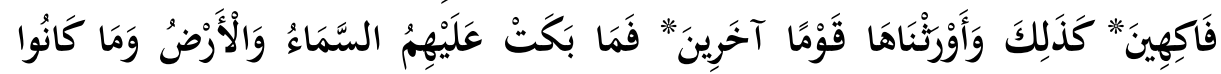

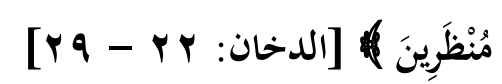

يا إلهي ! ما أقسى هذه الكلمة على الكافر لوكان عنده ذرة عقل أو لحمة تدبر.

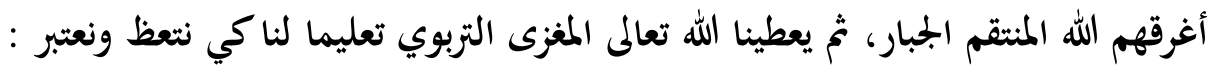
أغم ما بكت عليهم السماء والأرض، لم يتأسف على هلاكهم أحد ، لأن الظالم يتمنى زواله كل مظلوم فلا يأسف عليه مخلوق، ويلعنه كل شيء وتلعنه السموات والأرض:

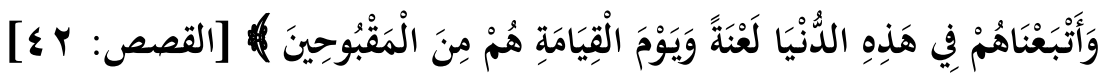

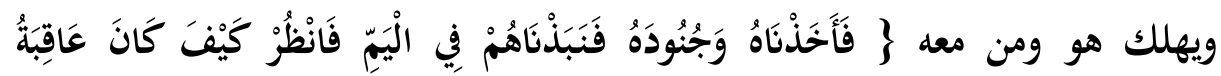
الظَّلمِينَ) [القصص: · عـ وهذا سر قوله صلى الله عليه وسلم " إن الله ليملى للظالم 
حتى إذا أخذه لم يفلته" (1) لأن الله لو أهلكه من البداية لقيل لا يستحق ولكن يملي له حتى تكرهd ثيابه .

إذن فالله سبحانه تكفل بالنصر وما دام أن الله هو الذي يرسل رسله والذين آمنوا أيضا فلا بد أن ينصرهم، ولو اقتضى الأمر أن يفني العالم من أجلهم لأفناهم ولا يبالي، وها

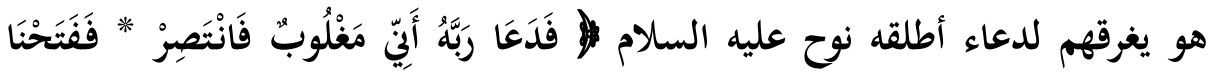

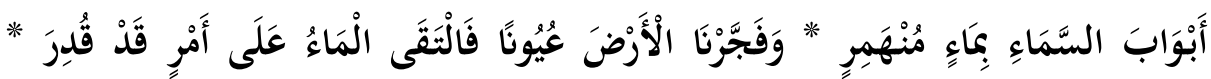

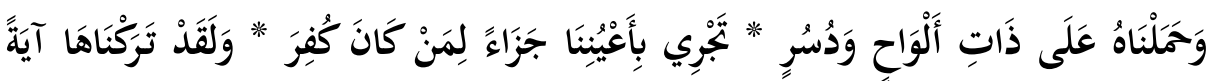

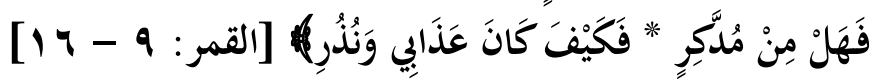
وها هم قوم عاد العماليق الذين أعطاهم قوة لم يعطها لأحد وسكنوا أحسن البلاد التي

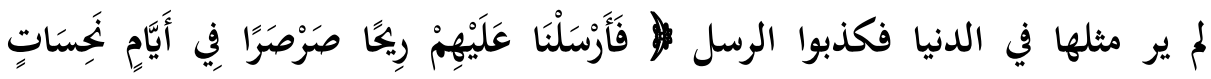

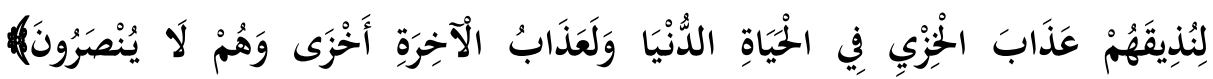

$$
\text { [ فصلت: } 7 \text { [ } 17
$$

وأي ريح هذه؟ ماذا فعلت بأحسن دولة في التاريخ؟ :

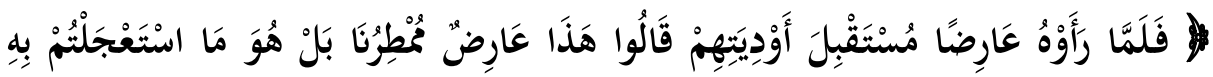

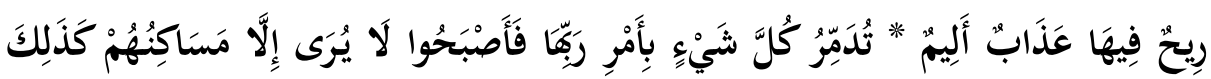

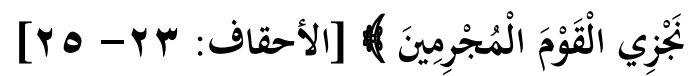
وما هي قوة هذه الريح؟:

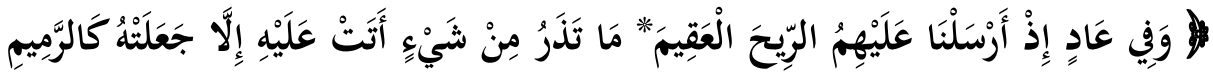

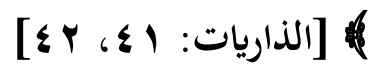

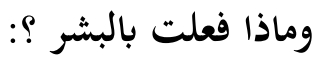

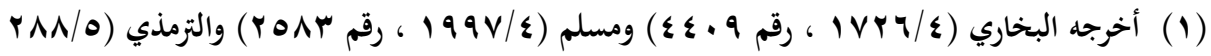

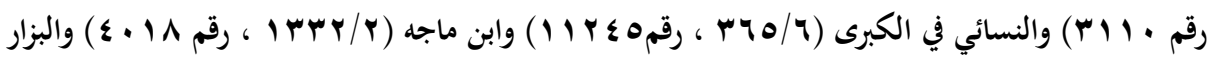

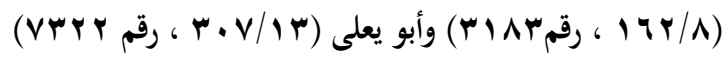




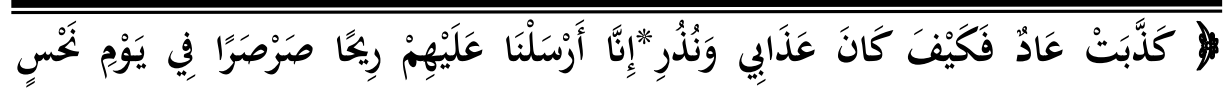

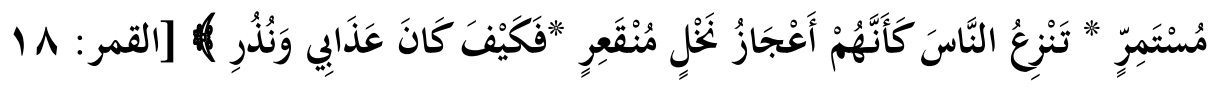
$[r]-$ وبعد كل هذا يوجه الله سبحانه الخطاب لنا نحن، وهنا يأتي دور التربية، بعد عرض القصة

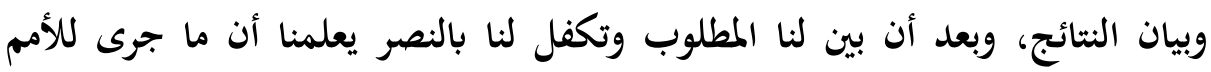

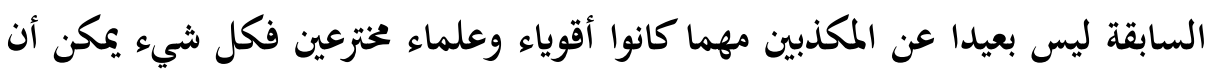

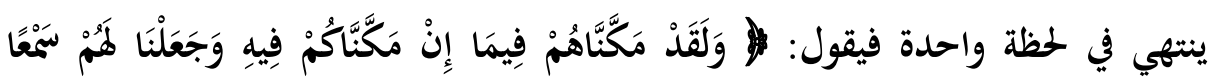

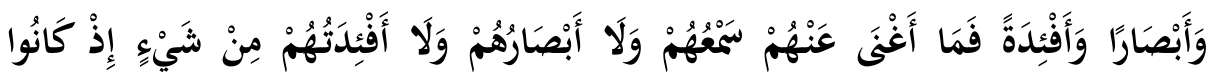

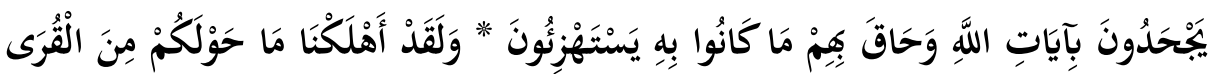

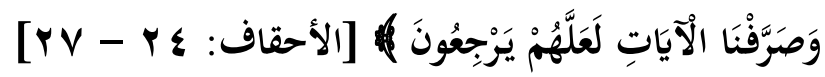
تثبيت ما بعده تثبيت وتربية ما بعدها تربية وحقيقة ما بعدها حقيقة، لو أن دولة عظمى

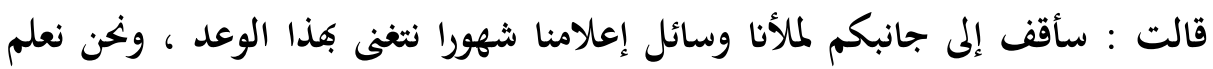
أغم كاذبون، وهذا وعد الله القادر الغالب الذي لا يغلبه شيء ولا يعجزه شيء، يعدنا بوعده الصادق ويهدد عدوّنا بقوته الغالبة وقدرته على التنفيذ . ونخن اليوم لو وقفنا وراء علمائنا لتغير حالنا، بل لم نصل إلى ما وصلنا إليه، لأن الأمة

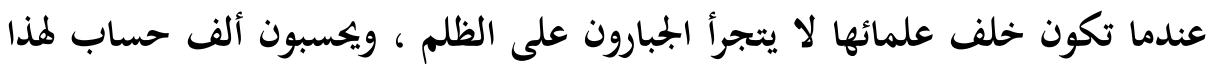
الجمهور . وهذا ما فعله الخليفة العباسي المتوكل فقد شعر بغضب الجماهير لسجن الإمام أحمد وصدق كلامه وأطلق سراحه ورفع مكانته فابتهج الناس كثيرا حتى صاروا يعتقدون في ولايته، ومازال التاريخ يذكره بخير ويثني عليه ثناء عظيما. (1) 


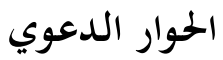

وفيه مباحث

المبحث الأول: بيان أسس الدعوة إلى الله في هذه القصة

المبحث الثاني: بيان أسلوب الدعوة في هذه القصة

المبحث الثالث: بيان أسلوب الموعظة في هذه القصة 


\section{المبحث الأول}

بيان أسس الدعوة إلى الله في هذه القصة

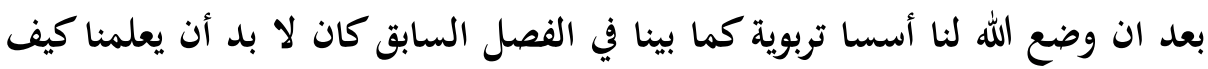

ننفذ ، وما هو قانون التنفيذ ؟ (1)

أول شيء هو الاستقامة. فالله سبحانه بين لنا ذلك في أول حوار في هذه القصة، وهو

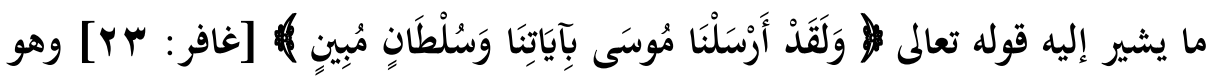
يختصر الحوار الذي في سورة الشعراء :

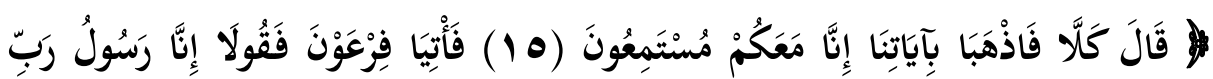

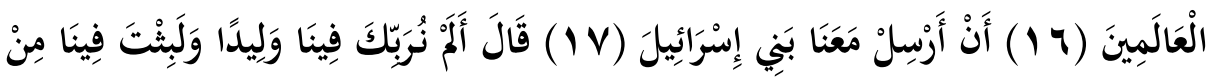

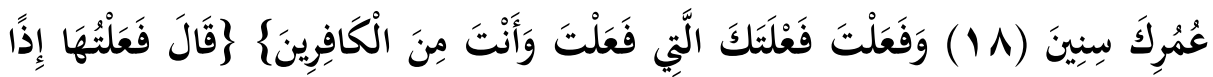

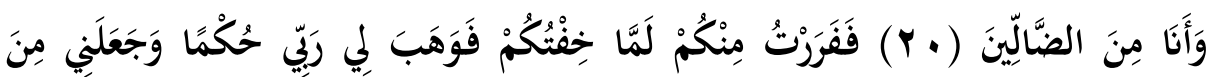

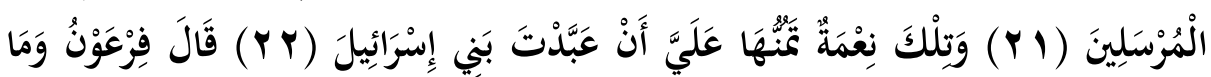

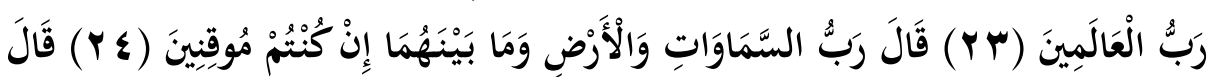

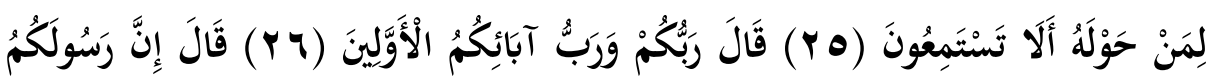

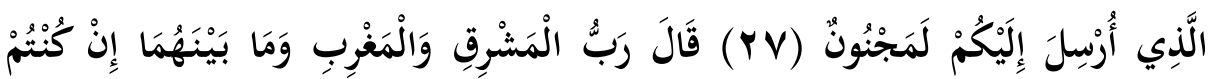

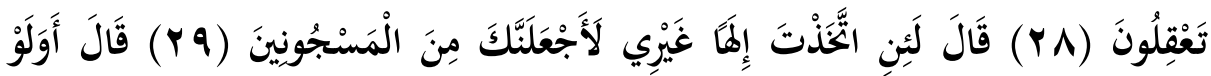

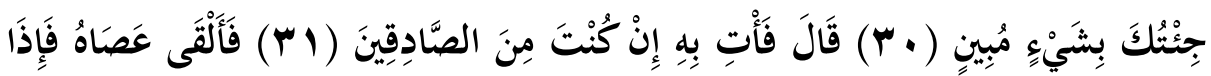

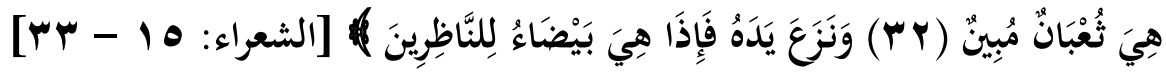

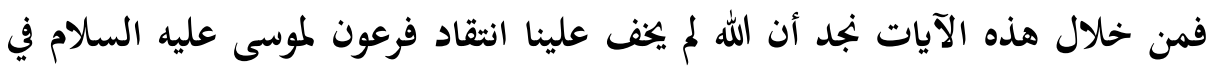
قتله النفس، وهو وإن لم يكن معه حق في ذلك لكن الداعية يجب أن يبتعد عن

(1) واعتمادنا في الحديث هنا على كتاب الله وسنة رسوله صلى الله عليه وسلم بعيدا عن كتب المعاصرين

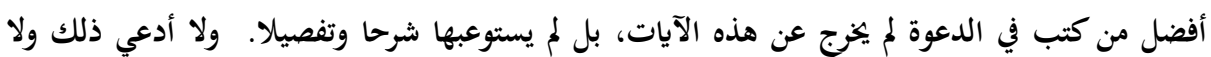
يتسع المقام لذلك، 
الشبهات ويكون مستقيما حتى لا يقال له: انظر إلى نفسك، بل إن فرعون انتقد موسى

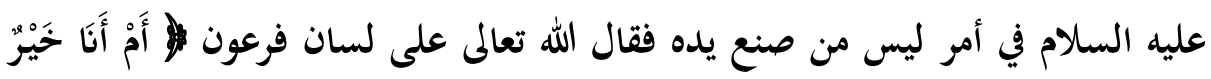

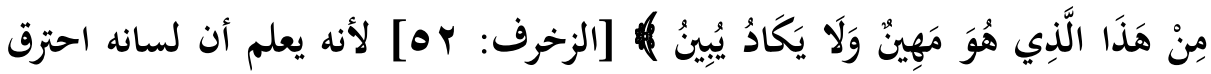

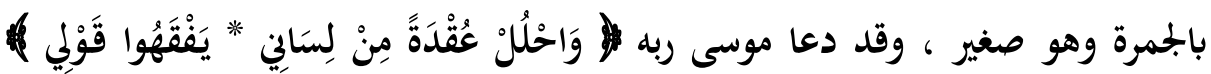

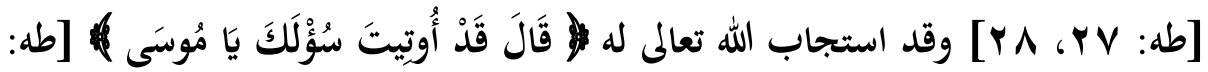

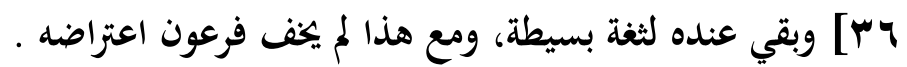
وهو وان اعترض عليه بقتل النفس لكن أجابه بأنه كان لا يدري بأن وكزته ستقنل

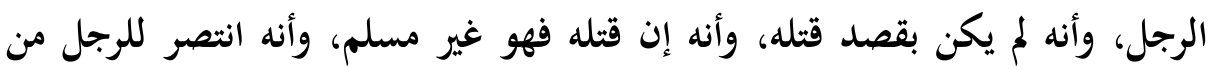

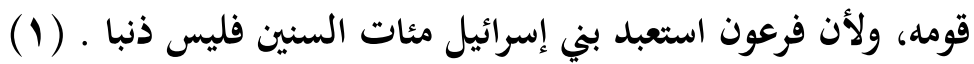
فهذا يدلنا على أن الداعية يجب أن يكون مستقيما صالحا حتى يقبل كلامه، ولا يشغلوه

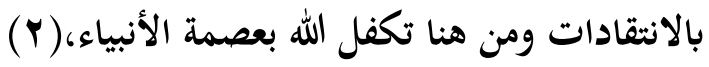
والشيء الثاني: أن يدعو إلى الاعتقاد بوجود الله ووحدانيته وأنه خالق كل شيء ورب كل بله

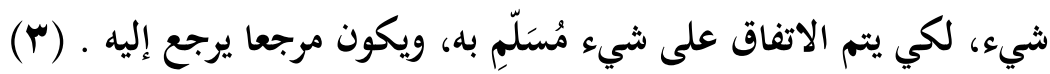

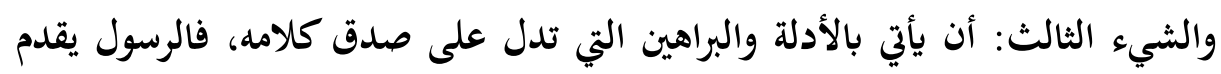
المعجزة والآيات الكونية التي تدل على صدق ادعائه، ورسول الله موسى عليه السلام

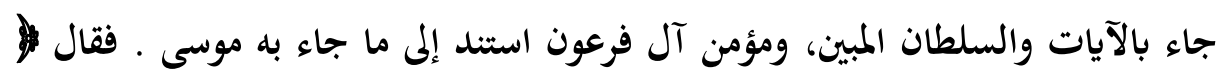

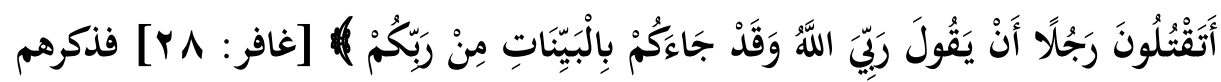

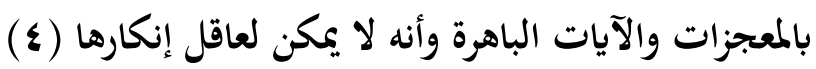

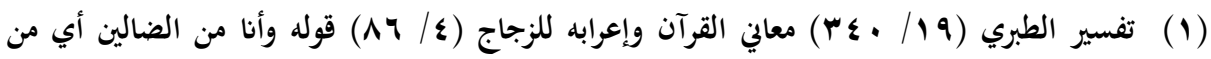

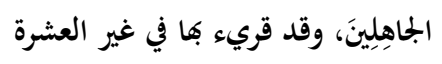

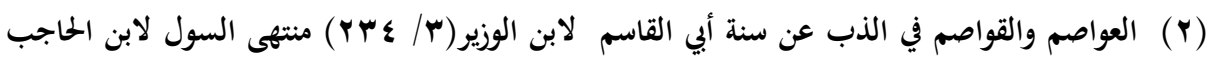

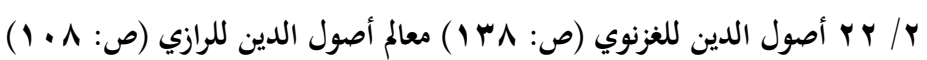

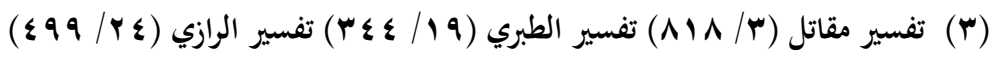

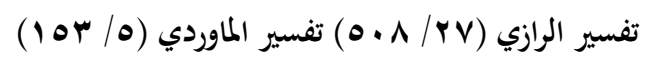


والشيء الرابع: أن يكون عالما، والعالم يستند إلى كل ما جاء به الرسول وإلى العلم

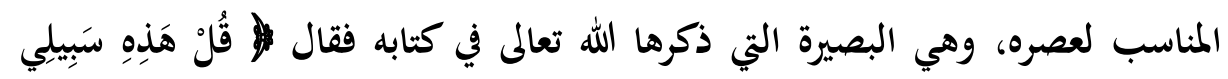

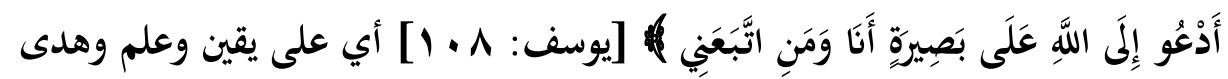

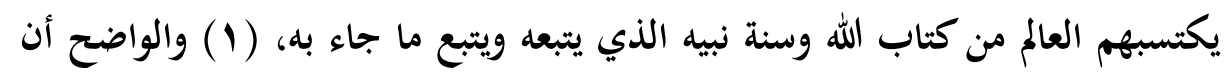

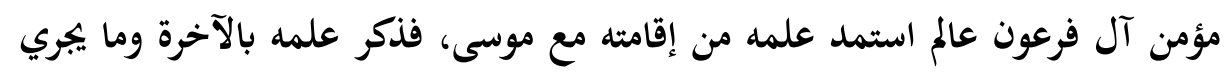

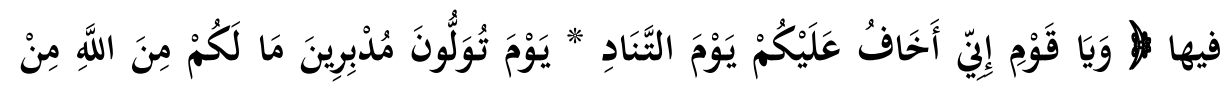

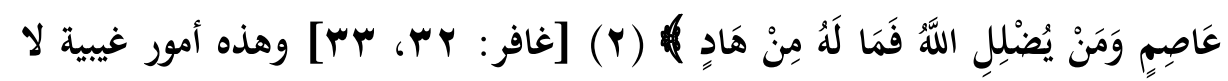

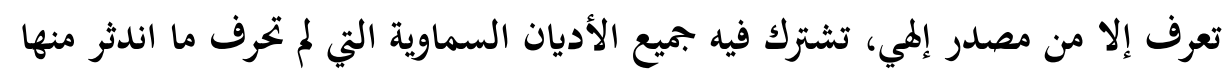

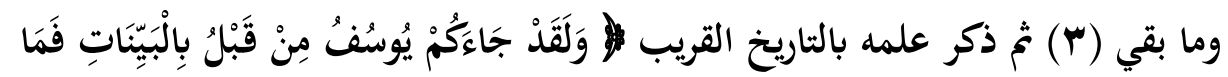

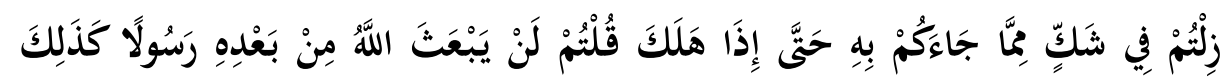

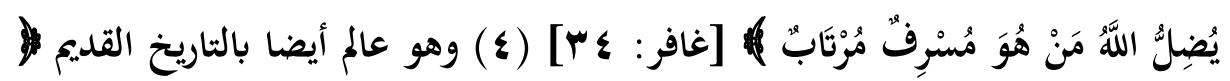

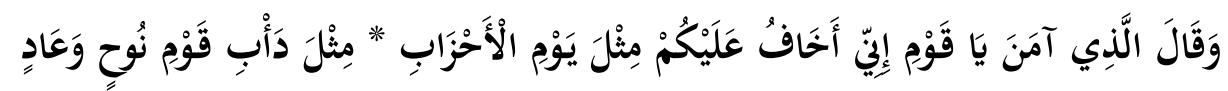

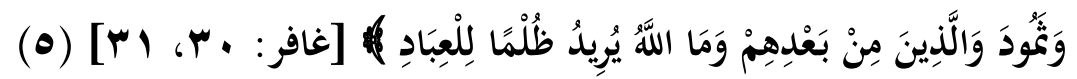
المبحث الثاني

بيان أسلوب الدعوة في هذه القصة

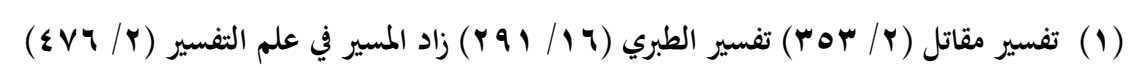

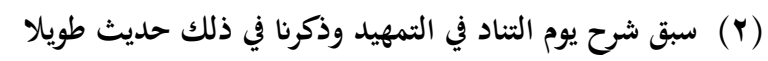

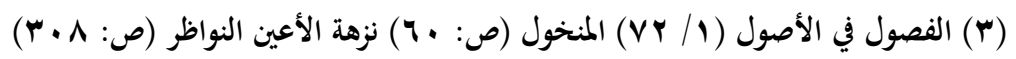

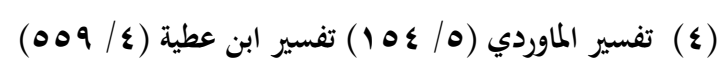

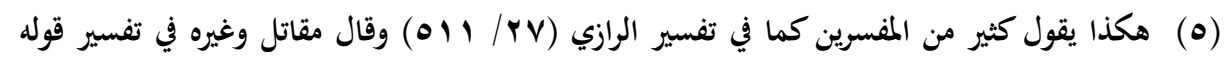

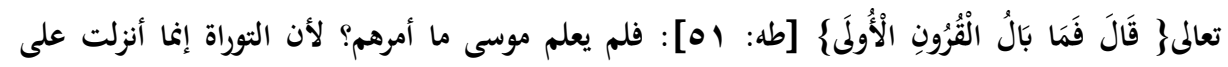

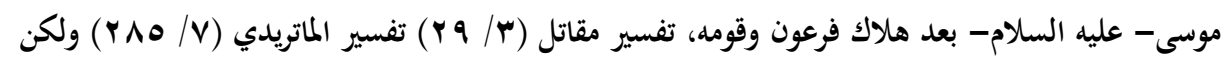

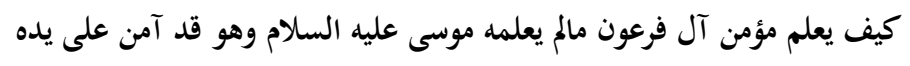


الدعوة لما أساليب خاصة يجب على الداعية أن يلتزم بها، حتى يسمع منه الطرف الآخر

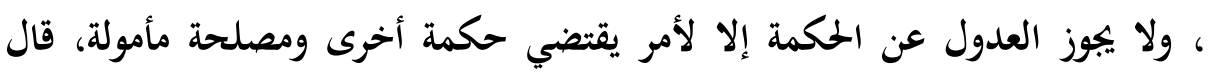

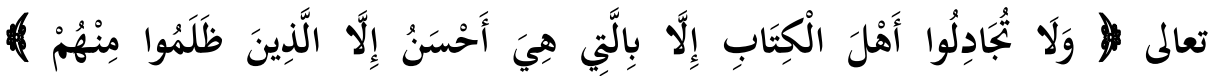
[العنكبوت: 7 \&] إذن فهناك أساليب مرسومة للداعية، وهي: أولاً: الحكمة. وبعضطم يقول إن الحكمة هي العلم، وهو صحيح لكن لها معنى آخر عند

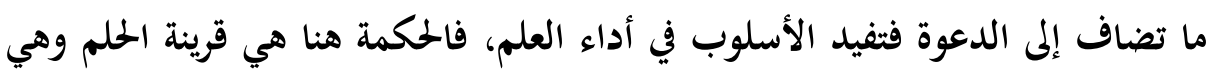

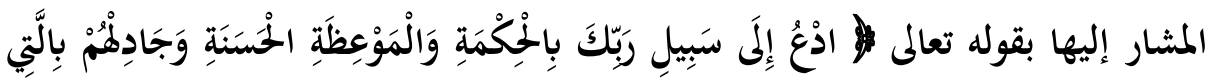

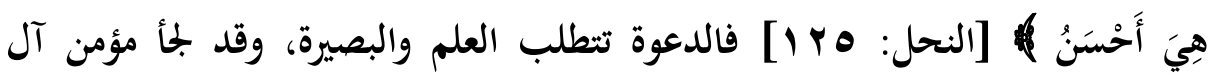

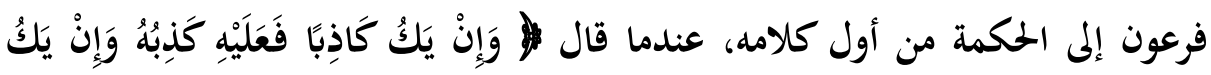

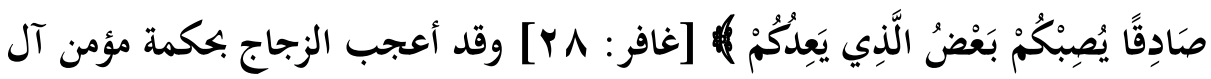

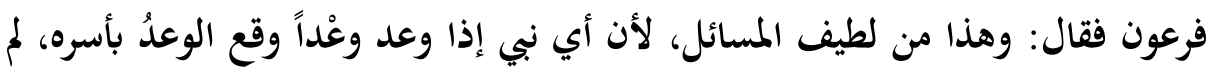

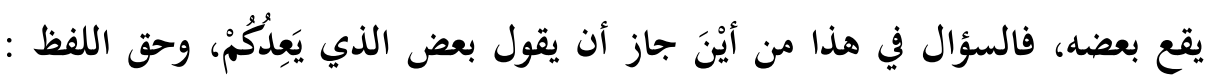

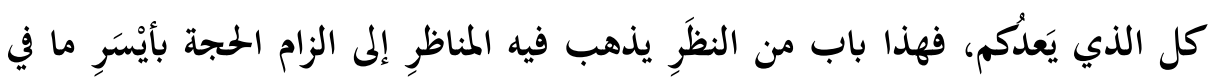

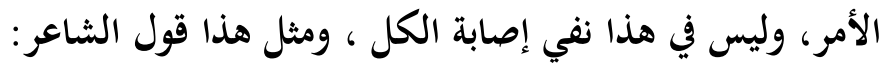

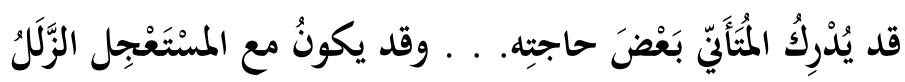

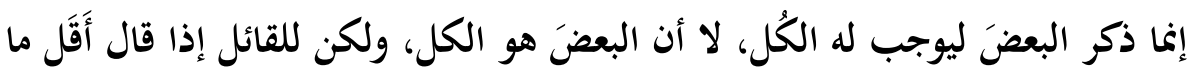
يكون للمتَأني إدراك بعض الحاجة وأقل ما يكون للمستعجل الزل فئل فقد أبان فضل المتأين

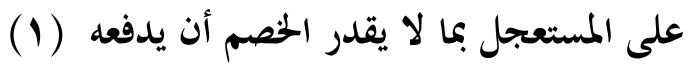

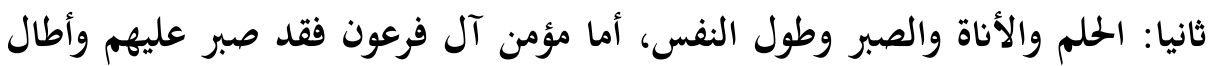
النفس كثيرا حتى لتجد كلمة (يا قوم) كررها خمس مرات:

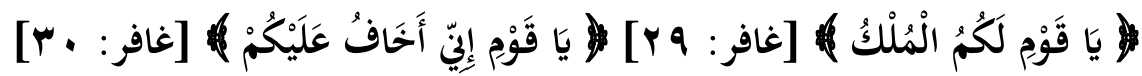




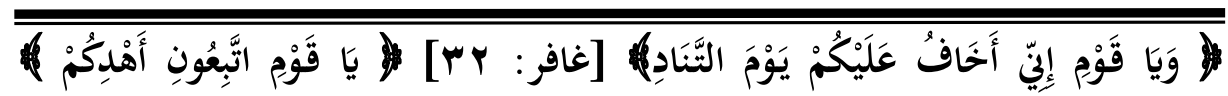

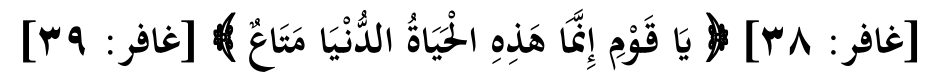

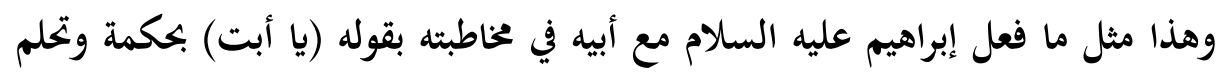

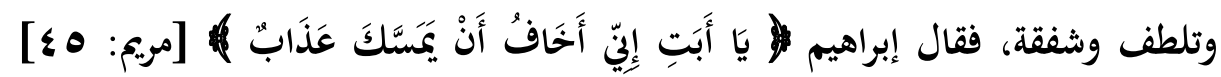

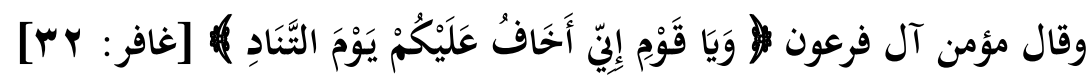

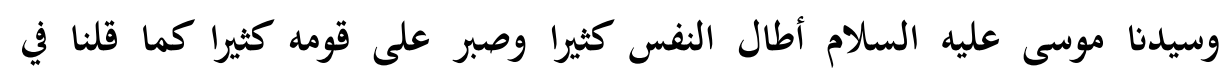

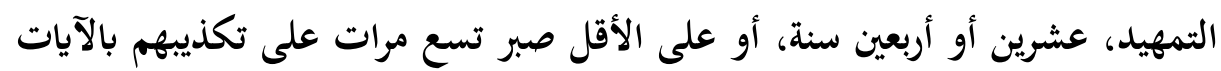

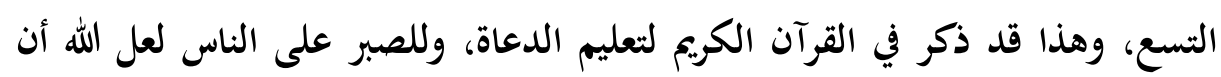

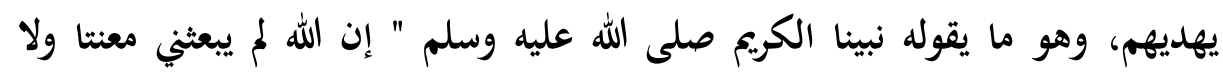

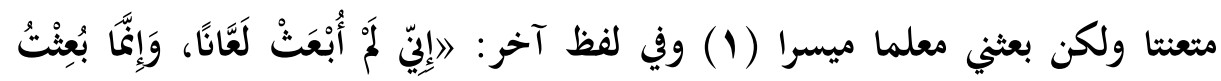

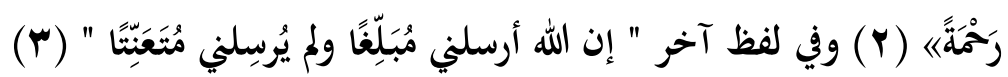

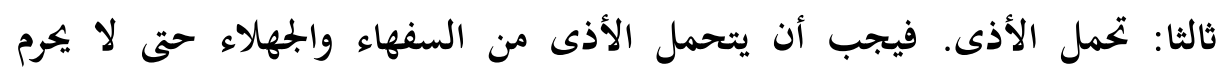

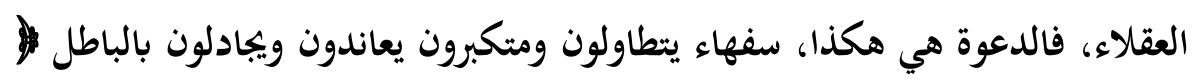

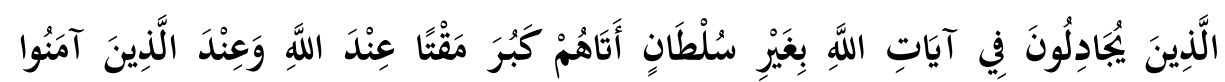

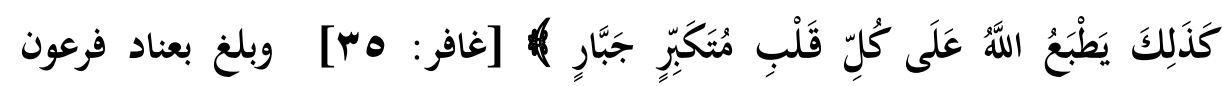

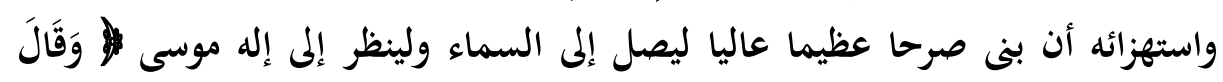

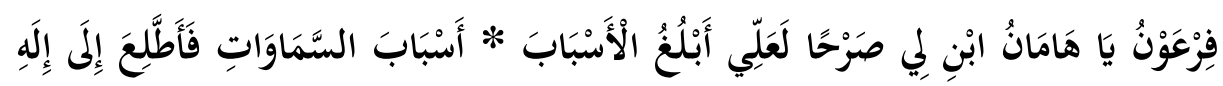

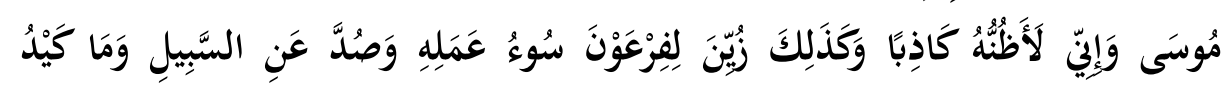

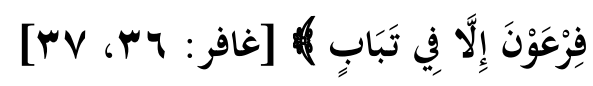

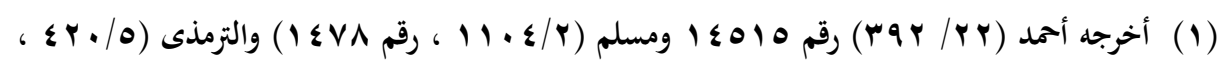

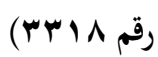

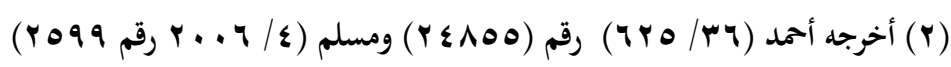

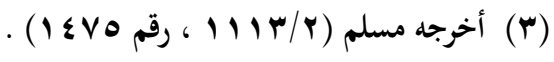




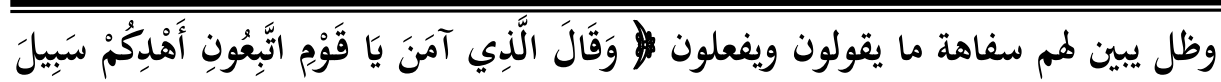

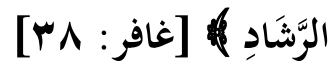

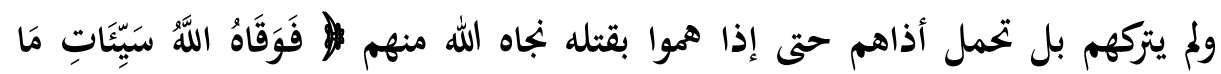

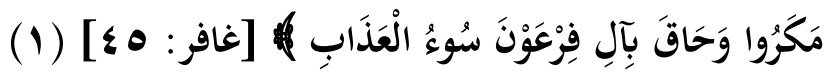

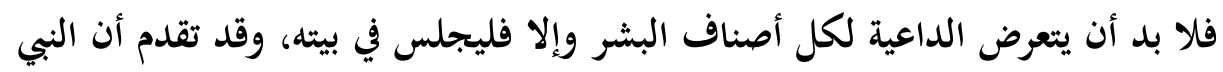

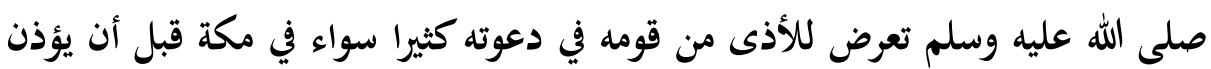

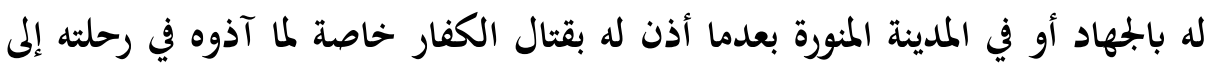
الطائف ودعا دعاءه المشهور (Y) فنزل ملك الجبال ومعه إذن بأن يطبق عليهم الجبال

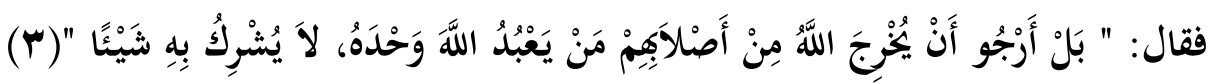

(1) التفسير الوسيط للواحدي (ع / م 1) قال: ثم خرج المؤمن من بينهم، فطلبوه فلم يقدروا عليه، تفسير

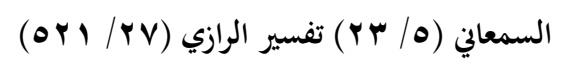

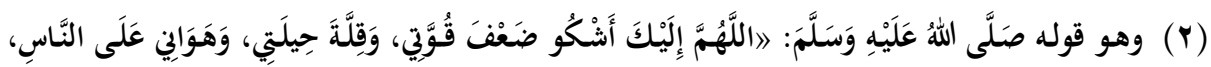

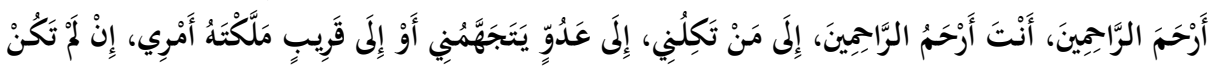

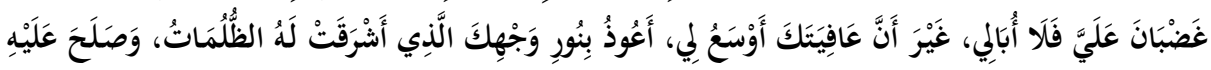

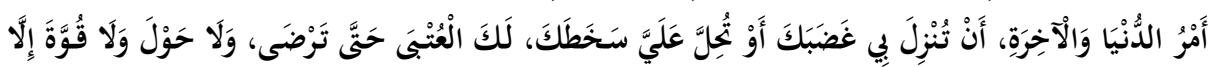

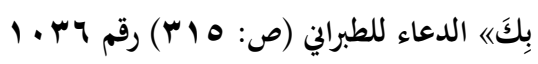

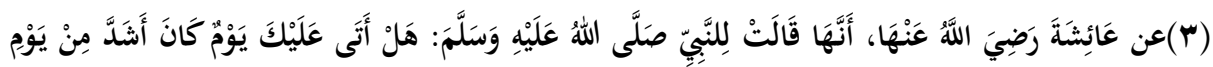

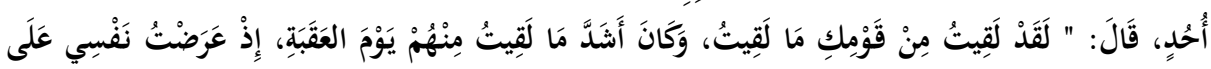

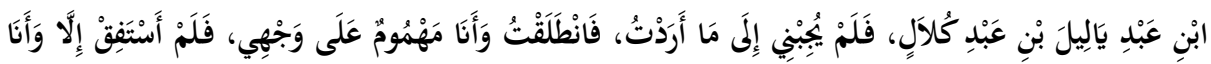

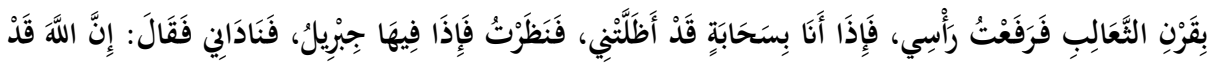

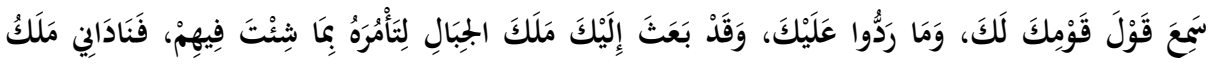

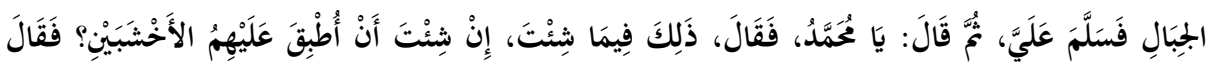

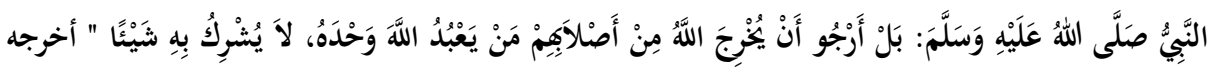

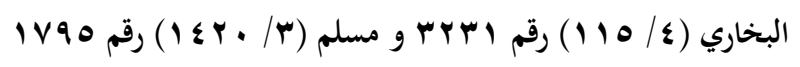


وفي أحد لما شجوا وجهه وعقبه الشريفين فقال" اللهم اغفر لقومي فإغم لا يعلمون

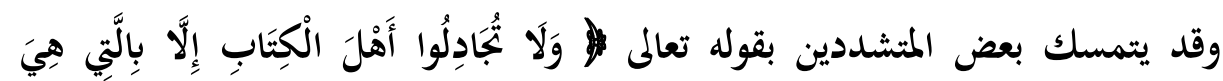

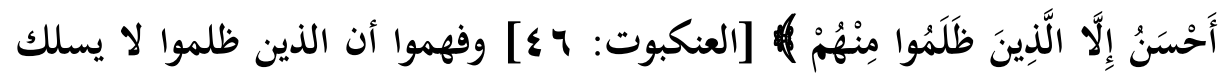

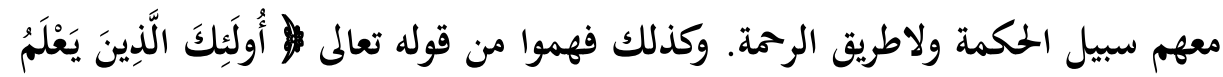

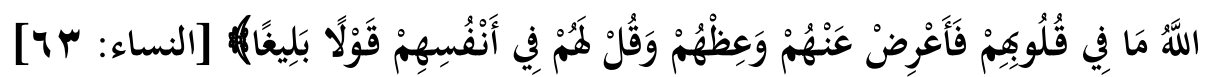

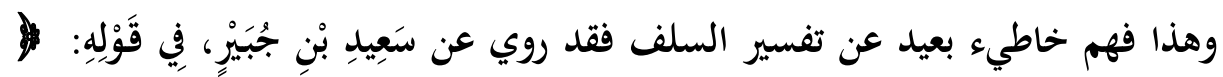

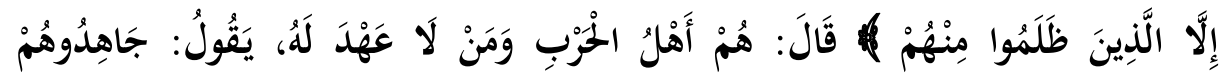

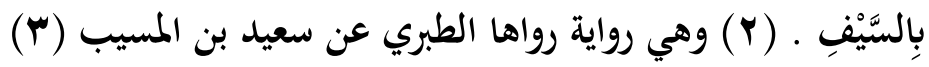

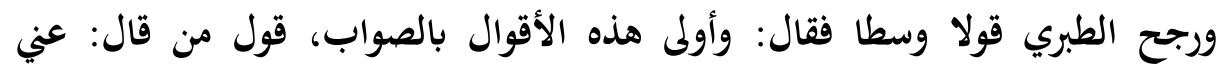

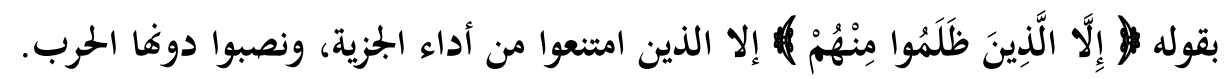

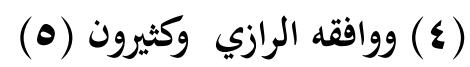

ومن هنا فلا يجوز مجابهة الناس في الدعوة ولا مقاتلة المخالفين، فإنها حينئذ تكون فتنة عظيمة ، إما أن تؤدي إلى قتل الداعية نفسه أو لفتنة داخل الدولة نفسها بتقاتل فئتين

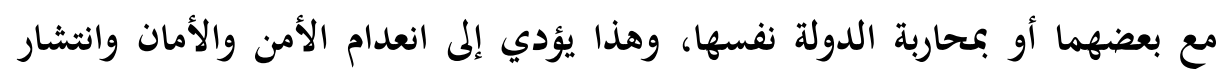

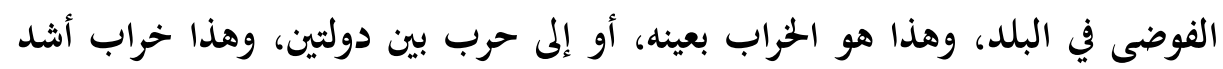
وفوضى أخطر .

$$
\begin{aligned}
& \text { (1) تقدم تخريجه في المبحث الأول من الفصل الأول }
\end{aligned}
$$

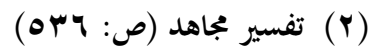

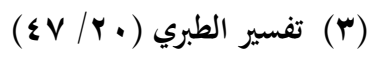

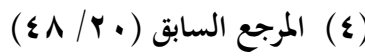

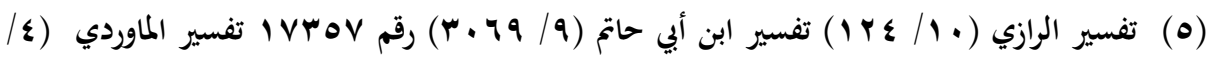

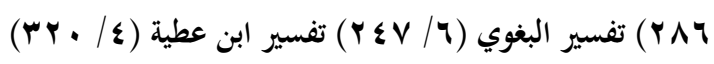


$\mu . \Lambda$

وكل ما ييري اليوم في المنطقة العربية والإسلامية أسبابه الخطأ في الدعوة، حيث اعتبر الدعاة أنفسهم مقاتلين يفرضون رأيهم بقوة السلاح، واستغلوا انشغال الحكام عنهم أو الو جهل العقلاء بعواقب الأمور ، فقامت الفتنة أولا بين التيارات المختلفة ثم تطورت

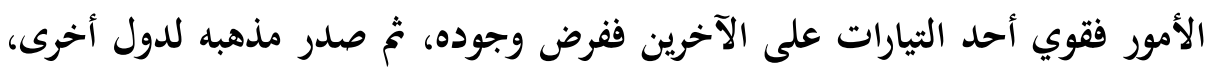

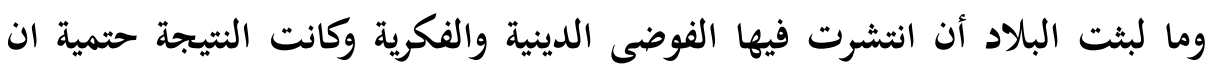

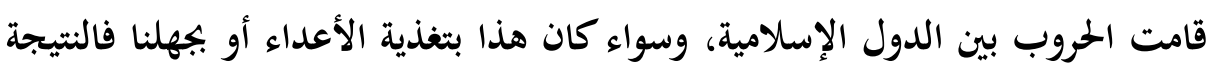
واحدة .

وهي ما نعيشه اليوم بكل الدمار الذي طال المنطقة، بل أقول إن الدمار لحق العالم كله ، وأصبحنا اليوم نعيش أسوأ ظروف مرت علينا في التاريخ كله. 


\section{المبحث الثالث}

بيان أسلوب الموعظة في هذه القصة

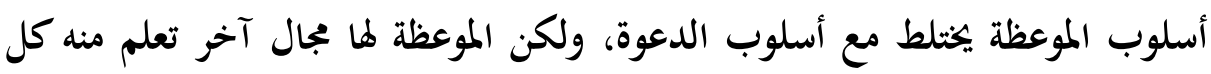

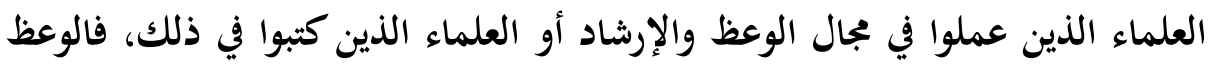

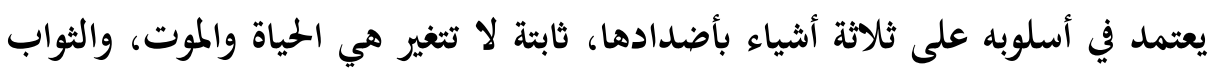
والعقاب، والحنة والنار ، وهذه الأشياء هي التي ذكرها الله تعالى في قصة مؤمن آل لئل فرعون .

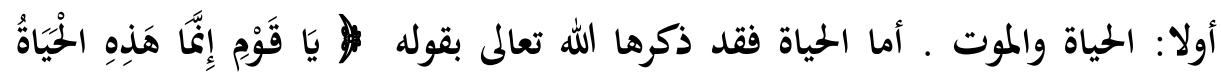

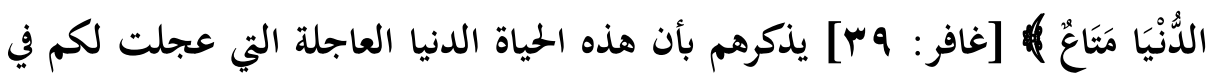
هذه الدار متاع تستمتعون بما إلى أجل أنتم بالغوه، وأفا فانية توشك على لألى الانقضاء

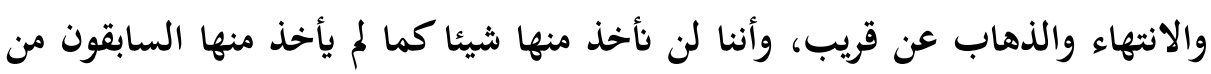

الجبابرة والمعاندين وأتباعهم، (1)

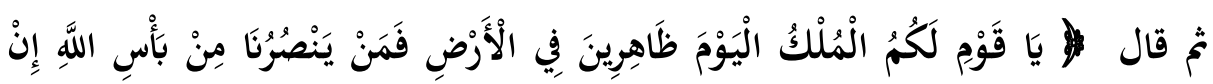

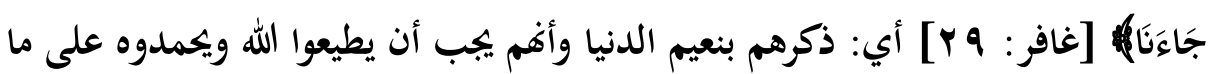
أنعم به عليهم، قبل أن يحل بأس الله وهو الموت على غضب الله الله ومعصيته، فإِ المعاند هو الذي لا يستحق رحمة الله في الدنيا. ثم ذكرهم بما حل بالأمم السابقة وأن عنادهم ووقوفهم ضد الدم الأنبياء ورسالة السماء لن

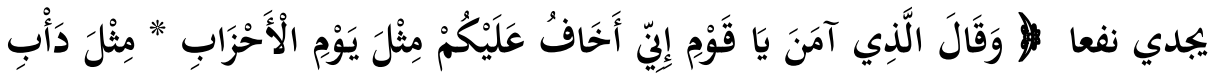

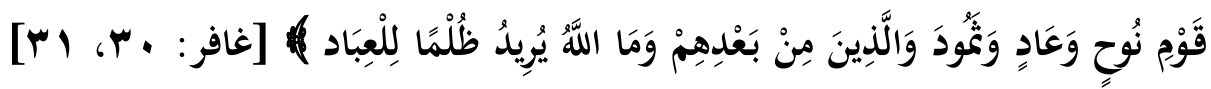

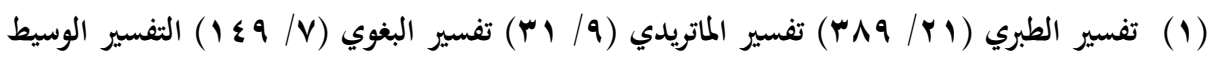

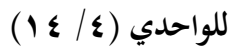

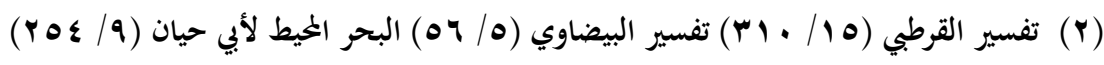


وبين لمم أن الصراع بين الحق والباطل نتيجته انتصار الحق مهما علا دخان الباطل وارتفع زبده، وأن النجاة مع الحق :

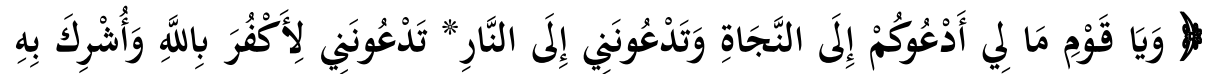

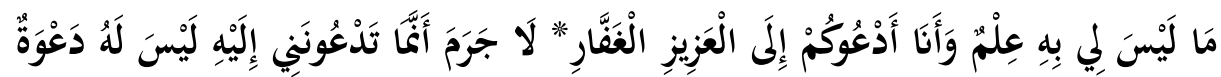

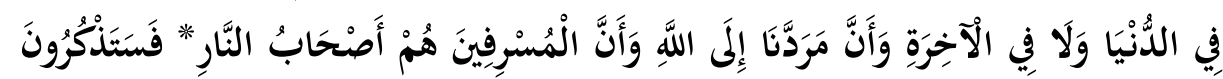

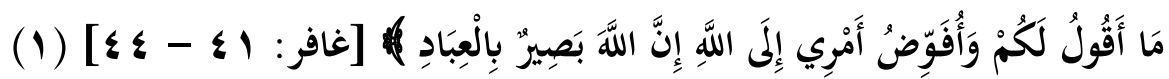

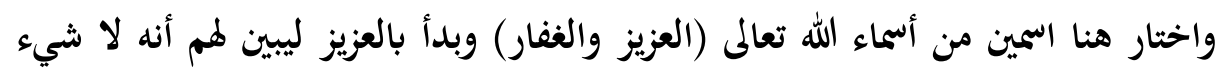

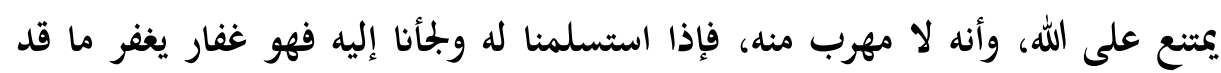
كان. وقد بين لمم عجب حاله وحالهم كيف يريد لهم الحير والنجاة وهم يتقحمون في النار .

ومثل هذا قوله صلى الله عليه وسلم " إنَّمَا مثلي وَمثل النَّاس كَمثل رجل استوقد نَارا،

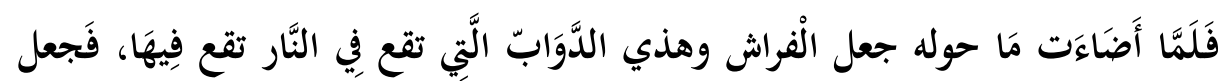

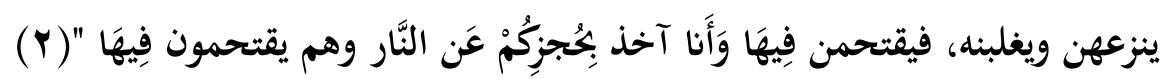
ثانيا: الثواب والعقاب. فالواعظ صاحب الموعظة الحسنة مهمته بيان ثواب الله على فئلى الطاعة وعقابه على المعصية، دون دخول في الحخلافيات، وهذا ما صرح به مؤمن آل

فرعون: - n

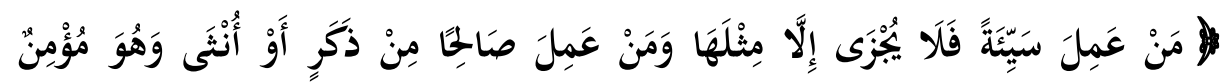

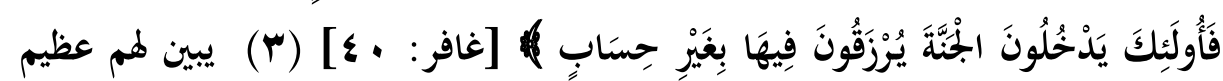

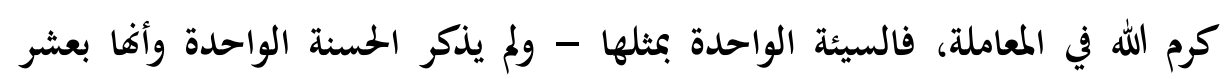

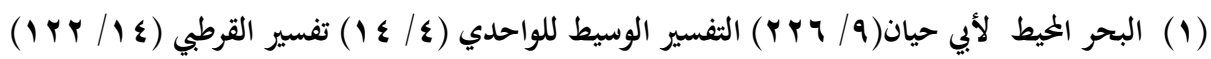

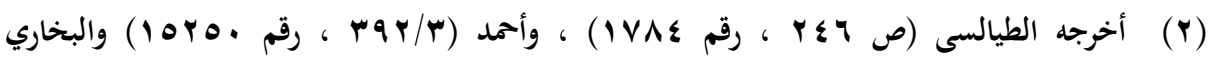

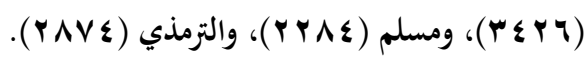

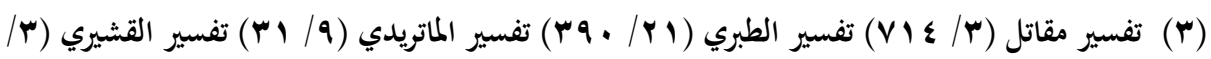


أمثالها لأنما خاصة بأمة محمد صلى الله عليه وسلم - (1) وإنما ذكر مجمل العمل الصالح

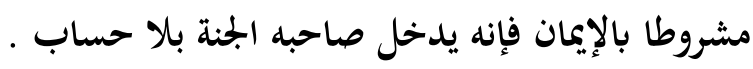

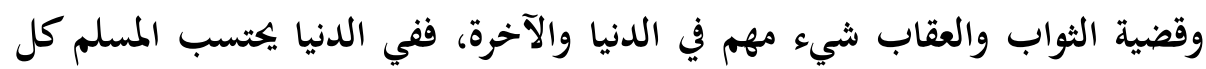
عمل لله رجاء ثوابه، ويبتعد عن الذنوب والحطايا قدر إمكانه خوفا من عقابه، ولا يؤذي الهي أحدا لأنه معصية لله، وكذا الشرع عندما يكون له الحكم يكافيء الخحسن وينشر إحسانه، ويعاقب الجرم ويضرب على يده، لكي يأمن الناس على دمائهم وأموالهم، فمن أمن لهن

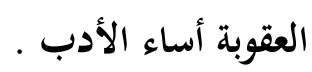
الثالث: الجنة والنار ـ وهذا صحيح أنه من أركان الإيمان ومرتبط بالعقيدة لكنه شيء

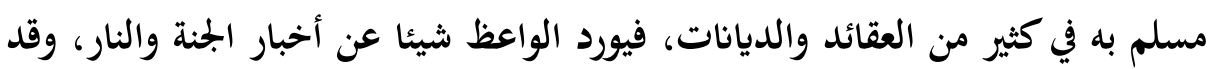

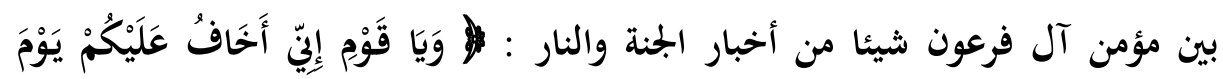

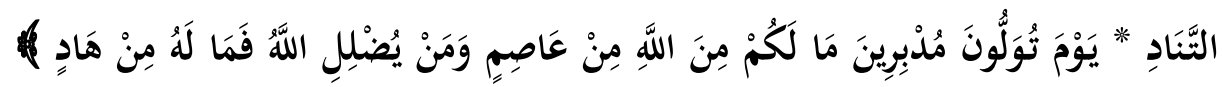

] (غافر:

وتعبيره عن يوم القيامة بيوم التناد تعبير أكثر من رائع، لأنه يشمل كثيرا من مواقف

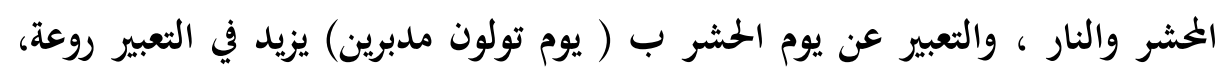

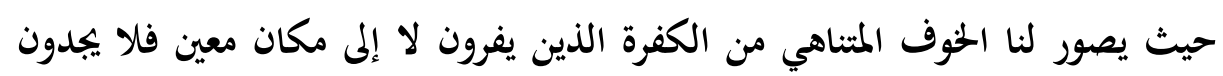

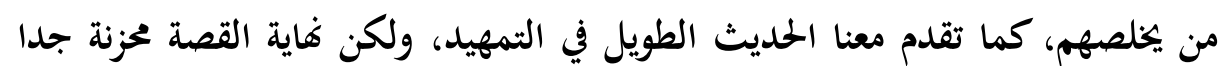

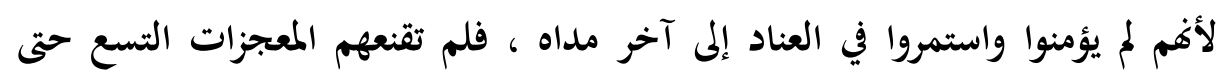
آخرها:

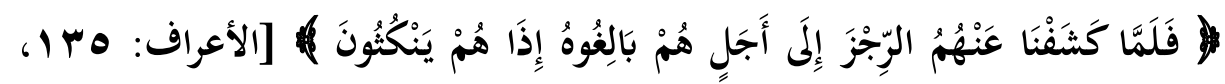

(r) $[$ I M

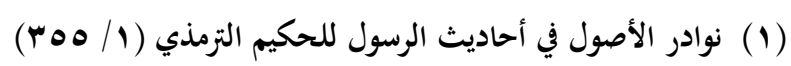

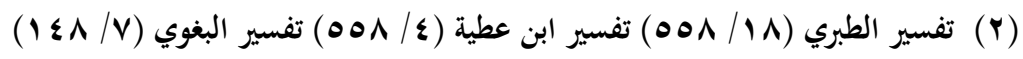

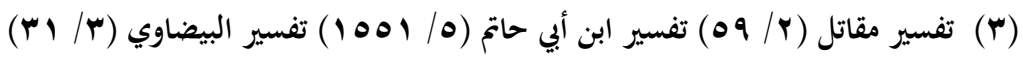


ولم يرضوا حتى بإرسال بني إسرائيل معه، وأعلن فرعون النفير العام:

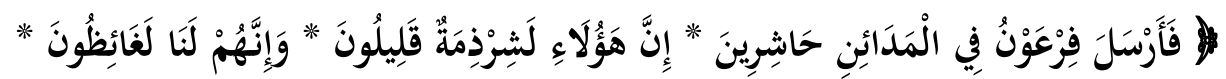

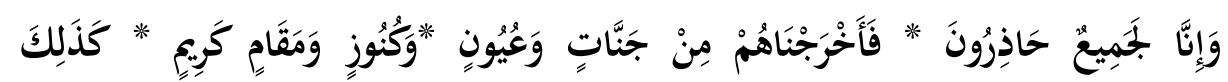

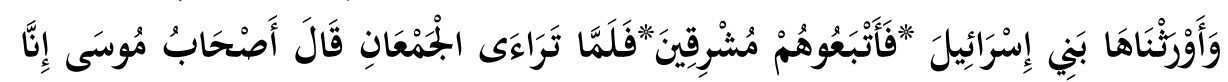

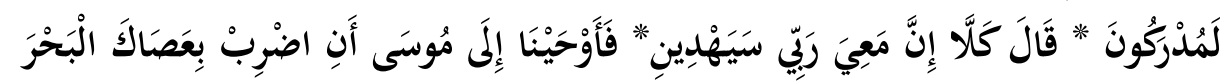

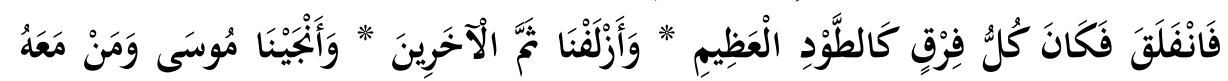

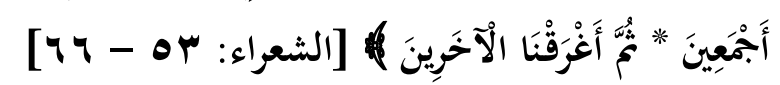

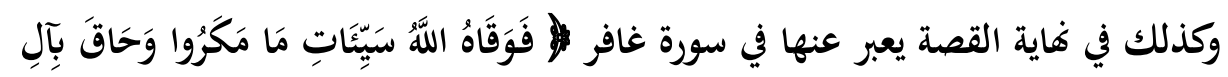

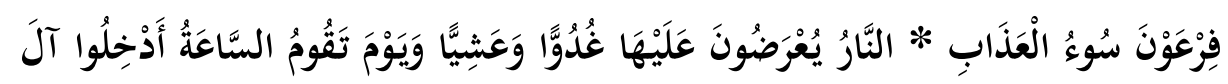

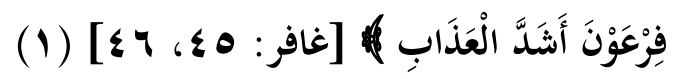

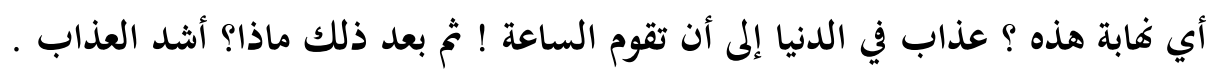

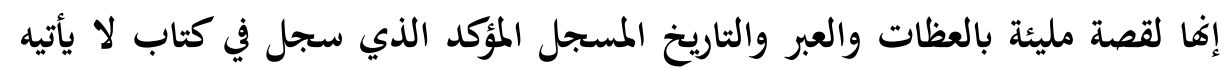

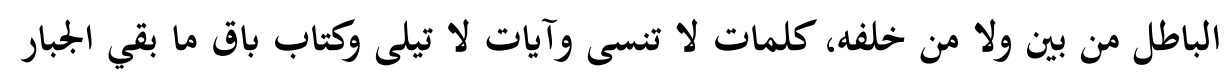

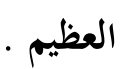

اللهم بفضلك اجعلنا مؤمنين مستسلمين ولا تجعلنا من المتكبرين المعاندين. وصلى الله على سيدنا حممد وعلى آله وصحبه أجمعين .

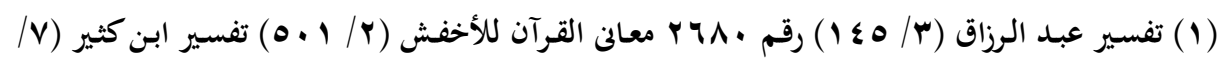




\section{الخاتمة}

بعد أن انتهينا من هذا البحث الذي اشتمل على قصة مؤمن آل فرعون، وهي من أحسن القصص ، مليئة بالعبر ، تستحق أن يكتب فيها مجلدات عديدة ، وكل التحل ما كتبناه ما هو إلا غيض من فيض، وإشارات إلى مكان العظمة وموطن الروعة، ونرفع أيدينا

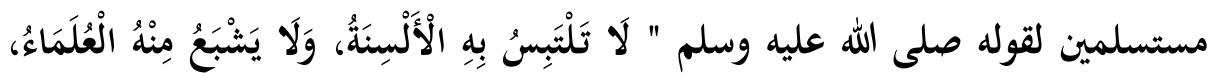

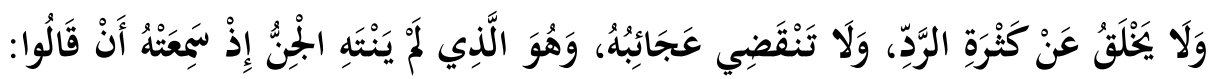

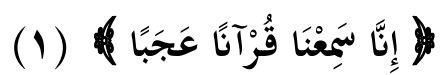

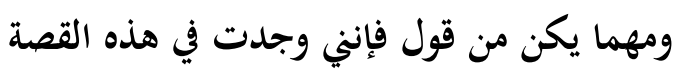

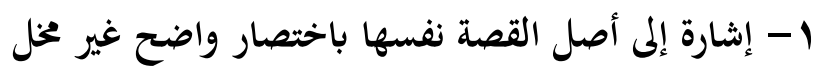
ץ- عرضٌ أكثر من رائع لقصة مؤمن آل فرعون في سورة غافر والتي تسمى باسمه ( سورة مؤمن )

ب- تعليم للعلماء والفصحاء كيف يكون الحوار الهاديء القوي ع- تعليم للعلماء كيف تكون المواقف وكيف يكون العالم المجاهد بكلمة الحق

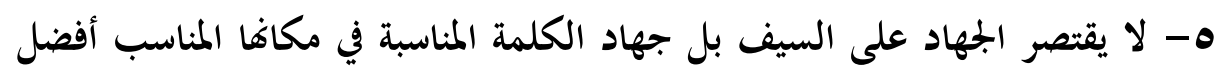

$$
\text { من الجيوش الجرارة }
$$

ج- هذه القصة دستور دعوة تعلم الداعية كيف يختار المواقف

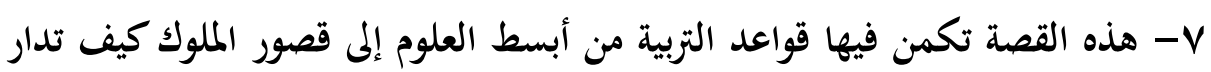

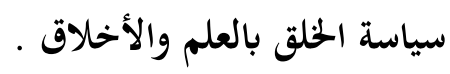
^- هذه القصة ترينا قدرة الله وإرادته وأنه لا أحد يستطيع مغالبة القدرة الإلمية . 9- هذه القصة تغصب المثدبر أن يقرأها بتأنِ وتمعن

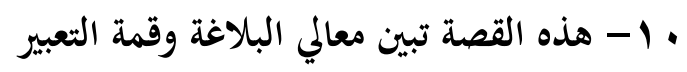

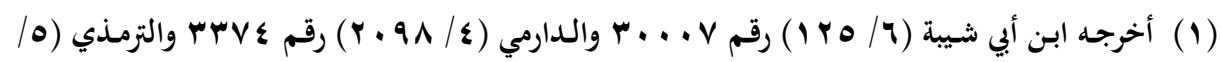


11 - هذه القصة تجمع علوم الدنيا والآخرة r ا - هذه القصة ترينا كيف تكون نهاية كل من يخالف قانون المنهج الإلهي الذي كفل

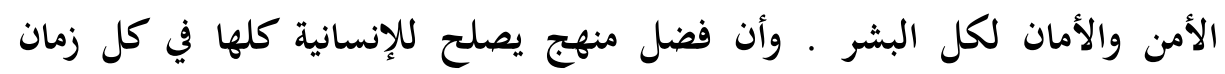
ومكان . rا - أن عذاب القبر ثابت يجب أن نعتقد أن الكافر يعذب في قبره في الدنيا ولكن حجب الله عنا رؤية ذلك لكي تسير الحياة . التوصيات أولا: أوصي كل عالم أن يعيد قراءة هذه القصة ألف مرة ثم يبين معانيها للشباب ألف

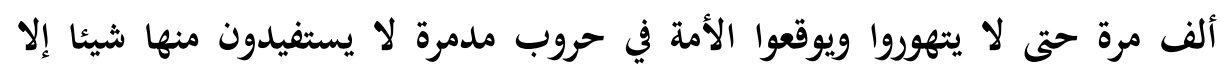

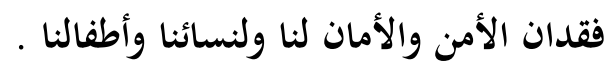
ثانيا: أوصي الجامعات الإسلامية أن يكلفوا الباحثين في الكتابة في هذه القصة ـ ـ فهي تحتمل رسائل في الماجستير و الدكتوراة.

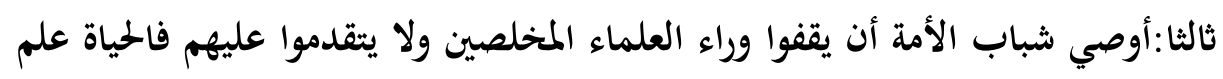
وخبرة . رابعا: أون يتدبر كتاب ربه ففيه غذاء الروح والعقل. وفيه حل لجميع مشاكل الحياة

$$
\text { وصلى الله على سيدنا محمد آله وصحبه أجمعين . }
$$




\section{فهارس المصادر}

ا- أخلاق العلماء للآجري: أبو بكر محمد بن الحسين بن عبد الله الآجُرِّيٌُ البغدادي

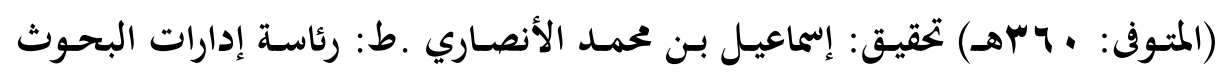

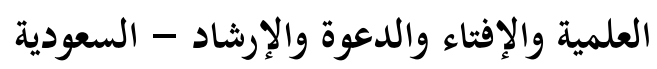
ץ- الآداب للبيهقي: أحمد بن الحسين بن علي بن موسى الحُسْرَوْجِردي الحراساني، أبو

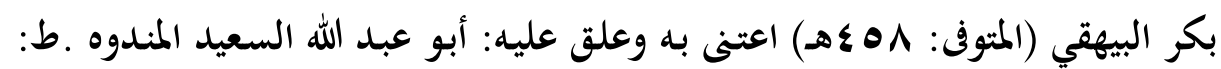

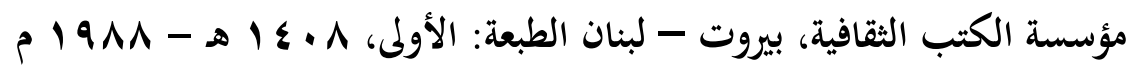

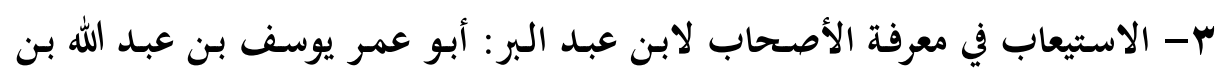

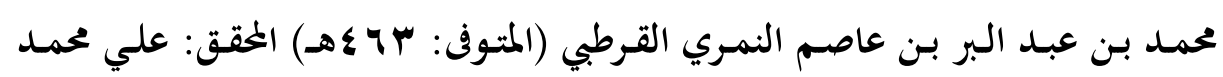

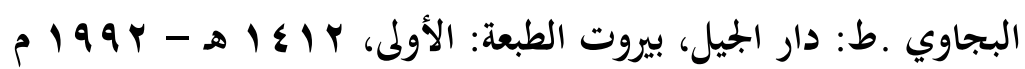

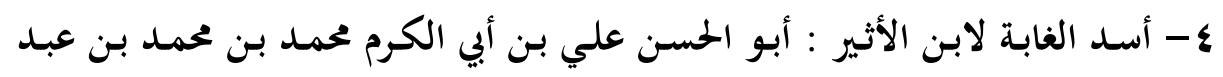

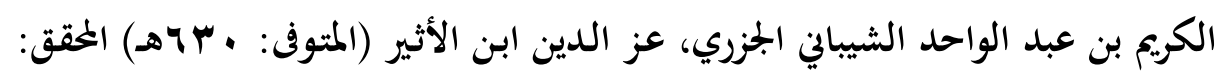

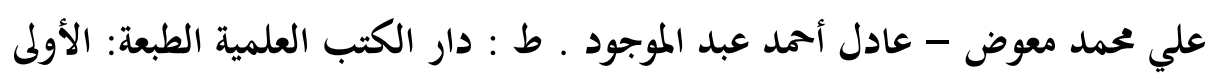

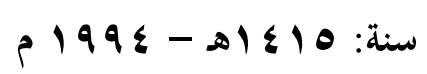

ه- أصـول الدين للغزنوي: جمـال الدين أحمــ بـن محمـد بـن سـعيد الغزنوي الحنفي (المتوفى: بهـهـ) المحقق: الدكتور عمر وفيق الداعوق . ط : دار البشائر الإسلامية -

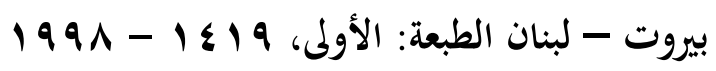

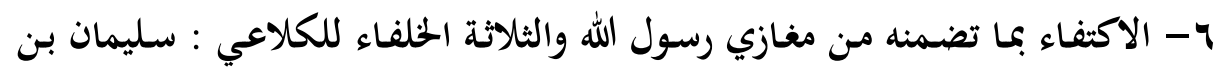
موسى بـن سالم بـن حسان الكلاعي الحميري، أبو الربيع (المتوفى: ع بآهـ) ط : دار

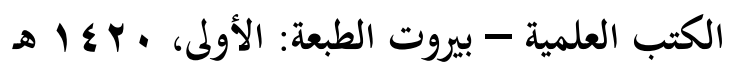

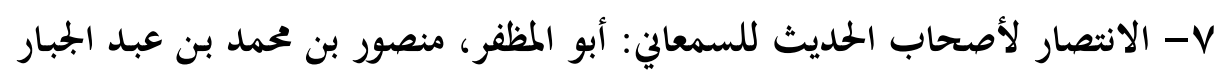

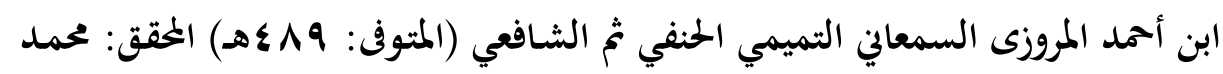

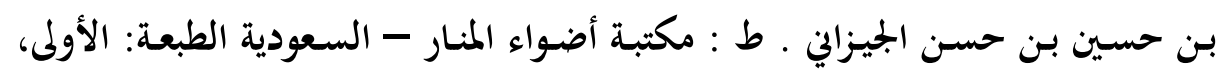


1- البحر الخيط لأبي حيان : محمد بن يوسف بن علي بن يوسف بن حيان أثير الدين

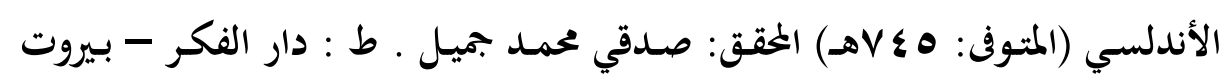

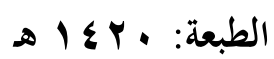

9- البحر المديد لابن عجيبة : أبو العباس أحمد بن محمد بن المهدي بن عجيبة الحسني

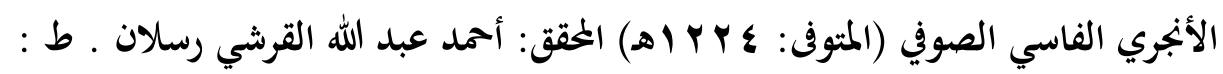

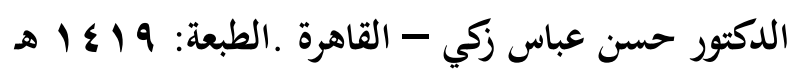

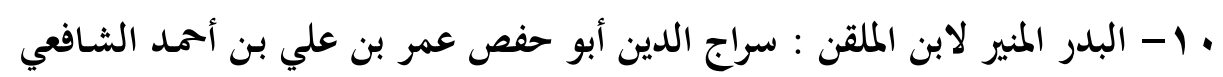

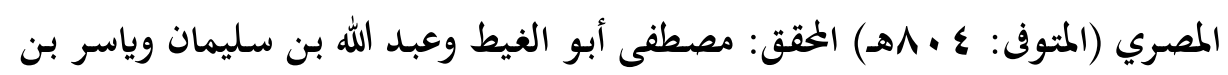

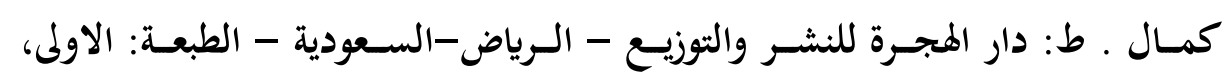
مr...

11 - التاريخ الكبير للبخاري : محمد بن إسماعيل بن إبراهيم بن المفيرة البخاري، أبو

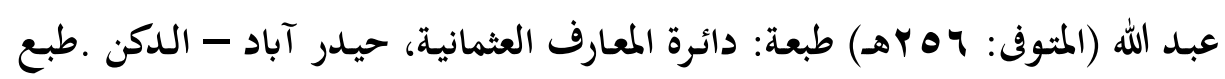
تحت مراقبة: محمد عبد المعيد خان

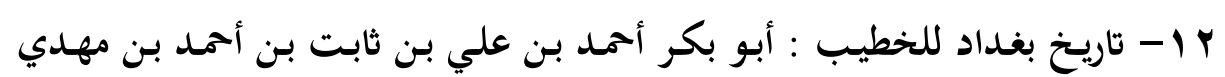

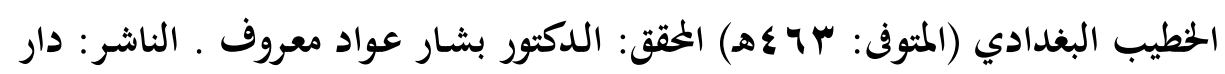

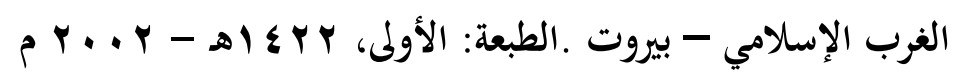

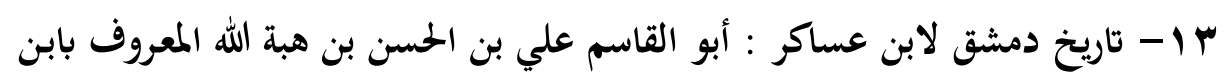

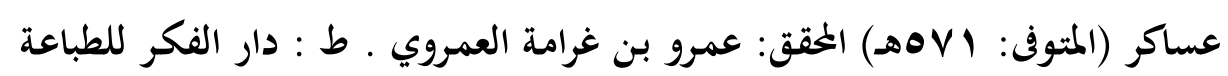

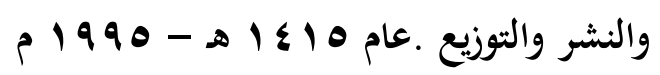
ع ا- ترتيب الأمالي الحميسية للشجري : يهيى (المرشد بالله) بن الحسين (الموفق) بن

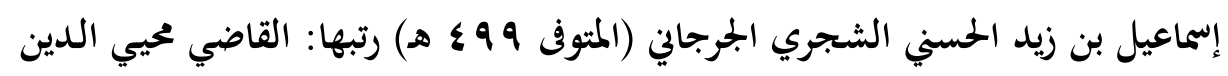

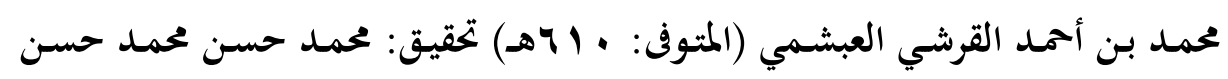

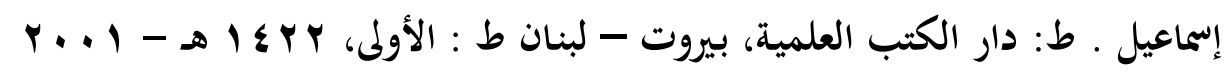


10 - تفسـير ابـن أبي حساتم: أبـو محمـد عبـد الرحمن بـن محمـد بـن إدريس بـن المنــر

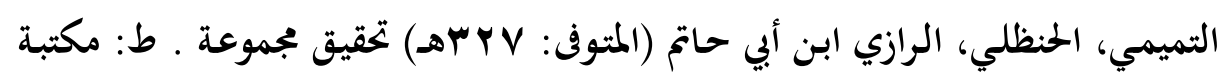

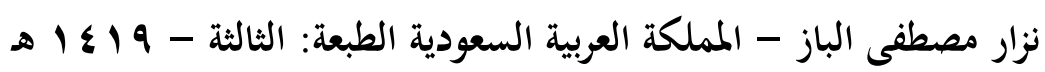
17

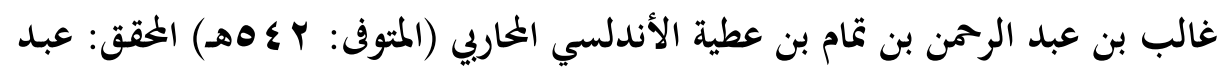

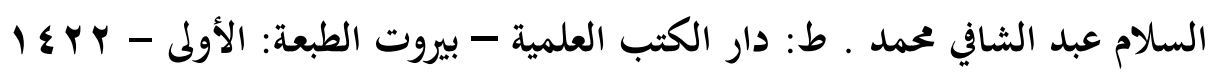

IV - تفسـير ابـن فورك: محمـد بـ الحسـن بـن فورك الأنصـاري الأصسبهاني، أبو بكر (المتوفى: 7 • عهـ) تحقيق: علال عبد القادر بندويش (ماجستير) ط : جامعة أم القرى -

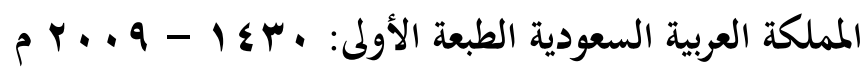

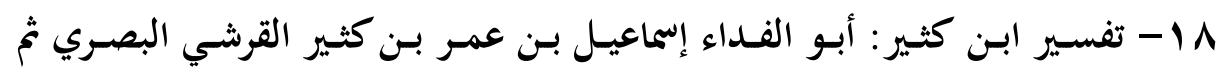

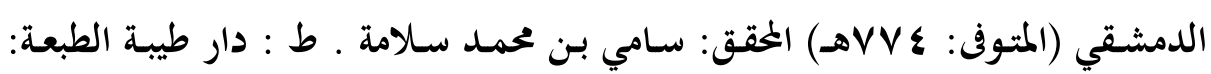

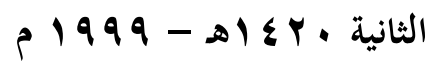
9 1 - تفسير البغوي ( معالم التنزيل في تفسير القرآن ) أبو محمد الحسين بن مسعود

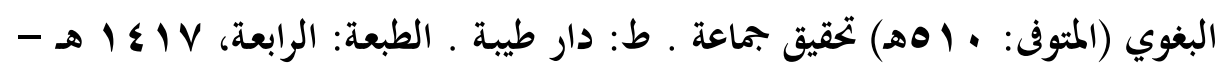
م 199V • •

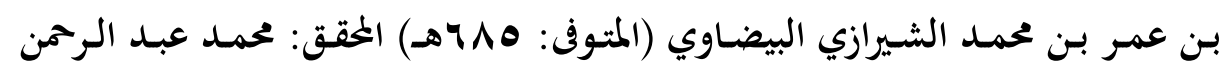

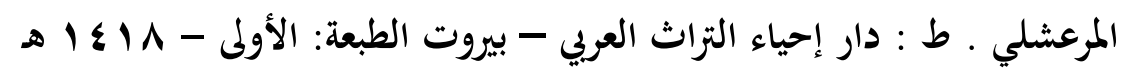

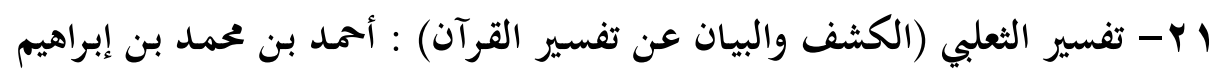

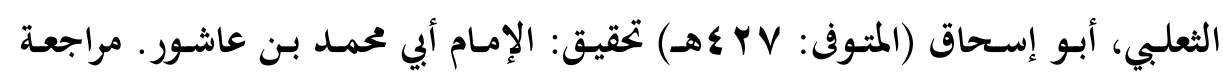

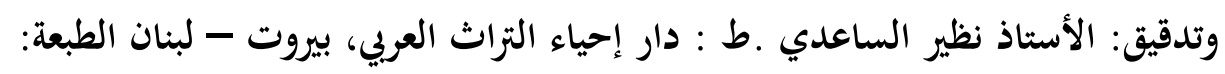

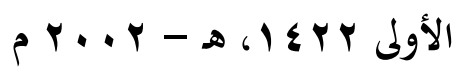


Y Y - تفسير الرازي ( مفاتيح الغيب أو التفسير الكبير ): أبو عبد الله محمد بن عمر بن الحسن بـن الحسين التيمي الرازي الملقب بفخر الدين الرازي خطيب الري الري (المتوفى:

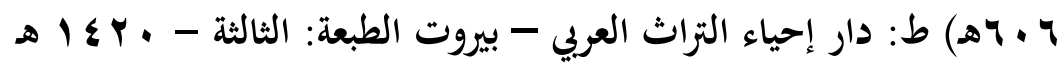

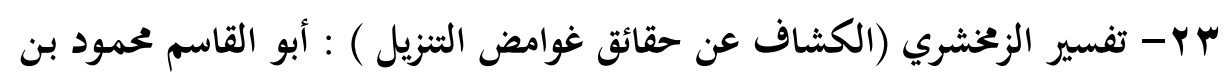

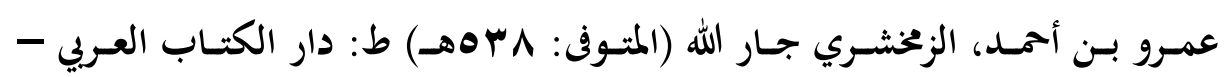

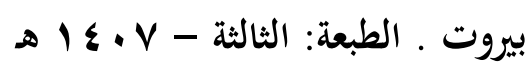

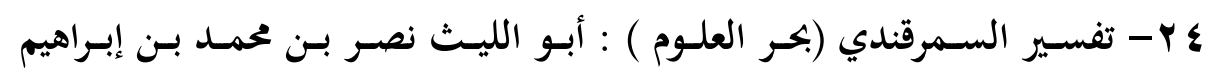

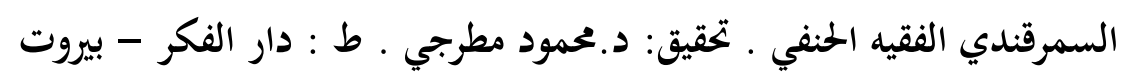

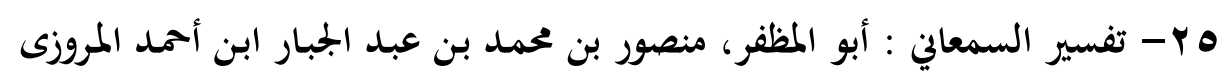

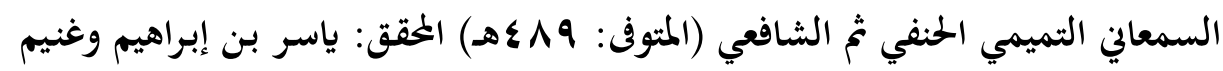

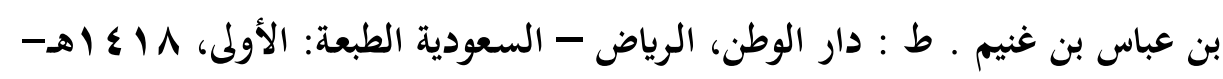
p) $99 \mathrm{~V}$ צ - تفسير الطبري ( جامع البيان عن تأويل آي القرآن) : محمد بن جرير بن يزيد بن

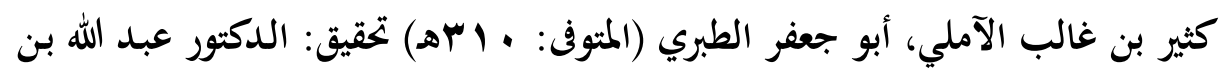

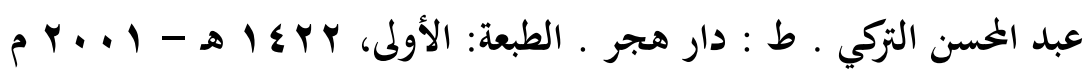

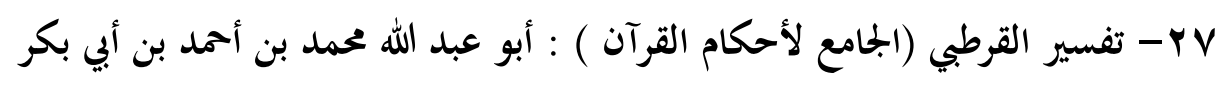

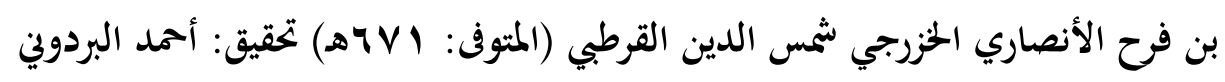

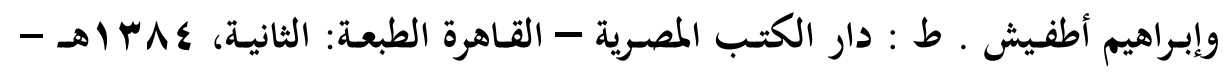
م $197 \varepsilon$ ^ץ - تفسـير القشـيري(لطائف الإشـارات ) : عبـد الكـريم بـن هـوازن بـن عبـد الملكك

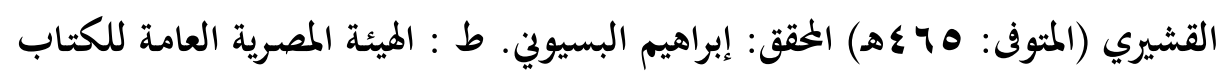
- مصر . الطبعة: الثالثة 


\section{piq}

9 Y - تفسير الماتريدي ( تأويلات أهل السنة ) : محمد بن محمد بن محمود، أبو منصور

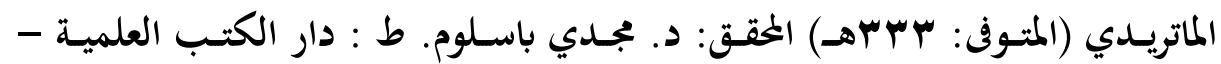

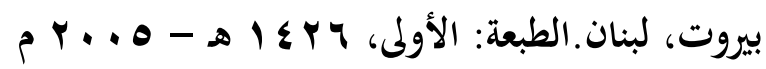

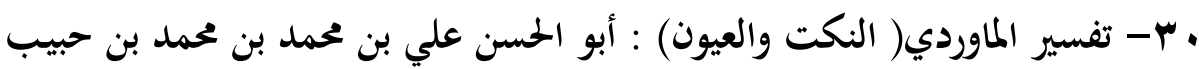

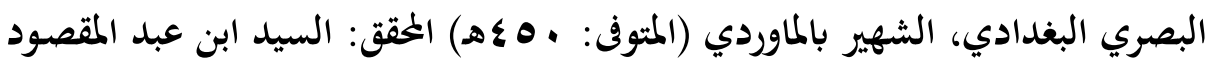
بن عبد الرحيم . ط : دار الكتب العلمية - بيروت / لبنان

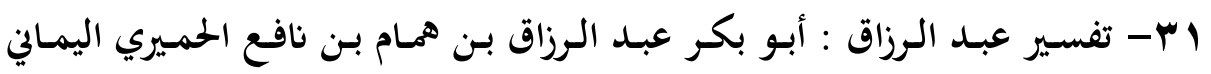

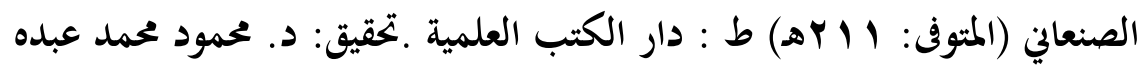

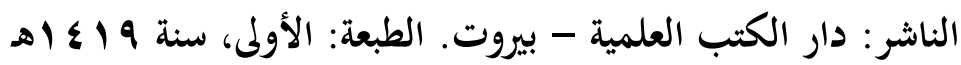

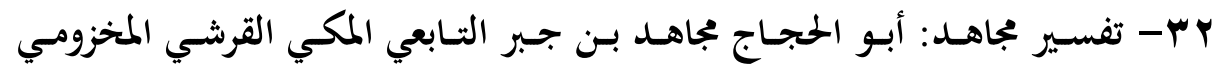

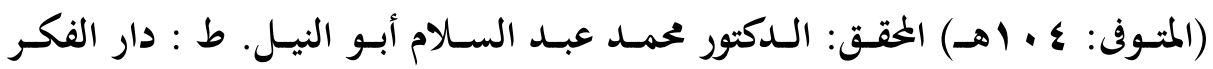

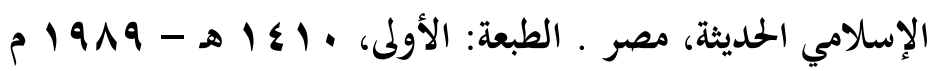
بس- تفسير مقاتل : أبو الحسس مقاتل بن سليمان بن بشير الأزدي البلخى (المتوفى: (ه) 0. الحققق: عبـد الله محمـود شـحاته. ط : دار إحيـاء الـتراث - بـيروت الطبعـة: الأولى ه ع ب- جامع بيان العلم وفضله لابن عبد البر : يوسف بن عبد البر النمري المتوفى سنة

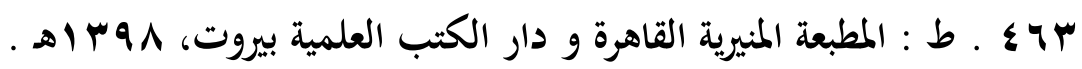

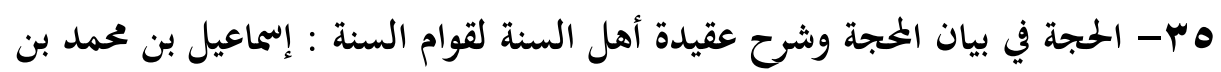

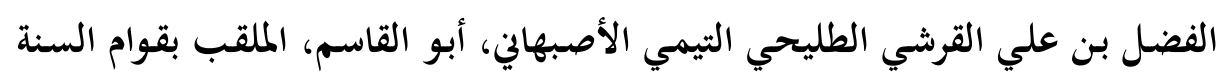
(المتوفى: هبهده) الخحقق: محمد بن ربيع بن هادي عمير المدخلي. ط : دار الراية -

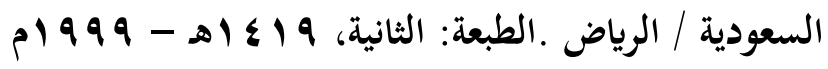


جا - حليـة الأوليـاء وطبقـات الأصـفياء لأبي نعـيم : أحمـل بـن عبـد الله بـن أحمـد بـن إسحاق بن موسى بن مهران الأصبهاين (المتوفى: · بعهـ) ط: السعادة - بجوار محافظة

مصر، ع 9 \&

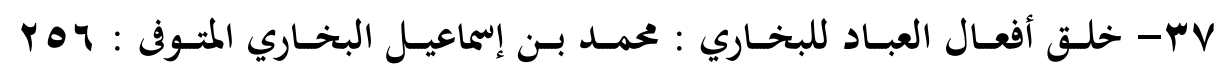
هـ .الحقـق : فهـد بـن سـليمان الفهيـد . ط : دار أطلس الخخسراء ـ الطبعـة : الأولى ، \&.. O

^ب- اللدر المصسون في علـوم الكتـاب المكنسون للسـمين الحلبي: أبـو العبـاس، ثـهاب

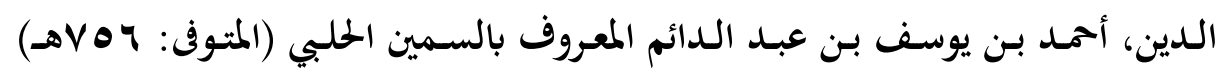
المحقق: الدكتور أحمد محمد الخراط . ط : دار القلم، دمشق يوست بـ ه س- الدر المنثور في التفسير بالماثور للسيوطي : عبد الرحمن بن أبي بكر السيوطي ت:

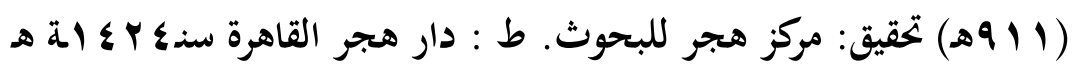
• ع- الدعاء للطبراين : سـليمان بـن أحمد بـن أيسوب بـن مطير اللخمي الثـامي، أبو

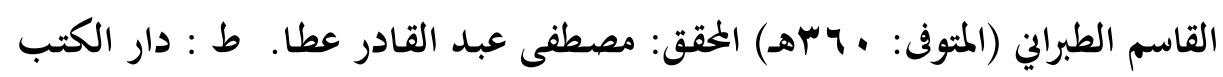

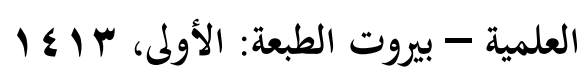

اع - الرد على الجهميـة للـدارمي : أبـو سعيد عثمـان بـن سعيد بـن خالد بـن سعيد

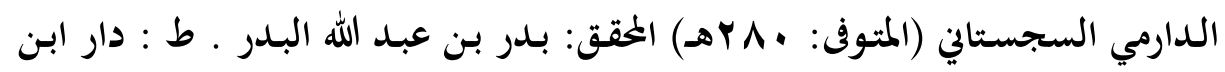

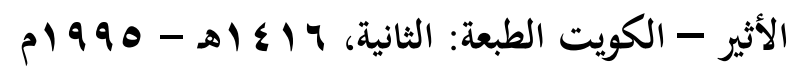

ץ ع- روح البيان : إسماعيل حقي بن مصطفى الإستانبولي الحنفي الحلوتي ، المولى أبو

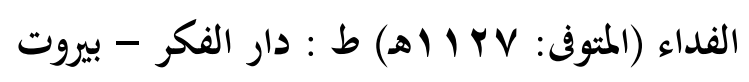

بع - زاد المسير في علم التفسير لابن الجوزي : جمال الدين أبو الفرج عبد الرحمن بن علي بن محمد الجوزي (المتوفى: 9 ههـ) المحقق: عبد الرزاق المهدي. ط : دار الكتاب

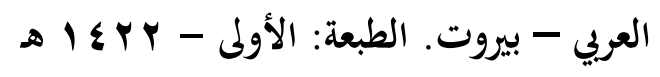


ع §- سنن أبي داود : سليمان بن الأشعث بن إسحاق بن بشير بن شداد بن عمرو

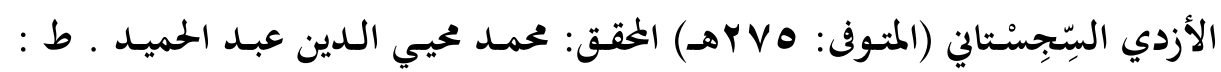

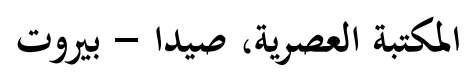

ه ـ - سنن الترمذي : محمد بن عيسى بن سَوْرة بن موسى بن الضحاك، الترمذي، أبو

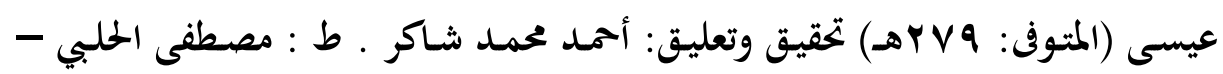

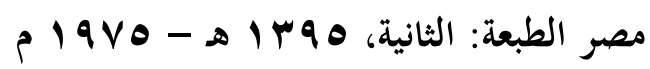

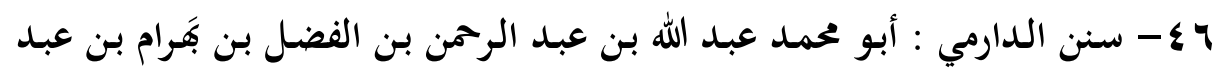

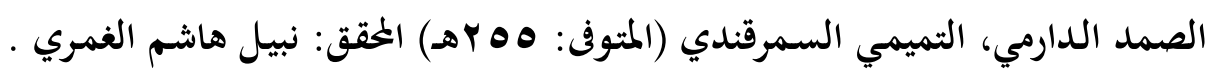

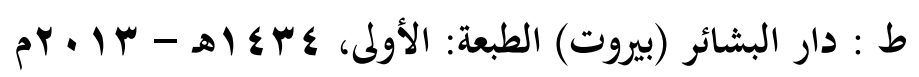

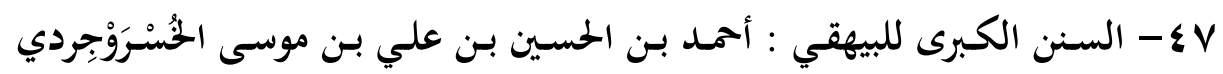

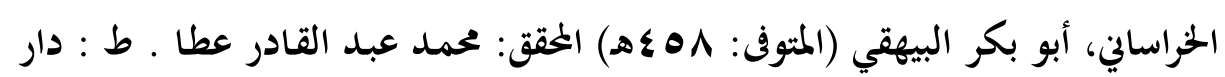

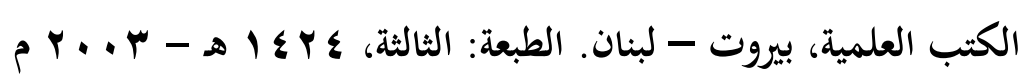

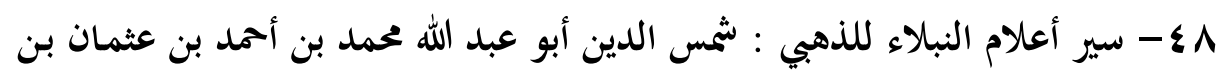

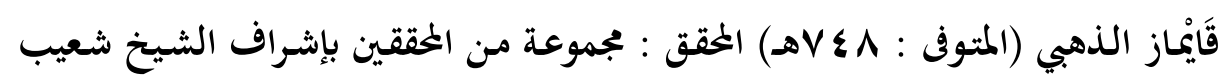

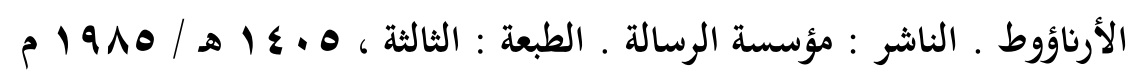

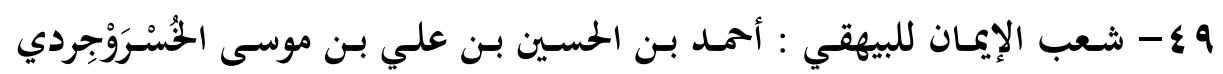

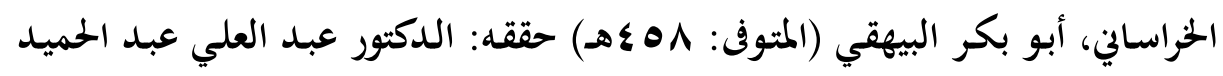

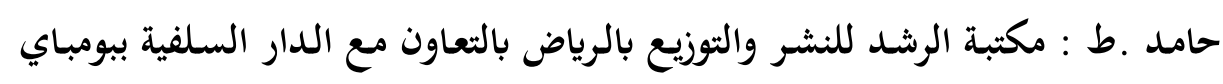

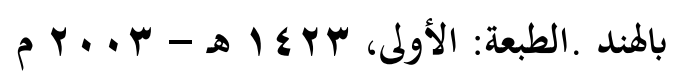
• ه- صحيح ابـن حبـان : محمـد بـن حبـان بـن أحمـد بـن حبـان بـن معـاذ بـن مَعْبـدَ،

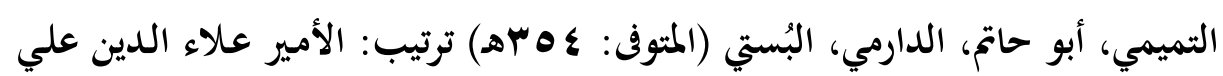

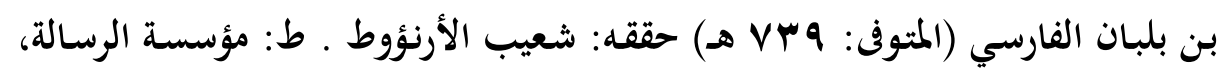
بيروت .

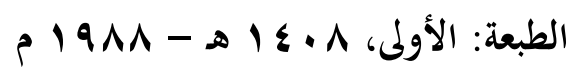


اه- صحيح البخاري . تحقيق : د. مصطفى ديب البغا . ط : دار ابن كثير ، اليمامة

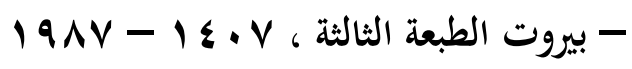

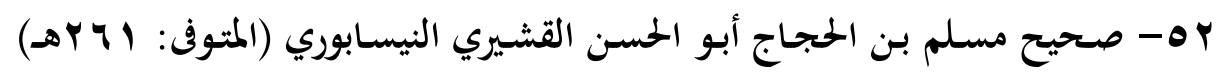

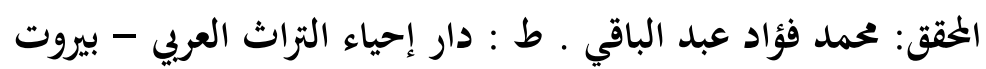
به- الطبقات الكبرى لابن سعد : أبو عبد الله محمد بن سعد بن منيع الهاشي بالولاء، البصري، البغدادي (المتوفى: • س بهـ) تحقيق: محمد عبد القادر عطا. ط : دار الكتب

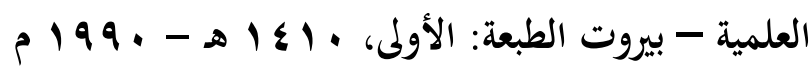
عه- العواصم والقواصم في الذب عن سنة أبي القاسم لابن الوزير : عحمد بن إبراهيم

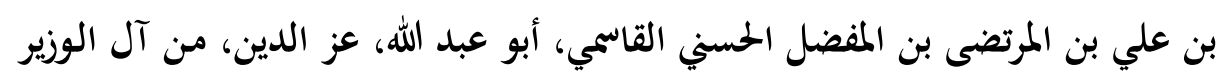

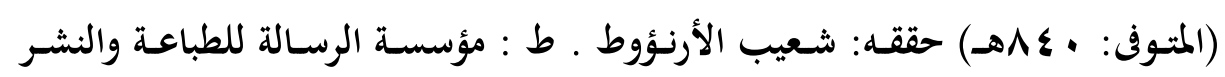

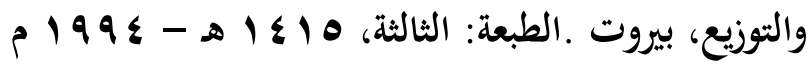
هـ - الفصول في الأصول للجصاص: أحمد بن علي أبو بكر الرازي الجصحاص الحنفي

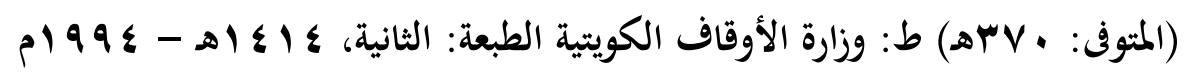
جه - فضائل الخلفاء لأبي نعيم : أحمد بـن عبد الله بن أحمد بـن إسحاق بن موسى بـن

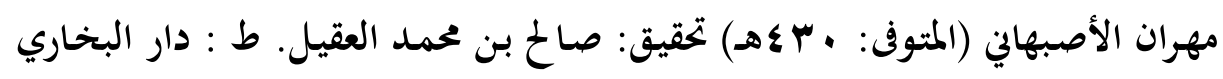

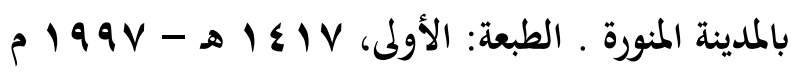

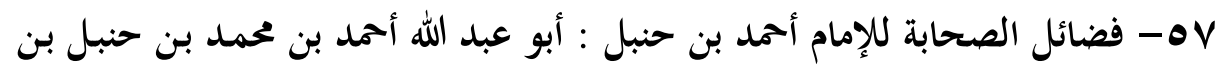
هـلال بـن أسـد الشـيباني (المتـوفى: اع بهـ) المحقق: د. وصسي الله محمـد عبـاس . ط :

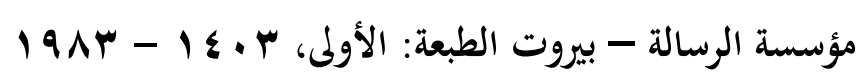

Aه - فوائد تمام : أبو القاسم تمام بن ححمد بن عبد الله بن جعفر بن عبد الله بن الجنيد البجلي الرازي ثم الدمشقي (المتوفى: ع إعه) المحقق: حمدي عبد الججيد السلفي. ط :

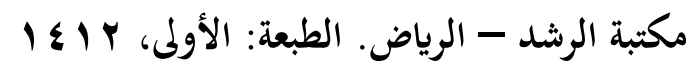


9ه- المجالسـة وجـواهر العلم للـدينوري: أبـو بكر أمـد بـن مـروان الدينوري المـالكي المتوفى سنة : بrسه المحقق : أبو عبيدة مشهور بن حسن آل سلمان ط : جمعية التربية

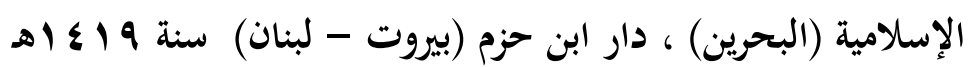

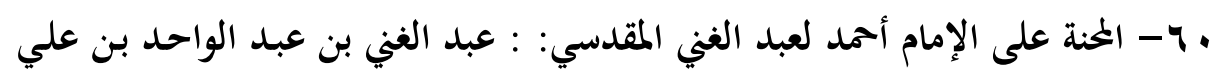

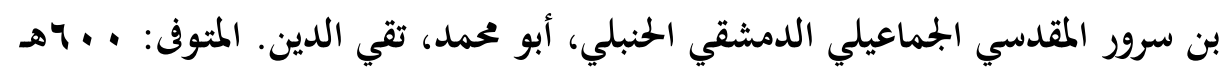

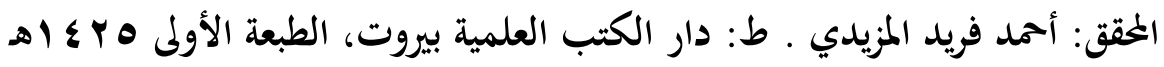

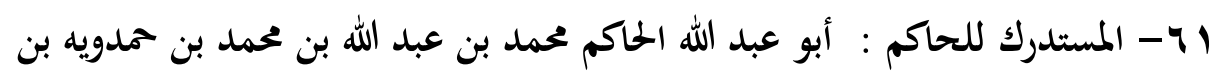

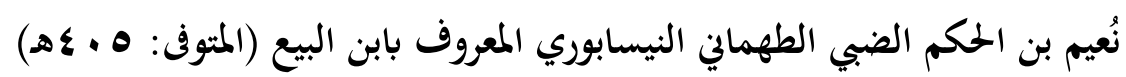

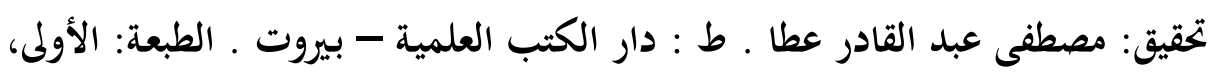
$199 .-1 \leqslant 11$ ץ צ- مسند ابن أبي شيبة : أبو بكر بـن أبي شيبة، عبد الله بـ محمد بـن إبراهيم بـن

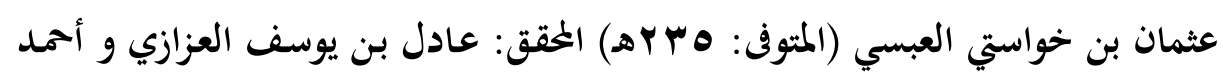

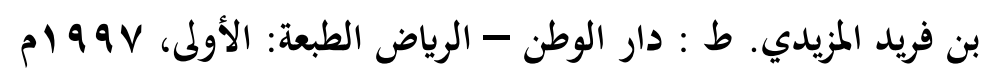

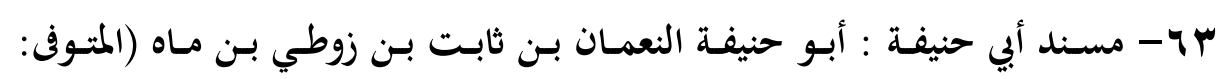

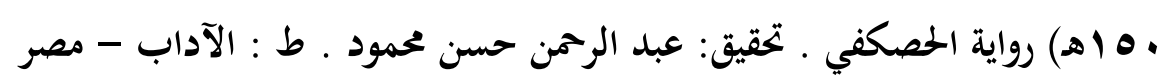

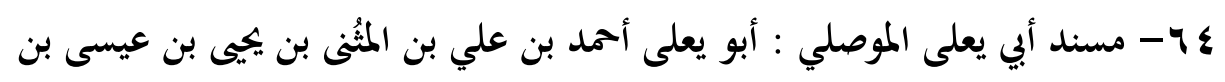

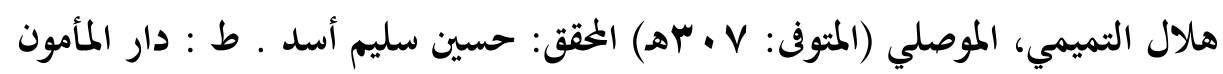

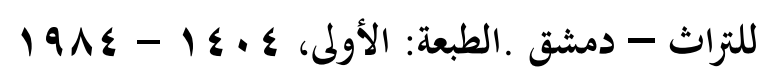

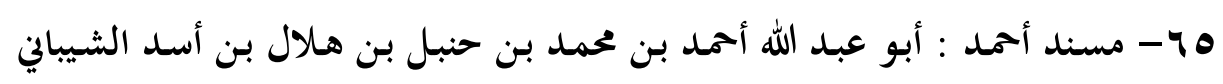

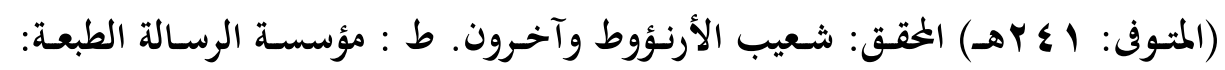

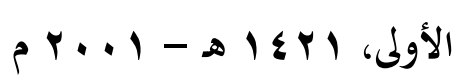

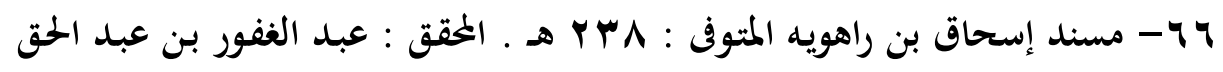

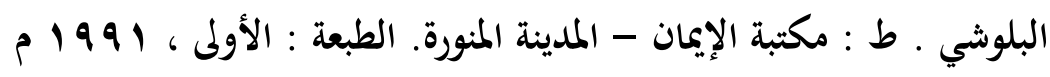


7V

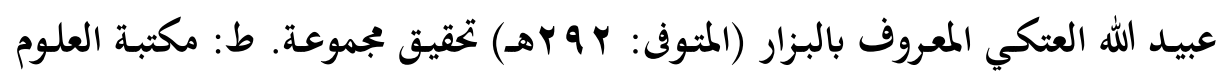

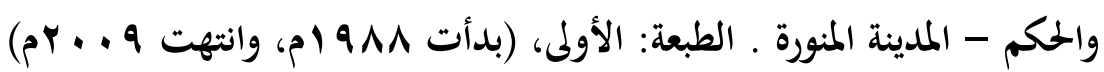

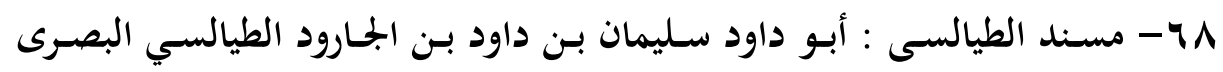

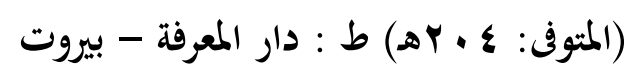
9 7- مسند الفردوس للديلمى (الفردوس بمأثور الخطاب للديلمى: شيرويه بن شهردار بن شيرو يه بن فناخسرو، أبو شجاع الديلميّ الممذابي (المتوفى: 9 ، 0هـ) المحقق:

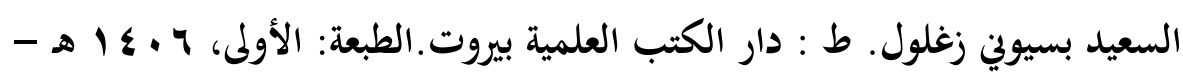
ค) $9 \wedge 7$ -V.

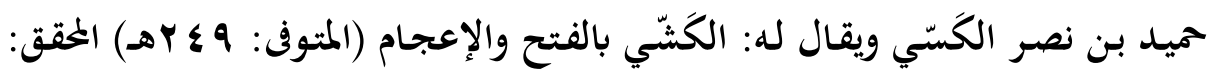

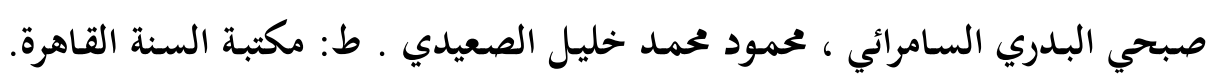

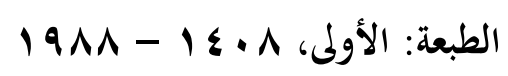

-VI

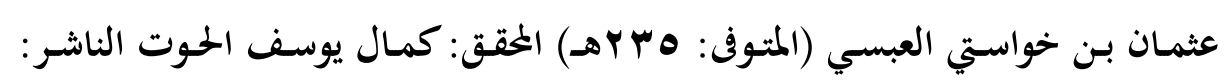

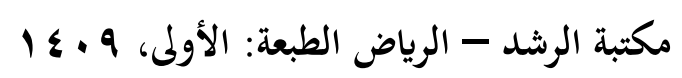

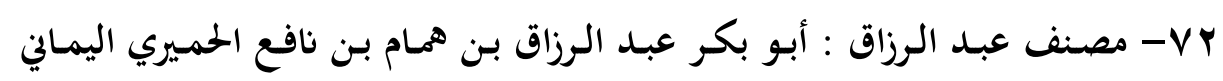

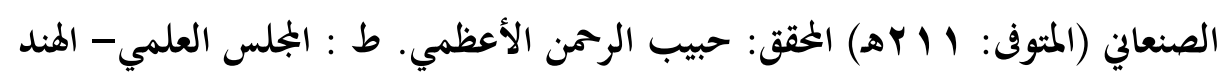

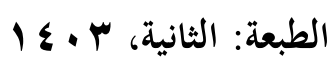

الب - معالم أصول الدين للرازي : أبو عبد الله محمد بـن عمر بـن الحسسن بـن الحسبين

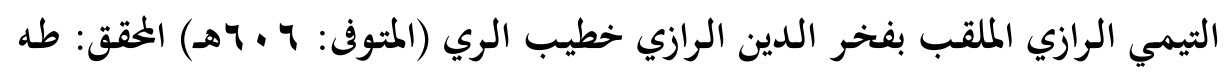

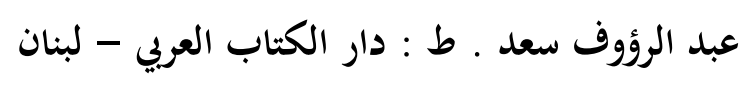

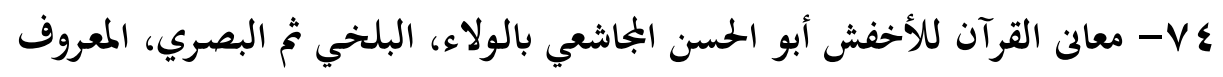

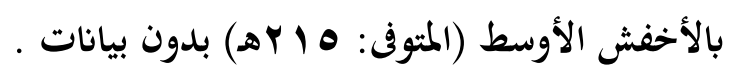


ه - معاني القرآن وإعرابه للزجاج : إبراهيم بن السري بن سهل، أبو إسحاق الزجاج

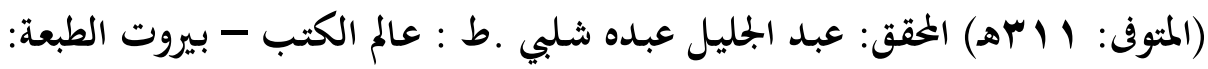

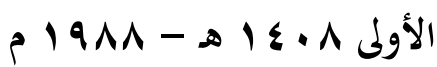
7 V - المعجم الأوسط للطبراني : سليمان بن أحمد بن أيوب بن مطير اللخمي الثـامي،

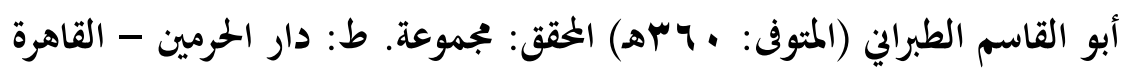

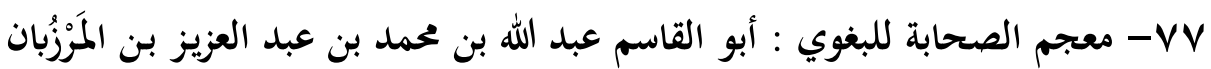

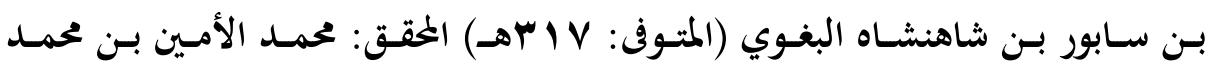

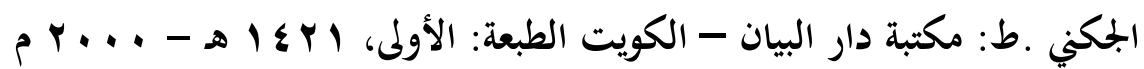
-VA

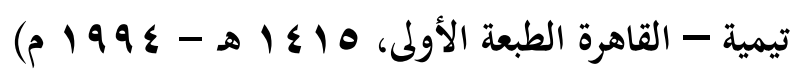

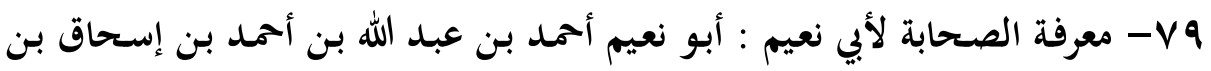

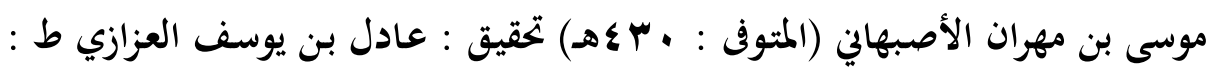

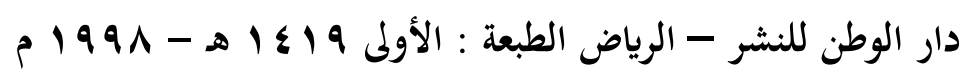

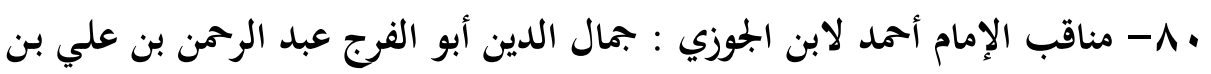

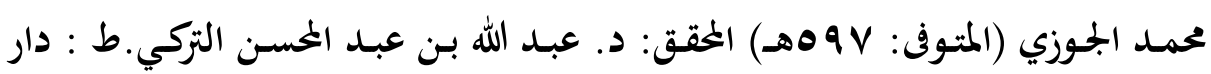

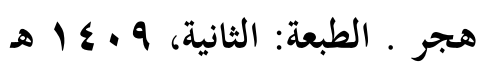
1

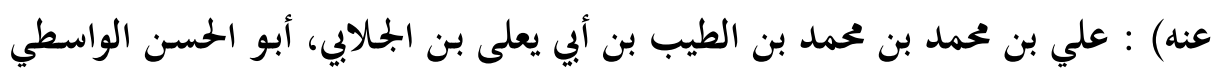

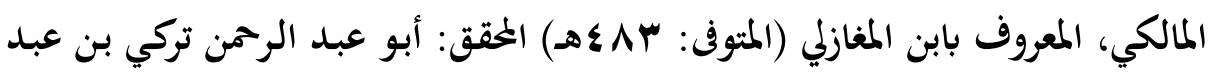

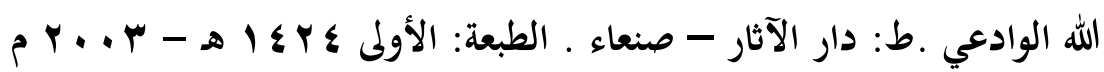

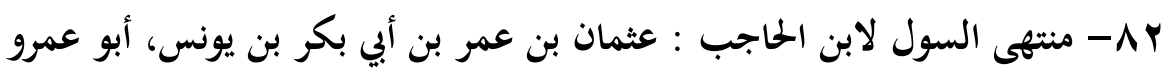

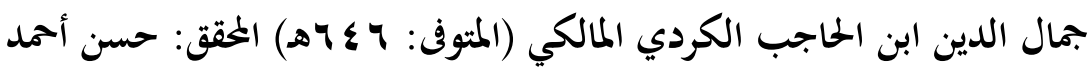

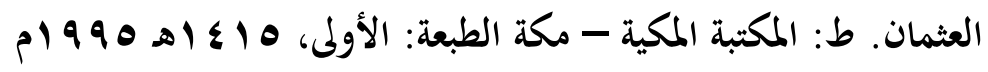


بر- المنخول (المنخول مـن تعليقات الأصـول) للعزالي : أبو حامـد محمـد بـن محمد

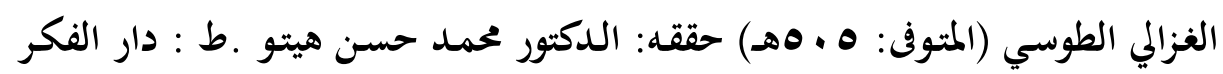

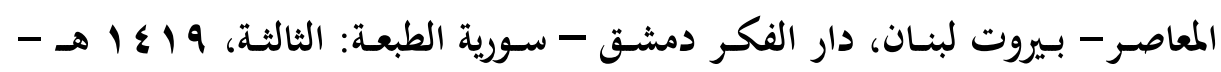
? 1991 ع - نزهة الأعين النواظر لابن الجوزي : جمال الدين أبو الفرج عبد الرحمن بن علي

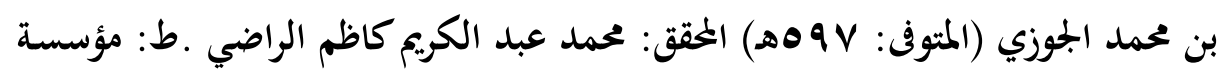

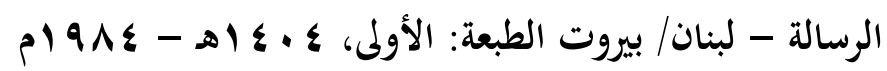

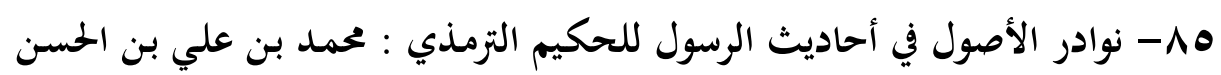

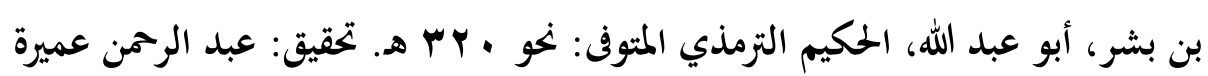

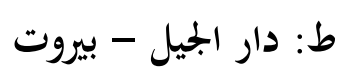
جی - المداية المى بلوغ النهاية للقيرواين: أبو محمد مكي بن أبي طالب حَّموش بن محمد

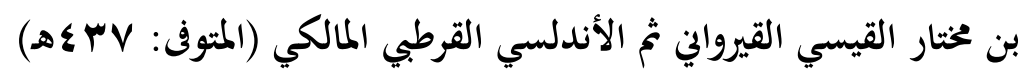

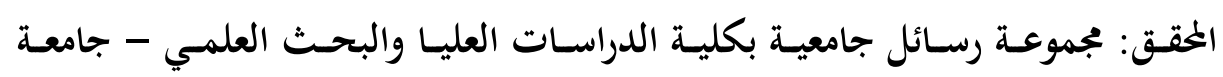

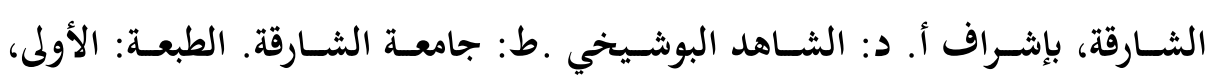

$$
\text { p r..人 - ه l }<r q
$$

- الوسيط للواحدي ( الوسيط في تفسير القرآن الججيد) أبو الحسن علي بن أحمد بن

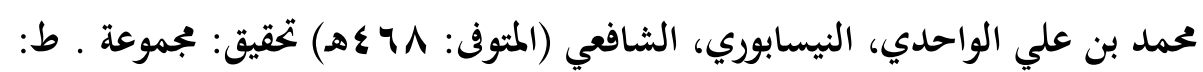

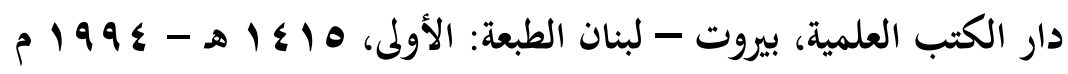

